UNIVERSIDADE DE SÃO PAULO

FACULDADE DE FILOSOFIA, LETRAS E CIÊNCIAS HUMANAS

DEPARTAMENTO DE LETRAS CLÁSSICAS E VERNÁCULAS

PROGRAMA DE PÓS-GRADUAÇÃO EM FILOLOGIA E LÍNGUA PORTUGUESA

Fernanda Alvarenga Teles

\title{
O sistema de normas e valores dos Grupos Escolares paulistas: a naturalização da ênclise
}

Versão corrigida 
UNIVERSIDADE DE SÃO PAULO

FACULDADE DE FILOSOFIA, LETRAS E CIÊNCIAS HUMANAS

DEPARTAMENTO DE LETRAS CLÁSSICAS E VERNÁCULAS

PROGRAMA DE PÓS-GRADUAÇÃO EM FILOLOGIA E LÍNGUA PORTUGUESA

\title{
O sistema de normas e valores dos Grupos Escolares paulistas: a naturalização da ênclise
}

\author{
Fernanda Alvarenga Teles
}

\begin{abstract}
Dissertação apresentada ao Programa de Pós-Graduação em Filologia e Língua Portuguesa do Departamento de Letras Clássicas e Vernáculas da Faculdade de Filosofia, Letras e Ciências Humanas da Universidade de São Paulo, para a obtenção do título de Mestre em Letras

Versão revisada e corrigida pelo autor, com a anuência de seu orientador.
\end{abstract}

Orientadora: Profa. Dra. Marilza de Oliveira

São Paulo

2014 
À Marilza, por sua extrema dedicação, pleno respeito e verdadeira contribuição à História Social da Língua Portuguesa. 


\section{Agradecimentos}

A Deus, por me permitir alcançar essa eterna alegria que nenhuma angústia da vida material é capaz de perturbar.

À Marilza, pela sua integral dedicação à pesquisa, fascínio pela evolução deste trabalho e suporte nos meus momentos mais desesperadores. Por se manter lado a lado nos entraves da busca pelo corpus e, principalmente, por ter transformado minha vida ao me realocar do interior para o verdadeiro posicionamento diante do mundo. Professora e orientadora por excelência.

Aos meus inesquecíveis pais, Vera e Vilmar, pelo fiel e incondicional amor de sempre, sem o qual, eu me perderia. Por contarem nos dedos os dias para me ver chegar, por me oferecerem momentos preciosos a cada instante em que estamos juntos e por compreenderem que minha escolha profissional me trouxe e me traz muita felicidade e satisfação pessoal. Toda nossa convivência de ontem e de hoje me torna mais forte.

Aos meus irmãos, Vanessa e Aluísio, por anularem qualquer diferença que exista entre nós, por me defenderem com unhas e dentes em todas as situações necessárias e por acreditarem, lealmente, na pessoa que sou. Quem tem irmão sabe do que estou falando.

À minha avó Albertina, por todo o amor e atenção dedicados aos seus filhos e netos, pois mesmo diante de todas as dificuldades, jamais deixou de estar disponível para qualquer um de nós que a procurasse. Obrigada pela força de sempre, por suas sinceras orações e pensamentos positivos sintonizados diariamente.

Aos queridos Rô e Beto, por terem me adotado como filha, amiga e irmã, pelo companheirismo e cumplicidade construídos dia a dia, pelas risadas memoráveis de detalhes que só nós merecemos saber. Enfim, pela família que vocês me deram e me ajudaram a construir mesmo longe de casa.

Aos meus tios, Vera e Beto, por cada bom momento compartilhado em inúmeros sábados, domingos, feriados... todos sempre recheados de muitas risadas e de uma 
ternura que irriga meus olhos. Agradeço também os acolhimentos, de diversas ordens, nas segundas, terças, quartas, quintas e sextas. Obrigada pela família que me oferecem.

Ao inestimável Francisco, inicialmente, pela revisão deste trabalho e pela paciência de me acalmar sempre que o desespero acadêmico me atingia. Pelas eternas ligações de apoio, consolo e motivação, pelas gargalhas intermináveis sobre nossas memórias repletas de tudo que já passamos juntos desde nossa graduação. Amigo de todas as horas, meu companheiro fiel, muito obrigada por ser a amizade mais verdadeira que possuo hoje.

À querida Rosa Maria, por compartilharmos um lar e momentos de muita alegria, pelo suporte e incentivo diários, mas, sobretudo, por passar junto comigo a tensão do final do trabalho e me aguentar durante todo esse período.

À Daniela Herrera Flores, por ser mais do que uma aluna dedicada, por ser uma amiga preocupada com os sentimentos envolvidos na finalização deste mestrado. Serei eternamente grata por todo o apoio que me deu em dias de grandes angústias, você foi essencial para que eu terminasse esta etapa de cabeça erguida, obrigada por acreditar em mim e na minha capacidade. Eterna gratidão.

Ao predileto Penha, por colorir minhas ideias apenas com seu sorriso, por segurar todas as minhas pontas nesses últimos meses e por fazer de mim uma pessoa muito mais feliz. Obrigada por todos os momentos de atenção e carinho que tem me dado, que essas lembranças sejam eternizadas.

Às doces Érica, Giovanna e Priscilla, pelas leituras atentas das últimas versões desta dissertação, pelas agradáveis companhias em nossos encontros, pela ajuda, estímulo e encorajamento de sempre.

À Hosana e ao Hélcius, por terem gentilmente aceitado participar da minha banca de qualificação e por terem contribuído com preciosas e engajadas sugestões para o desenvolvimento e finalização deste trabalho. 
Aos professores Hélcius e Lília, por fazerem parte da minha defesa de mestrado não apenas como banca, mas como torcida para que este trabalho fosse finalizado com sucesso. Obrigada pela paciência e atenção dedicadas à leitura atenta dos pormenores implícitos e explícitos desta dissertação.

Ao Arquivo Público do Estado de São Paulo, por acolher tão satisfatoriamente a curiosidade de todo e qualquer pesquisador que, ao agarrar sua investigação, mergulha no universo dos documentos ali guardados. 
Estavam no engenho passando uns tempos umas parentas do Recife. Era uma gente que não tirava as meias da manhã à noite, falava francês uma com a outra, só conversava negócios de teatro: o tenor tal, que belo homem!, a artista fulana, que chique! As filhas do tio João, quando chegavam no engenho, revolucionavam os hábitos pacatos da casa-grande. Só viviam trancadas nos banhos mornos, dando trabalho às negras, lendo romances nas cadeiras de balanço. [...] E até em nós esta influência se exercia: não tirávamos os sapatos dos pés, por causa da gente do Recife. [...] Maria Clara, mais velha do que eu, andava comigo pela horta. [...] Ela me contava as histórias de suas viagens de mar, pintava-me o vapor, os camarotes, o tombadilho e o mar batendo no olho de vidro das vigias.

José Lins do Rego. Menino de Engenho. 1932. 


\section{Resumo}

Grandes transformações sociais, econômicas e políticas ocorriam no Brasil republicano do final do século XIX. Nesse contexto, forças sócio-políticas operavam na proposta de civilização do país que se apoiava na difusão das instituições de ensino como estratégia para se equiparar à modernização e ao progresso dos países europeus. Assim, os Grupos Escolares foram criados em contraposição às escolas isoladas do período monárquico, inovando no cenário brasileiro com a implantação do ensino graduado e com o método intuitivo, servindo de propaganda ao novo governo instaurado. Alguns estudos têm mostrado que, dentro desse panorama da virada do século XIX, uma mudança na colocação pronominal em orações infinitivas preposicionadas se implanta no Português Brasileiro, o qual se distanciava do padrão lusitano e do uso vernacular da época. Considerando o crescimento da próclise do vernáculo brasileiro (OLIVEIRA, 2013) e a ênclise majoritária dos intelectuais republicanos paulistas (SANTOS SILVA, 2012) nesse contexto sintático, este trabalho investigará se os Grupos Escolares Paulistas adotavam um único padrão linguístico quanto à posição do pronome em infinitivas preposicionadas. Para essa análise, serão estudados ofícios e relatórios escritos em 1902 e 1906 por diretores de 34 grupos e inspetores da educação do estado de São Paulo. Para uma boa análise qualitativa dos dados, será adotado o paradigma indiciário de Ginzburg (1989), juntamente a um estudo etnográfico dos grupos e de seu conteúdo programático que permitirá identificar o pano de fundo da difusão desse novo tipo de escola e entender a simbólica importância dessa instituição de ensino para a sociedade republicana. Dessa forma, será possível entrelaçar o ponto de vista linguístico com a sócio-história dos Grupos Escolares paulistas na virada do século XIX para o XX.

Palavras-chave: colocação pronominal, orações infinitivas preposicionadas, Grupos Escolares paulistas, imaginário republicano, História Social da Língua. 


\begin{abstract}
Significant social, economic and political changes took place in the Brazilian Republic in the end of $19^{\text {th }}$ century. In this context, socio-political forces operated in the civilization proposal of country supported in the dissemination of educational institutions as a strategy to match the modernization and progress of European countries. So School Groups were created in opposition to distant schools of the monarchy period, innovating in the Brazilian scenario with the implementation of graduate education and the intuitive method, serving as an advertisement of the new government. Some studies have shown that a change was implanted in the clitic placement in prepositional infinitive sentences in Brazilian Portuguese in the turn of $19^{\text {th }}$ century, which distanced from both the standard European Portuguese and the Brazilian vernacular use. Considering the increase of proclisis of Brazilian vernacular (OLIVEIRA, 2013) and the majority enclitic of republican intellectuals of São Paulo (SANTOS SILVA, 2012) in this syntactic context, this study will investigate if the School Groups of São Paulo adopted a single linguistic standard about the clitic placement in prepositional infinitive sentences. For this analysis, formal texts written in 1902 and 1906 by directors of 34 School Groups and education inspectors of São Paulo will be studied. For a satisfactory analysis, the evidential paradigm of Ginzburg (1898) will be adopted, along with an ethnographic study of School Groups and their curriculum that will identify the background of the propagation of this new kind of school and understand the symbolic matter of this educational institution for the republican society. So the linguistic point of view can be interlace with the socio-history of School Groups of São Paulo in the turn of $20^{\text {th }}$ century.
\end{abstract}

Keywords: clitic placement, prepositional infinitive verbs, School Groups of São Paulo, republican imaginary, Social History of Language. 


\section{SUMÁRIO}

Introdução. .01

Capítulo 1 - Escolas graduadas a serviço da ordem. .07

Introdução. .07

1. Alunos, eleitores e militantes em fornadas republicanas......................................11

2. Filosofia das escolas graduadas: a ordenação da ordem......................................15

$2.1 \mathrm{O}$ ensino em série: classificação e formatação....................................................16

2.2 Ordem militarizada: o grupo como batalhão escolar..........................................21

3. Visibilidade instaurada: a ordem em construção...............................................27

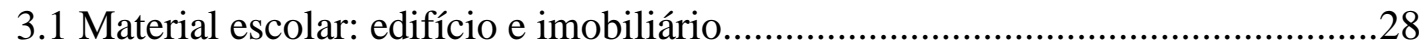

3.2 A pedagogia dos prêmios nos ajustes didáticos...................................................36

3.2.1 A classe docente: trabalho nos bastidores........................................................36

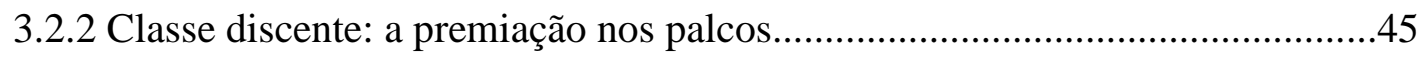

$3.3 \mathrm{O}$ arsenal da propaganda: exames e festas cívicas............................................48

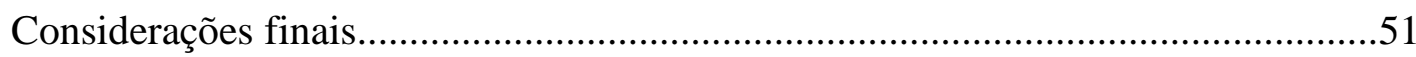

Capítulo 2 - Expansão dos Grupos Escolares: difusão da norma linguística....53

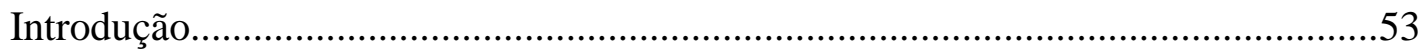

1. Contextualizando a análise linguística.........................................................57

2. O final do século XIX: os três modelos de colocação pronominal.....................64

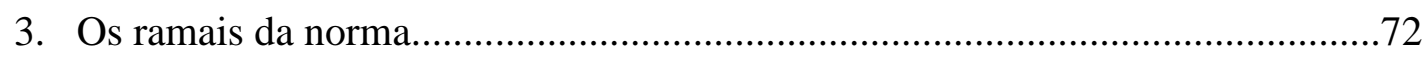

3.1 Preposições e pronomes: panorama geral..........................................................72

3.2 Expressões formulaicas e expressões abertas................................................74

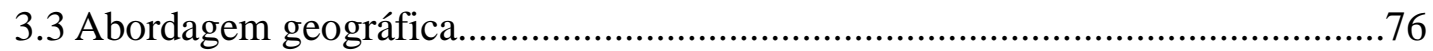

3.3.1 Modelo português: ênclise apenas com a preposição $a$..................................76

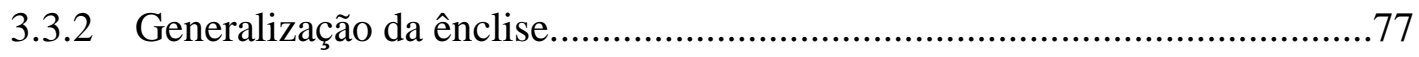

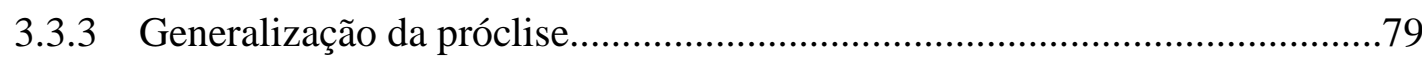

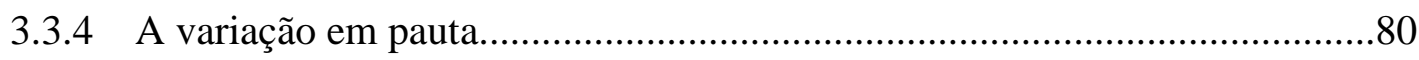

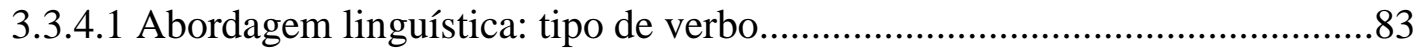




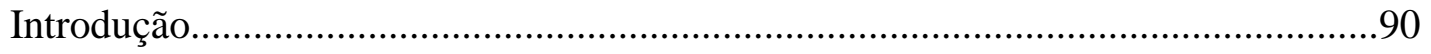

1. Estrutura classificatória: equilíbrio físico e mental evolucionista.......................91

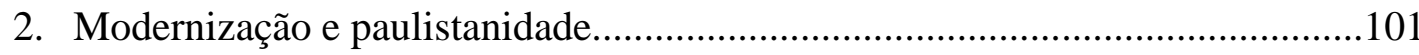

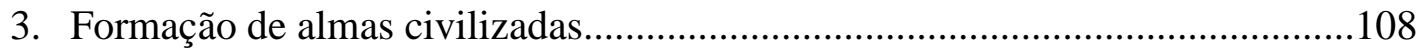

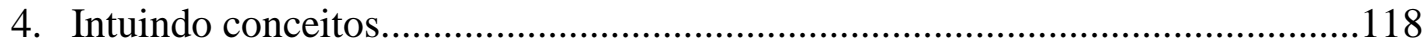

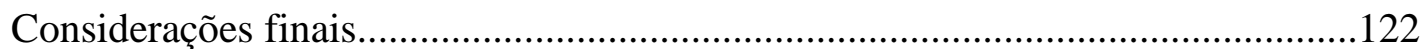

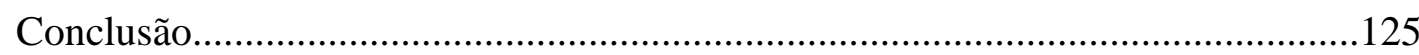

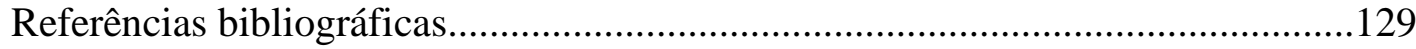

Anexos 


\section{Introdução}

O contato com o elemento civilizado retratado no romance Menino de Engenho (1932), cujo trecho foi reproduzido na epígrafe deste trabalho, evidencia a forma como os conceitos de civilização e modernização eram inseridos em contextos afastados do núcleo citadino. Na fazenda Santa Rosa, o impacto se dava não apenas com os hábitos, mas também no uso do francês, nas idas ao teatro e nas viagens de navio.

A correlação entre língua e civilização infere claras distinções que marcam a oposição entre área urbana e zona rural, realçando a importância que tal temática possuía na época. Assim, a crítica velada pela obra revela a autoridade que o processo civilizatório obtinha em um período marcado por grandes transformações sociais, econômicas, políticas e linguísticas: a Primeira República.

Nesse contexto, um jogo de forças sociopolíticas operava na proposta de civilização do país que se apoiava na difusão das instituições de ensino como importante vetor na modernização brasileira desejada. É assim que, no âmbito educacional, um sistema de ensino unificado nacionalmente é reconstruído com foco na expansão de escolas a fim de garantir a visibilidade às iniciativas governamentais.

A reforma do ensino passou inicialmente pela Escola Normal, pela instauração da Escola-Modelo anexa, até se consagrar na abertura de escolas primárias, com o lançamento dos Grupos Escolares como autêntica criação republicana, a qual serviu de esteio para as propagandas do novo governo instaurado. Delegada aos estados a provisão do ensino público primário, São Paulo, logrando sua hegemonia política e econômica, iniciou tal processo em 1893. (SOUZA, 2005).

Como contraponto às escolas isoladas do período monárquico, os grupos inovam no cenário brasileiro com a implantação das escolas graduadas na tentativa de se alinhar 
ao progresso dos países europeus. Com isso, os alunos passam a ser divididos em séries determinadas de acordo com a idade, nível de aprendizagem e estágio de conhecimento, além da separação em seções feminina e masculina.

Apostando na seriação do ensino, o método intuitivo é eleito como ferramenta pedagógica capaz de substituir a aprendizagem do governo monárquico centrada na memorização e repetição de conteúdos. Essa nova metodologia valoriza a intuição, permitindo ao aluno assimilar, por meio da observação e dos sentidos, todo e qualquer conhecimento, além de pressupor o uso de salas e objetos adequados para o desenvolvimento desse modelo. (idem).

O imaginário da República, portanto, coroa os Grupos Escolares como a concretização da modernidade trazida pelo novo regime político, os quais tinham como função formar cidadãos republicanos. Nesse sentido, a escola tinha a missão de difundir valores políticos entre os alunos que os permitissem perceber as virtudes da organização social alcançada no momento. (VALDEMARIN, 2004).

Dentro desse panorama da virada do século XIX, a formação do Português Brasileiro também adquire posição privilegiada. Em meio ao borbulhar de mudanças socioeconômicas e políticas no país, um conjunto de discussões linguísticas instaura um processo de reformulação das normas gramaticais, cuja variedade brasileira já apontava diferenças estruturais com relação à portuguesa (TARALLO, 1993), entre as quais se destaca a colocação pronominal. A gramática portuguesa é, no geral, tendente à ênclise e a variedade brasileira vai consolidando a próclise.

Alguns estudos apontam que, no final do século XIX, um processo de mudança na posição do clítico em orações infinitivas preposicionadas se implanta na modalidade culta do Português Brasileiro, o qual se distancia tanto do padrão lusitano como do uso vernacular da época. (PAGOTTO, 2011; OLIVEIRA, 2011; SANTOS SILVA, 2012). 
Em contraposição ao uso vernacular, a escrita brasileira do final do século XIX opta pelo emprego massivo da ênclise. O reflexo dessa antinomia tem sido associado à proposta de civilização do país sustentada pelas elites, camada social que teria buscado no Português Europeu Moderno um modelo de língua inacessível às classes mais baixas - marcada pela ênclise pronominal, o que resultaria em uma unidade normativa com Portugal. (PAGOTTO, 1998).

A análise da colocação pronominal no contexto de infinitivas preposicionadas em textos portugueses e brasileiros, ao longo do século, evidenciou, no entanto, que a ênclise portuguesa é diferente daquela realizada pelos brasileiros. Naquela variedade, a ênclise se restringe ao contexto da preposição $a$ e nesta é indiferente ao tipo de preposição regente. (OLIVEIRA, 2011; 2013). Além disso, os intelectuais republicanos extrapolam o emprego da ênclise, de modo a torná-la categórica em todos os contextos. (SANTOS SILVA, 2012).

Tendo em vista o crescimento da posição proclítica do vernáculo brasileiro (OLIVEIRA, 2013) e a gramática enclítica dos intelectuais republicanos paulistas (SANTOS SILVA, 2012), surge a questão se os Grupos Escolares Paulistas adotavam um único padrão linguístico quanto à colocação pronominal em orações com verbos infinitivos regidos por preposição.

Por serem apontados como representantes legítimos da Primeira República e por ganharem visibilidade ao servir de bandeira para o novo governo, os grupos, por hipótese, adotariam a ênclise como padrão linguístico seguindo os intelectuais republicanos que a utilizavam como marcador de diferenças sociais.

Essa hipótese está alicerçada na ideia de que sempre que uma diferença linguística se torna distintiva, os termos dessa distinção se baseiam nas relações sociais que os cercam, ou seja, tal diferença pode estar a serviço de distinções sociais. 
(ECKERT, 2003). Assim, a colocação pronominal deve ser objeto de investigação na prática estilística, cujo significado não é específico e fixo, mas sim (re)construído socialmente.

É nesse processo de (re)construção de significado que os falantes atribuem sentido a recursos estilísticos disponíveis em seu determinado contexto social e os selecionam para a sua própria prática. Algumas escolhas linguísticas indicam atitudes, posturas e atividades associadas a categoriais sociais, as quais se apóiam muito em estilo, fundamental, portanto, na criação de uma rede de significados interligados socialmente (idem).

Portanto, torna-se necessário considerar o dado linguístico juntamente com os elementos externos ligados à sua produção. Para isso, o âmbito linguístico será correlacionado com outras estratégias escolares na produção de disposições corporais e habilidades sociais específicas (PEROSA, 2006) e com a sócio-história dos Grupos Escolares paulistas.

A colocação pronominal em orações infinitivas preposicionadas atua como um paradigma indiciário, na medida em que pequenos sinais podem revelar modelos diferentes, pois um método focado na observação e análise de detalhes, a princípio insignificantes, podem ser capazes de revelar efetivos indícios para uma adequada interpretação qualitativa. (GINZBURG, 1989). Assim será possível interpretar as pistas deixadas na realidade estudada, às vezes, inatingível pelo observador.

A partir de um estudo etnográfico dos grupos e de seu conteúdo programático, pretende-se identificar o verdadeiro pano de fundo da difusão desse novo tipo de escola, representante da propaganda do governo republicano. Se essa etnografia ajuda a compreender o modo de interiorização do imaginário republicano, a sócio-história dos Grupos Escolares deflagra os motivos da falha na implementação do método intuitivo, a 
grande inovação do ensino republicano, em oposição à memorização e repetição do método usado na escola do período monárquico.

Para essa análise, serão estudados textos oficiais de estilo formal de elaboração, compostos por ofícios e relatórios produzidos em 1902 e 1906 por diretores dos Grupos Escolares e inspetores da educação do estado de São Paulo. Produzidos no âmbito de 36 grupos da cidade de São Paulo e do interior paulista, esses documentos se encontram disponíveis no Arquivo Público do Estado de São Paulo.

$\mathrm{Na}$ listagem completa dos nomes desses grupos ${ }^{1}$, podem-se perceber determinados agrupamentos. Alguns possuem nomes de políticos republicanos importantes da época, por exemplo, Grupo Escolar Jorge Tibiriçá (Bragança Paulista), Grupo Escolar Dr. Cesário Motta (Itu), Grupo Escolar Moraes Barros (Piracicaba), Grupo Escolar Dr. Bernardino de Campos (São Roque), dentre outros. Coronéis que, provavelmente, detinham o poder da cidade ou região, também dão nome a outros grupos, tais como, Grupo Escolar Cel. Vaz (Jaboticabal), Grupo Escolar Flaminio Ferreira (Limeira), Grupo Escolar Cel. Venâncio (Mogi Mirim), etc.

Certos grupos recebem apenas o nome da própria cidade ou bairro, como no caso de Campinas, Piracicaba, Ribeirão Preto, São José dos Campos, São Simão, Serra Negra, Tatuí, Taubaté e São Paulo. Além do Grupo Escolar Barão de Monte Santo, que recebe tal nome em homenagem ao doador do prédio onde funcionava a escola.

Os documentos que serão analisados são sempre endereçados ao secretário do interior para prestar contas sobre o movimento dos grupos, porém, pelos carimbos e assinaturas, verifica-se que as respostas advinham da Sub-diretoria do Interior, cuja hierarquia dos chefes-interinos da $1^{\mathrm{a}}, 2^{\mathrm{a}}$ e $3^{\mathrm{a}}$ seções era considerada de acordo com a gravidade do problema apontado.

\footnotetext{
${ }^{1}$ Listagem exposta na tabela 1 dos anexos.
} 
Os ofícios enviavam informações de várias ordens, desde simples avisos até sugestões de nomeação de docentes. Já os relatórios detalhavam o movimento de alunos e de professores durante o ano, além de referenciar comemorações cívicas, exposições de trabalhos, visitas de autoridades, falta de professores e as condições da estrutura física do grupo.

Além disso, serão analisadas provas escolares datadas de 1896 e 1900. Embora sejam de períodos diferentes dos documentos, elas também foram produzidas no período de instalação dos grupos. ${ }^{2}$

Para alcançar a proposta dessa investigação, o Capítulo 1 focalizará a história dos Grupos Escolares (re)caracterizada pelos ofícios e relatórios analisados, a qual, tangenciada à bibliografia específica do assunto, fornecerá elementos para o entendimento da simbólica importância dessa instituição de ensino primário para a sociedade republicana do final do século XIX.

Já o Capítulo 2 abarcará as ocorrências linguísticas encontradas, identificando o padrão, ou os padrões, adotados pelos Grupos Escolares paulistas com relação à colocação pronominal em infinitivas preposicionadas a partir de critérios linguísticos e extralinguísticos.

No Capítulo 3, o estudo do conteúdo programático dos grupos, acessível por meio da análise das avaliações escolares, sonda as estratégias por meio das quais se infunde nos alunos o sistema de normas e valores republicanos. A partir disso, as conclusões são esboçadas, procurando entrelaçar o ponto de vista linguístico aos valores culturais do conteúdo programático e sócio-história dos Grupos Escolares paulistas na virada do século XIX para o XX.

\footnotetext{
2 Não foram encontradas avaliações produzidas no período de 1902 a 1906, nem documentos de 1896 e 1900 .
} 


\section{Capítulo 1 - Escolas graduadas a serviço da ordem}

\section{Introdução}

Nos caminhos que a educação pública brasileira percorreu, destacamos as primeiras tentativas de se organizar o sistema educacional iniciadas em 1827, as quais se estenderam até os anos de 1890 com a iniciativa republicana de implantação dos Grupos Escolares, quando começa, de fato, a história da escola pública brasileira. (SAVIANI, 2005).

No final do Império, as discussões acerca da Instrução Pública aliada a outros temas emergentes da época, como a abolição da escravatura e o consequente incentivo à imigração, a industrialização, a reforma eleitoral e a questão política republicana, motivaram a busca pela construção de um sistema de ensino unificado nacionalmente.

Ao dar destaque para as escolas primárias, além de colocar a Instrução Pública sob a direção do governo central, seguindo os modelos dos países europeus, tal sistema seria capaz de ajudar a solucionar os demais problemas enfrentados pela sociedade da época.

A aposta foi grande, muitas fichas foram depositadas na Educação, já que, por meio dela, a própria atmosfera antecedente à República vendia a crença na possibilidade de um mundo mais igualitário, no qual, com o fim do trabalho escravo, muitas oportunidades de acesso à cidadania e formas de inclusão eram projetadas. (SCHWARCZ, 2012).

Porém, instaurada a República, o governo central não assumiu as rédeas da educação como sua responsabilidade e adotou uma descentralização justificada pela Constituição de 1891, cujo federalismo cedia grande autonomia aos estados, os quais 
teriam constituição e justiça próprias (ainda que subordinada a uma legislação unificada e à Justiça Federal), forças públicas armadas e capacidade de negociar empréstimos internacionais. (MATTOS, 2012).

No bojo dessa descentralização, os estados ficavam encarregados de instruir a população por meio da disseminação das escolas primárias e, pelo fato de São Paulo ocupar a posição de liderança nacional devido a sua hegemonia política e econômica alcançadas, respectivamente, pela condição de principal produtor e exportador de café e da política dos governadores, foi em seu território que o início da organização e instauração da Instrução Pública aconteceu.

Estruturada em torno de uma aristocracia ligada à produção e exportação cafeeira, a sociedade paulista exercia forte influência e domínio político a nível nacional, constituindo a força dominante da Primeira República. Dessa forma, a hegemonia paulista acelerou a ocupação de seu território por meio da construção da malha de ferrovias que transportaram o café pelo interior do estado, fato que elevou o crescimento demográfico:

De fato, o desenvolvimento paulista ficou condicionado a três fatores principais. Em primeiro lugar, à expansão cafeeira, que em sua marcha saía do vale do Paraíba e chegava ao Oeste Paulista, em finais dos anos 1850. Em segundo, à entrada da estrada de ferro que viabilizaria o transporte interno, então feito em lombo de burros, até o porto de Santos. Por fim, não há como deixar de mencionar o papel da imigração, que mudaria, como veremos, as feições, os dialetos, a culinária e os serviços públicos paulistas. (SCHWARCZ, 2012: 46).

A Oligarquia de São Paulo, a serviço do Partido Republicano Paulista, enfatizava a educação na tentativa de equiparar o Brasil ao progresso dos países europeus, pois acreditava que a repaginação nacional só seria alcançada pela promoção da educação popular. Paralelamente, a Constituição da República - diferente do Império 
que selecionava votantes pela renda - excluía os brasileiros analfabetos das eleições federais e estaduais. (MARCÍLIO, 2005).

Por mais que se tenha aumentado a quantidade de eleitores ( $2 \%$ em 1891), ao invés de amenizar o impacto do número reduzido deles no antigo regime, a medida surtiu um efeito adverso, pois ressaltou ainda mais a posição atrasada em que o Brasil se encontrava. ${ }^{3}$ A partir do momento em que a alfabetização foi eleita como pré-requisito para se obter cidadania política, a educação primária adquiriu posição central em inúmeros estados durante a Primeira República e mesmo não contando com a garantia da Constituição Federal.

Essa atmosfera republicana foi marcada por um entusiasmo pela educação e um otimismo pedagógico capazes de ditar os caminhos do progresso com a multiplicação de instituições escolares, indicando a verdadeira formação do homem brasileiro. (NAGLE, 1989). Contudo, nossa investigação sobre o assunto nos faz questionar se a verdadeira intenção era romper com o atraso escolar ou dar visibilidade ao novo governo por meio da abertura de escolas. Afinal, o otimismo se evapora devido ao fracasso, como se verá mais à frente, na aplicação do método intuitivo tal como proposto inicialmente.

No final do século XIX, grandes investimentos eram direcionados para o foco principal dos republicanos paulistas: a implantação de um sistema de ensino público moderno, com uma forte base administrativa e pedagógica. Antes mesmo da proclamação da república, os intelectuais paulistas já defendiam uma reforma do ensino para tentar eliminar o atraso existente. (MARCÍLIO, 2005).

A reforma começou pela Escola Normal em 1890, quando Caetano de Campos e Rangel Pestana, inspirados em países como Alemanha, Suíça e Estados Unidos, criara a Escola-Modelo, anexa à Escola Normal de São Paulo, como um órgão de estágio e

\footnotetext{
${ }^{3}$ Marilza de Oliveira, em comunicação pessoal, sugere que, além dos fatores sócio-históricos, a aquisição imperfeita do português como L2 pelos imigrantes deveria dar maior visibilidade ao analfabetismo.
} 
demonstração metodológica aos alunos normalistas egressos. Em 1892, uma reforma geral da Instrução Pública paulista é empreendida para difundir o ideário republicano de união entre progresso e educação popular, priorizando o ensino primário.

Fomentou-se, assim, um sistema educacional público desde o ensino primário e secundário à Escola Normal e ao superior, incluindo a criação do jardim-de-infância e do Ginásio do Estado. Vale destacar também que, em 1892, foi instituída a Secretaria do Interior, ${ }^{4}$ a qual ficou incumbida da gestão do sistema educacional e da Instrução Pública, cuja responsabilidade era administrar os serviços do ensino primário, secundário, superior, especial e profissional, público e particular, pela estatística, Arquivo e Diário Oficial, bibliotecas, museus e associações literárias.

Para sistematizar os assuntos educacionais do estado, a Instrução Pública foi reorganizada com a criação da Secretaria Geral da Instrução Pública, subordinada a um diretor geral, e dividida em três seções: uma encarregada dos serviços das escolas preliminares e complementares; a outra a serviço das Escolas Normais, ginásios e cursos superiores; e a terceira instituída para o Conselho Superior composto por membros do ensino particular e de inspetores distritais nomeados pelo presidente do estado. (idem, ibidem). Esse Conselho, mostrando ineficiência na fiscalização do ensino público, foi extinto em 1897 e trocado pela Inspetoria Geral do Ensino Público.

De acordo com Saviani (2005), a reforma da Instrução Pública de 1892 previa a adequada formação das peças fundamentais na boa execução dos preceitos reformadores e modernizadores do ensino público, os professores. O autor afirma que o sistema escolar paulista foi construído com foco na formação de seus professores e na renovação da metodologia de ensino, tendo como pedra de toque, para a integral reorganização da Instrução Pública, a implantação da Escola-Modelo.

\footnotetext{
4 Também foram criadas as demais secretarias: da Justiça, da Agricultura, Comércio e Obras Públicas e da Fazenda do Estado de São Paulo, sendo delegadas suas respectivas atribuições.
} 
O ensino paulista primário foi, então, dividido em elementar e complementar. O elementar, com duração de quatro anos, seria ministrado por professores normalistas. Já o complementar dava continuidade aos estudos preliminares, um curso intermediário entre o primário e o Normal. As escolas que possuíssem mais de trinta alunos contariam com um professor titular para cada série, além do professor adjunto que o substituiria em caso de ausência.

Portanto, os anos 90 do século XIX principiam a implantação das escolas primárias graduadas e em Grupos Escolares em oposição às escolas isoladas, características do período monárquico. ${ }^{5}$ Essa fase, denominada As escolas graduadas $e$ o ideário do Iluminismo republicano (1890-1931), ${ }^{6}$ passa a representar um novo modelo de organização do ensino primário brasileiro, visto que os grupos em muito se diferenciavam (ou deveriam se diferenciar) das escolas isoladas.

\section{Alunos, eleitores e militantes em fornadas republicanas}

No final do século XIX, São Paulo, pioneiro na criação de um sistema de ensino unificado, teve seu desenvolvimento acelerado por uma demanda populacional motivada, dentre outros fatores, pela abolição da escravatura em 1888, o que fez aumentar a entrada de imigrantes europeus para suprir a necessidade brasileira de mãode-obra. ${ }^{7}$

\footnotetext{
${ }^{5}$ As iniciativas republicanas de universalização do ensino criaram os Grupos Escolares para atender inicialmente os grandes centros urbanos e as escolas reunidas, os centros menores, ambos os tipos caracterizados pelo agrupamento de escolas elementares. (CARDOSO, 2013). Porém, neste trabalho, serão considerados apenas os grupos.

${ }^{6}$ A segunda fase tem começo em 1931, passa pelas leis orgânicas do ensino da reforma Capanema e se completa com a primeira Lei de Diretrizes e Bases da Educação Nacional (LDB n.4.024/61) em 1961. A partir de então, a terceira fase começa e se finaliza com a aprovação da nova LDB (lei n.9.394/96) em 1996, representando, portanto, a unificação da educação nacional que abrange a rede pública e privada influenciada pela concepção produtivista da escola.

${ }^{7} \mathrm{O}$ destino principal desses imigrantes era o estado de São Paulo, que recebeu, em 1890, 70\% dos estrangeiros que entraram no país. (SCHWARCZ, 2012).
} 
Nesse ponto, o governo brasileiro favoreceu a vinda de imigrantes com a propaganda da terra da promissão (convertida em uma espécie de escravidão por dívida), o que não passava de uma substituição do cativeiro africano, naquele momento, em vias de se extinguir. (SCHWARCZ, 2012).

A massa de imigrantes, convicta de que as promessas republicanas não foram nem seriam concretizadas, transformou seus sonhos em revoltas, as quais, paralelas a um quadro de violência urbana já instituído, contribuiu para que a responsabilidade fosse atribuída tanto à própria população estrangeira, quanto à liberdade dos negros. Com base nas teorias do darwinismo social, concebia-se que a miscigenação cultural era a principal responsável pela desordem e pelo desequilíbrio apontados na época. Nesse contexto, a escola agrupada passa a ser um instrumento do Estado para a uniformização da língua.

Em contrapartida, algumas interpretações eram tecidas positivamente em favor dos imigrantes, uma vez que a imagem desses trabalhadores contribuía, diretamente, para a ideia do melhoramento social, seja pelo branqueamento da população, seja a partir da divulgação ampliada de um éthos de trabalho. (idem, p.36).

O destino inicial dessas pessoas era, principalmente, a lavoura cafeeira, no entanto, devido à crise agrícola, elas foram incorporadas ao funcionamento das cidades, que geravam empregos ligados ao artesanato e à indústria. Assim, a sociedade passava a contar com diversas habilidades profissionais trazidas pelos imigrantes, os quais formavam, então, a camada dos profissionais liberais.

Tamanho crescimento populacional e urbano apresentou barreiras à universalização da educação fundamental, pois as escolas abertas não conseguiam acompanhar esse aumento rápido e efetivo que a sociedade sofria. (MARCÍLIO, 2005). Porém, mediante a análise de ofícios e relatórios de diretores e inspetores dos Grupos 
Escolares no começo do século $\mathrm{XX}$, verificamos que talvez a válvula de condicionamento dessas barreiras não esteja apenas no crescimento demográfico, mas também na falta de investimento do Governo na Instrução Pública. É certo que o crescimento populacional criou o problema de infraestrutura, entretanto, como se verá mais adiante, algumas dificuldades desta natureza não tinham relação de causa e efeito com o aumento populacional.

Nesse sentido, são constantes as observações feitas pelos diretores com relação ao desequilíbrio da lei da oferta e da procura de vagas escolares: o número de alunos se limita devido à falta de infraestrutura básica, como salas de aula, material escolar, utensílios, objetos e até mesmo professores, para o regular funcionamento do grupo:

Grandes foram as difficuldades com que tivemos que luctar nos primeiros mezes, devido não só a morosidade no resto da mobilia e material escolar, como ainda mais, a falta de professores.

Tendo concorrido a matricula, no primeiro mez, perto de 500 alunos, e dispondo este grupo de 9 professores apenas, foi necessario que accumulasse em algumas classes do $1 .^{\circ}$ anno, mais de 60 alunnos, e assim se conservou até principios de abril. (Grupo Escolar Dr. Júlio de Mesquita - Itapira, 1901).

Mesmo as condições de oferta sendo precárias e a procura, alta - perto de 500 alunos, motivada pelo crescimento demográfico, as adaptações foram feitas e algumas classes do $1^{\circ}$ ano funcionaram com uma capacidade superior à adequada até o mês de abril. O diretor diz que, a partir de então, os problemas foram diminuindo com a nomeação de novos professores e que, à primeira vista, ele poderia ter sido visto como o culpado por matricular tantos alunos quando só havia nove professores em exercício, mas:

[...] attendendo ao mesmo tempo os justos e constantes pedidos dos interessados - paes, tutores e protectores de crianças -, foi que acceitei tão numerosa quantidade de alumnos.

Não podia mesmo proceder de outra forma, porquanto essa cidade que passara tantos annos sem nem uma escola, e que, com a installação do grupo deixavam de existir as que ha pouco tinhão sido providas, a população escolar affluiria, sem duvida, para o grupo, unico estabelecimento de instrucção existente nesta localidade. (Grupo Escolar Júlio de Mesquita - Itapira, 1901). 
Com a instalação do grupo, Itapira deixou de ter outras escolas, o que fez crescer a procura pelas vagas existentes, aumentando, assim, a concorrência. Como única instituição de ensino da cidade, a crítica do diretor recai sobre a inexistência de infraestrutura. Embora sejam os primeiros meses de vida, nesse período, o grupo não conseguiu atender à demanda de alunos por falta de professores e funcionou com elevado número de alunos em cada sala.

A situação de alguns grupos era precária, limitando até o número de matrículas feitas devido à falta de espaço nas salas, já que muitas delas não comportavam o número máximo de alunos:

[...] tendo concorrido numero de candidatos excedente ás vagas verificadas nos diversos annos de ambas as secções, o que deu logar a ter de valer-me do recurso facultado pelo Regimento Interno, isto é, fui constrangido a fazer o sorteio das vagas existentes, mais porque a capacidade de diversas salas onde funcionam annos inferiores não comporta o maximo e, este inconveniente, subsistirá ainda si a futura matricula tiver de verificar-se nas mesmas condições, isto é, tornandose como critério apenas a capacidade cada sala de aula. (Grupo Escolar Cel. Flaminio Ferreira - Limeira, 1906).

O interesse pelo número limitado de crianças atendidas talvez possa se justificar pelas apostas feitas na alfabetização por parte do novo governo republicano, tendo em vista que saber ler e escrever passou a ser condição para que todo cidadão brasileiro, em pleno gozo de seus direitos civis e políticos, pudesse ser qualificado como eleitor.

De acordo com Carvalho (1987), as inovações republicanas referentes à franquia eleitoral resumiram-se em eliminar a exigência de renda, mantendo a de alfabetização. Dessa forma, havia um eleitorado potencial, mas não real, o que não eliminava possíveis deturpações eleitorais.

A quantidade de analfabetos que o país comportava representava um atraso ao progresso nacional almejado pelo novo governo, em virtude de a Constituição Republicana considerar a alfabetização como condição para participar das eleições 
públicas. Se a reforma eleitoral de 1881 reduziu os votantes para cerca de $1 \%$ de toda a população, a Constituição de 1891 subiu esse número para 2\% (MATTOS, 2012), sendo ainda, porém, insuficiente para modificar o quadro educacional brasileiro.

\section{Filosofia das escolas graduadas: a ordenação da ordem}

O contexto social caracterizado pelo fim do trabalho escravo e pela implantação de um novo governo no país apontava não só a necessidade de substituir a mão-de-obra anterior e de se conservar as hierarquias sociais já solidamente estabelecidas, mas também a fixação de critérios diferenciados de cidadania. A questão racial, que fomentou diferenças sociais, apresentava-se como justificativa viável para sustentar o jogo de interesses que se construía. (SCHWARCZ, 1993).

Intelectuais da época tentavam, por assim dizer, adaptar a ciência positiva e determinista a um Brasil miscigenado no intuito de ditar os destinos do país. Vinculados a instituições educacionais, principalmente, os museus etnográficos, esses cientistas difundiam uma cultura evolutiva pautada na classificação e hierarquização dos elementos humanos para, então, chegar à ciência e ordem ausente nesse tipo de produção intelectual. (idem, ibidem).

Manter a ordem social e reprimir qualquer dado que a desestabilizasse se torna objetivo do novo governo republicano. Dessa forma, sendo a alfabetização critério para a obtenção da cidadania, a estratégia do governo não poderia ser diferente: modelar os cidadãos da forma almejada, com ordem e disciplina.

Tal intuito só poderia ser concretizado na primária formação do homem, sendo implementadas, assim, as escolas graduadas como um braço do esqueleto republicano, as quais, por meio da seriação do ensino, formatariam os alunos da forma desejada. 
Essa proposta se contrapunha à herança imperial que havia deixado uma escola configurada como a extensão da casa do professor e muitas delas funcionavam em paróquias, cômodos de comércio, salas cujo aluguel ficava por conta do mestre escola. (BUFFA, 2002). Esse mestre não possuía formação específica para o magistério, mas transmitia conhecimentos de leitura, escrita, cálculo e doutrina cristã pelo método tradicional baseado na memorização e repetição e por meio do ensino individualizado.

O método individual atendia às necessidades de cada aluno em uníssono, pois todos eles eram reunidos em uma única sala, independentemente, da idade e do adiantamento escolar. Dessa forma, não só a escola poderia ser vista como a extensão da casa do professor, como o próprio professor poderia ser encarado como o pai de família que cuidava e instruía seus filhos.

A aparente diferença entre as escolas graduadas e as isoladas se deve ao fato de os Grupos Escolares funcionarem à semelhança da Escola-Modelo que estabelecia a seriação do ensino, padrão estruturado sob uma concepção racionalista que pressupunha a divisão dos alunos em classes agrupadas pelo nível de conhecimento, contando com um professor para cada série e um diretor para cada escola. Até então, o conhecimento não previa idade ideal de aprendizagem nem uniformidade entre os vários saberes escolares.

\subsection{O ensino em série: classificação e formatação}

Com a inserção das escolas graduadas, o ensino passou a levar em conta a idade do aluno, estabelecendo vínculos entre ano escolar e ano civil, nível de aprendizagem e estágio de conhecimento das várias disciplinas entre si. A passagem de uma série para outra era feita por meio do exame, o qual media o sucesso ou o fracasso do aluno. 
Assim, dois métodos passaram a ser usados, a organização dos alunos na classe, método simultâneo, e a organização dos saberes, método intuitivo. (VIDAL, 2005).

Mediante essa nova estrutura e concepção de escola concretizada na implantação dos Grupos Escolares, a disposição espacial dos alunos em duas seções, uma masculina e outra feminina, e cada uma subdividida em séries, denota a tentativa de instauração da ordem por meio, inicialmente, da classificação da criança que ali ingressasse e, em segundo lugar, pela distribuição e formatação geral do grupo como um todo.

Apesar de as escolas graduadas representarem para os poderes públicos modelo ideal de instrução preliminar a ser imposta a toda a população, mas a sua implantação nunca ter substituído totalmente as escolas isoladas, a construção simbólica de exaltação dos grupos deve ser, cuidadosamente, analisada a fim de não criar interpretações sem as devidas críticas.

A atmosfera republicana de modernização educacional propiciava construções de sentido tecidas frente à carência generalizada das escolas monárquicas, mas também pela deficiência dos Grupos Escolares que surge ao ser desmistificada toda a simbologia republicana.

Quanto à graduação do ensino, os relatórios e ofícios do início do século XX de Grupos Escolares paulistas evidenciam desvios com relação ao estrito seguimento desses preceitos, pois, em sua maioria, os grupos juntavam alunos de níveis de conhecimento diferentes, seja por falta de salas de aula para cada ano ou por falta de professores.

Motivados pelo período inicial de adaptação de um novo governo, problemas de base organizacional como esses revelam o desinteresse do governo pela Instrução Pública, não obstante a propaganda a seu favor, tirando proveito disso para formar 
eleitores, ao mesmo tempo em que dava visibilidade à administração republicana por meio da abertura de escolas.

Exemplo disso é o Grupo Escolar Dr. Moraes Barros, de Piracicaba, cujos $3^{\circ}$ e $4^{\circ}$ anos da seção masculina funcionaram juntos, no ano de 1901 , assim como os $4^{\circ}$ e $5^{\circ}$ anos da seção feminina, devido à falta de salas de aula. O diretor, no relatório encaminhado à Inspetoria, pede uma casa próxima para dar uma sala para cada ano e, assim, poder separar os gêneros:

Vou encerrar esta exposição, permitti-me, porém, que no momento disto acontecer, vos leve ao conhecimento do que, para o bom funcionamento desta casa de ensino e melhor aproveitamento por parte de seus alumnos no anno vindouro eu acho de necessidade fazer. Trata-se da separação dos $3^{\circ}, 4^{\circ}$ e $5^{\circ}$ annos masculinos, que agglomeradamente funciona em uma só sala, assim como os $4^{\circ}$ e $5^{\circ}$ annos femininos em outra.

Esta separação é fatal; para ella, porém, é preciso fazer acquisição de mais três salas e isto em outro prédio que não o do grupo, pois que este não as tem. Existe no entretanto uma casa muito proxima, que pode perfeitamente satisfazer esta necessidade. É espaçosa e tem portanto as acomodações precisas. Com a adaptação della, que a municipalidade daqui não se oppõe em fazer, pretendo agir de modo tal, que os $3^{\circ}, 4^{\circ}$ e $5^{\circ}$ anos masculinos nella funcionem, ficando no prédio primitivo toda a seção feminina e os $1^{\circ}$ e $1^{\circ}$ anos masculinos. É uma medida que não deixa de ser boa para a disciplina do estabelecimento. (Grupo Escolar Dr. Moraes Barros - Piracicaba, 1901).

Sem um prédio próprio para a instalação e funcionamento do grupo, juntavam-se diferentes séries em uma única sala na seção masculina e duas na seção feminina, organização que não seguia os padrões das Escolas-Modelo que previa a separação em série e gênero:

Encontrei o ensino mal dessiminado, quanto a sua classificação em annos, e execução; haviam dois primeiros annos e em ambas encontravam-se alunos de classes adiantada e atrazada indistinctamente, difficultando aos professores a execução do programma escholar. (Grupo Escolar de São José dos Campos, 1906).

Nesse caso, ao tomar posse do cargo, o diretor relata ter encontrado duas classes agrupadas de forma heterogênea no que tange à falta de classificação dos alunos por nível. A dúvida acerca da verdadeira intenção governamental na abertura dos Grupos 
Escolares permanece aberta e incorpora um novo condicionante. Se a preocupação era instruir a população, mesmo que em fase de adaptação, o Estado proveria os grupos de insfraestrutura básica com um prédio que comportasse, pelo menos, cada ano em uma sala.

Quanto ao segundo exemplo apresentado, a divisão dos alunos por nível não era tarefa do governo, cabia ao diretor classificá-los. Independentemente das razões que o levaram a isso, o antecessor do diretor em questão não cumpriu com sua responsabilidade adequadamente, mostrando que talvez a falha não seja apenas do governo, mas também de seus encarregados na fiscalização do ensino.

Com relação ao método intuitivo, ${ }^{8}$ introduzido para substituir a aprendizagem centrada na memorização e repetição de conteúdos, os propositores europeus e americanos o entendem como uma ferramenta pedagógica capaz de reverter a ineficiência do ensino que formava alunos com baixa competência de leitura, escrita e noções de cálculo.

Assim, tal método trabalharia com a observação que educa e aperfeiçoa os sentidos preparando na criança a base sobre a qual se constrói o conhecimento humano: perceber, analisar, abstrair, comparar, generalizar, sintetizar. (VALDEMARIN, 2004: 106).

Esse método apostava na valorização da intuição para apreensão dos conteúdos por meio da observação e dos sentidos de todo e qualquer conhecimento. (SOUZA, 2005). Também pressupunha o uso de salas e objetos adequados para esse modelo, além de uma biblioteca escolar detentora de modernos manuais de ensino.

O ensino intuitivo já aparece como pedra angular da renovação dos métodos da escola elementar no decreto n. 27 de 1890, que instituía a referida reforma da Escola Normal, no qual encontramos o programa de ensino das Escolas-Modelo adicionando o

\footnotetext{
${ }^{8} \mathrm{O}$ método intuitivo veio da Alemanha do final do século XVII e foi difundido, principalmente, por Pestalozzi e Fröebel. (SOUZA, 2005)
} 
estudo das lições de coisas com observação espontânea no primeiro e segundo grau. Na continuação, encontramos o seguinte artigo 23: As lições de coisas deverão ser mais empiricas do que theoricas, e o professor se esforçará por transmittir a seus discipulos noções claras e exactas, provocando o desenvolvimento gradual de suas faculdades.

As lições de coisas foram, no início do século, tão propagandeadas que a personagem Carlos, de Menino de Engenho, aplica o termo ao ensino de porcarias que lhe fazia o empregado Zé Guedes, encarregado de levar e trazê-lo da escola:

Eram assim as minhas lições de porcaria com aquele mestre que não se contentava com o lado teórico de seu magistério e também dava as suas lições de coisas. (REGO, 2012: 56) ${ }^{9}$

Referências semelhantes são feitas no Regimento Interno das Escolas Públicas, aprovado em 1894, sob o qual os Grupos Escolares funcionaram até em 1904, quando foi aprovado um regimento próprio, que dispõe que:

As licções sobre as matérias de qualquer dos annos do corso deverão, de accôrdo com o programma adoptado, ser mais praticas e concretas do que theoricas e abstractas, e encaminhadas de modo que as faculdades das crianças incitadas sejam a um desenvolvimento gradual e harmonico.

O professor também deveria ter em vista desenvolver a faculdade de observação e, para isso, empregue os processos intuitivos. Entretanto, grande parte dos relatórios dos Grupos Escolares apresenta uma situação que, segundo os diretores, atrapalhava o desenvolvimento do método de ensino. Impedimento que se mostra pautado, essencialmente, no aspecto edilício e no material escolar, entendido, no contexto, como a mobília:

Continuando a funcionar este Grupo, num predio sem as condições pedagogicas precisas, não deixam esse facto de acarretar prejuisos ao nosso fim, o de instruir de um modo pratico e intuitivo, porquanto esta deficiencia tem acarretado uma outra, muito sensível - a falta de material moderno.

Entretanto todas essas deficiências materiaes em breve vão desaparecer, com a construção do novo predio [...] (Grupo Escolar Dr. Jorge Tibiriçá - Bragança, 1906).

\footnotetext{
${ }^{9}$ Menino de Engenho, de autoria de José Lins do Rego, foi publicado em 1932.
} 
A deficiência existia e esse tipo de reclamação é, recorrentemente, encontrada nos relatórios dos diretores, os quais sempre ressaltam a falta de algum material escolar

que atrapalha o seguimento do programa de ensino instituído. É necessário esclarecer o termo material escolar, cujo significado deve ser entendido pelo contexto apresentado nos documentos, os quais estabelecem referência, essencialmente, com a mobília do grupo, ao passo que material didático se refere a livros, cadernos, canetas, giz etc.

É arriscado apontar de onde a defasagem se origina sem considerar o período de adaptação e instabilidade pelo qual a Primeira República passou. Porém, ainda no decreto n. 27 de 1890, a legislação afirma ser de responsabilidade do próprio governo promover o desenvolvimento da instrução.

De qualquer forma, as necessidades apontadas pelos diretores, por serem mais de ordem física do que conteudística, sugerem que os verdadeiros interesses estavam voltados para a aparência (e quiçá para o melhor manejo e desvio dos recursos financeiros) e não para a real essência da escola.

\subsection{Ordem militarizada: o grupo como batalhão escolar}

Criados na Primeira República, os Grupos Escolares eram vistos como a concretização da modernidade trazida pelo novo governo e tinham como função a formação do cidadão republicano. Dentro dessa visão, Valdemarin (2004) afirma que a escola tinha função essencial para a difusão de valores políticos, já que o Estado precisava de cidadãos que soubessem ler, escrever, compreender, pensar, condições que permitiriam a percepção das virtudes da organização social alcançada no momento. 
É exatamente essa a visão perpetuada pelos diretores dos grupos nos relatórios consultados, os quais evidenciam um discurso sempre relacionado à formação de um novo homem, o verdadeiro cidadão republicano:

A missão da escola dirige-se ao duplo fim de preparar o homem e o cidadão illuminando-o para a practica da vida no seio da sociedade civil. ( $2^{\circ}$ Grupo Escolar de Campinas, 1906).

Os Grupos Escolares tentavam incentivar a civilidade e os meios de adquirir ordem e disciplina por meio do desenvolvimento físico e moral baseado no ensino de ginástica para a seção feminina e exercícios militares para a masculina. Na foto abaixo, a ordenação das alunas evidencia o cumprimento disciplinar exigido pela escola:

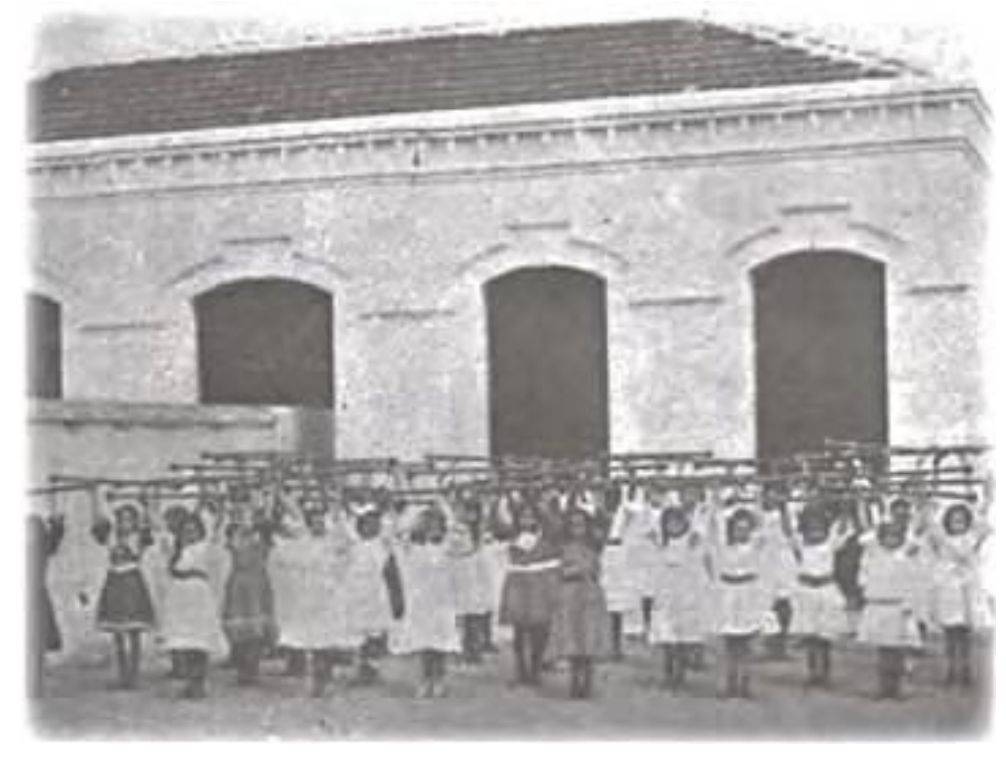

Segundo Grupo Escolar de Campinas

A imagem mostra que as meninas eram, sim, submetidas a exercícios físicos, porém saltam aos olhos a postura homogênea e rígida: pernas unidas, coluna ereta, braços alinhados e direcionados para cima segurando um bastão, sem grandes movimentos. O muro à esquerda, provavelmente, separa o ambiente reservado às meninas daquele atribuído aos meninos. 
Além de marcar a restrição de movimentos corporais do gênero feminino, a disposição dos bastões acima das cabeças das meninas resgata o desenho das cornijas, quase a refleti-las. Ambos, bastões e cornijas são encerrados pela cimalha, o ornamento mais alto da arquitetura do grupo onde se assenta o beiral do telhado, como a limitar o espaço de ação das meninas. Nesse sentido, o ornamento arquitetônico e a disposição dos bastões pelas meninas captados na fotografia sugerem a correlação entre hierarquia/ordem e limitação dos movimentos femininos.

Se, como dito inicialmente, por meio da classificação, formatação e distribuição dos elementos do grupo como um todo, a ordem seria instituída, as atividades corporais também contribuiriam para esse processo.

Dessa forma, a dominação simbólica era exercida pelos grupos por meio da prática de exercícios corporais, os quais submetiam o aluno-cidadão, de forma inconsciente, à incorporação de hábitos de ordem e civilidade, já que a escola permite, ao ultrapassar a dimensão cognitiva, o acesso a relações que envolvem outras extensões do ser humano. (BOURDIEU, 1996; 1999).

A designação de exercícios diferentes para meninas e meninos é uma das estratégias de inserção dos alunos na ordem das coisas, conjugando esquemas de pensamento e ação. No âmbito escolar, essa distribuição de exercícios físicos por gênero cede maior mobilidade e dominação em espaços externos aos meninos, cuja prática militar (batalhão escolar), muitas vezes, era feita em desfiles pela cidade; ao passo que as meninas se restringiam ao ambiente interno da escola. (idem, 1999).

Assim, o imaginário infantil sendo sustentado pelas analogias entre ensino militar e físico com conduta ordeira, nas palavras de Carvalho (1990), o significante não se isolava do significado (p.92), ou seja, a criança se apropriaria da ideia republicana de que a ordem traz o progresso, daí o incentivo à frequência às aulas: 
Não sem grande difficuldade consegui organizar definitivamente, não só para estimular os alumnos à frequencia como para attender a uma disposição (art 46) do citado Regimento Interno, uma campanha para o ensino de exercícios militares, achando-se lá os meninos bastante disciplinados e aptos para algumas evoluções.

Esse batalhão em mininatura, ainda fragmentado - tenho observado ha despertado a attenção das creanças, que se têm tornado mais assiduas às aulas, applicando-se melhor em umas lições, aguçadas pelo desejo de promoções. (Grupo Escolar de São Luiz de Paraitinga, 1906).

O trecho citado mostra que os exercícios militares eram desenvolvidos pela criação de um batalhão escolar, o qual era organizado como forma de manter a ordem e disciplina física e moral dos alunos dos grupos. Esse desejo era reforçado, constantemente, para estimular e atingir o progresso da nação:

Como disse acima os exercicios militares nas escolas publicas são de múltiplas vantagem, pois, além de constitutir meios de estímulos aos estudos e disciplina, ainda preparam os homens de amanhã para as necessidades que possa ter o Governo brazileiro.

Como sabeis, a paz é a base para o progresso de um povo, por isso nós brazileiros a adoramos, mas será esse o pensamento de todos os povos que nos rodeiam? Não será melhor trabalharmos para o progresso das nossa querida Patria, sem descurarmos dos meios de suas defeza? (Grupo Escolar da Liberdade - São Paulo, 1906).

A formação do batalhão escolar era levada a sério, muitos grupos recebiam ofertas de instruções de militares da cidade, já outros eram dirigidos pelos próprios professores da escola. No primeiro caso, o batalhão do $3^{\circ}$ Grupo Escolar do Brás possuía, como instrutor, inicialmente, um professor e, depois, um militar:

As primeiras instruções aos alumnos foram ministradas pelo professor do $3^{\circ}$ anno Pedro Ferrero Bicudo, que as desenvolveu bastante. Depois, em Maio, offereceu-se delicadamente para instruir o pequeno batalhão, o official reformado do corpo de bombeiros major Manoel Alexandre de Silus Junior, offerecimento que o Grupo acceitou com prazer. ( $3^{\circ}$ Grupo Escolar do Brás - São Paulo, 1906).

Assim, os relatórios denotam os esforços dos diretores quanto ao cumprimento das tentativas de instauração de um regime disciplinar nos grupos, paralelo ao desejo de progresso que o novo governo aplicava na criação e difusão das escolas primárias públicas. O próprio sentido da palavra batalhão denota a necessidade de uma enorme 
batalha contra o analfabetismo visível na época, o qual apenas com muita luta, preparo e disciplina - a encontrada no ensino militar - seriam capazes de vencer esse inimigo.

Para isso, o Grupo Escolar, como uma instituição que reunia escolas e pessoas de diversas origens, juntamente com a instauração da ordem e da disciplina, no ideário republicano, faria com que essas crianças desenvolvessem uma união que refletisse a formação de um grupo, a formação de uma classe. As imagens abaixo evidenciam exatamente essa tentativa disciplinar e homogeneizadora na ordenação das crianças uma ao lado da outra, em fileiras, para tirar a foto:

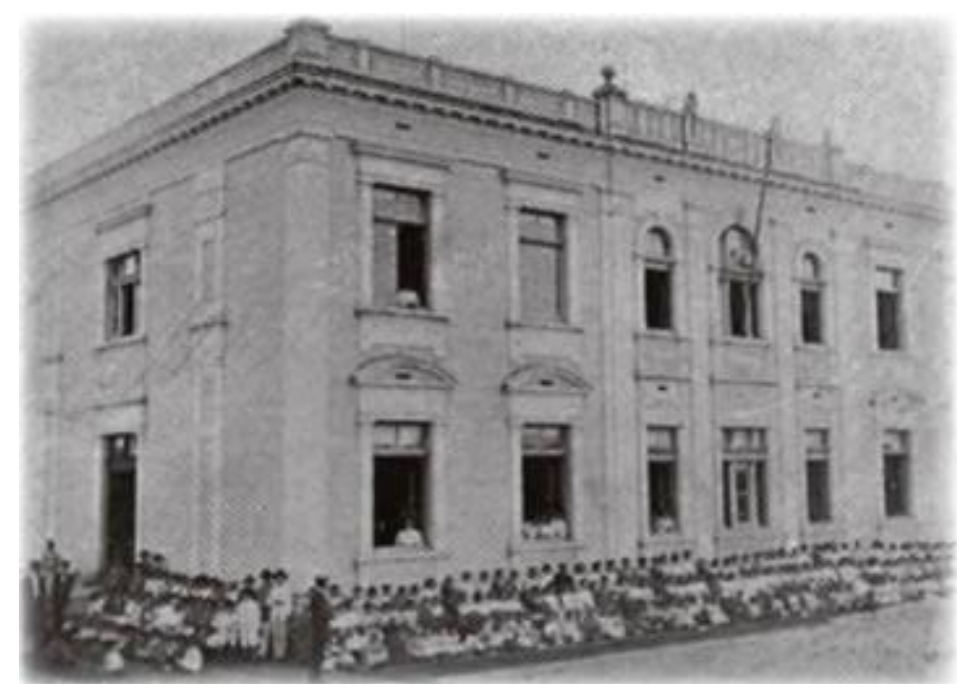

Grupo Escolar de Avaré 


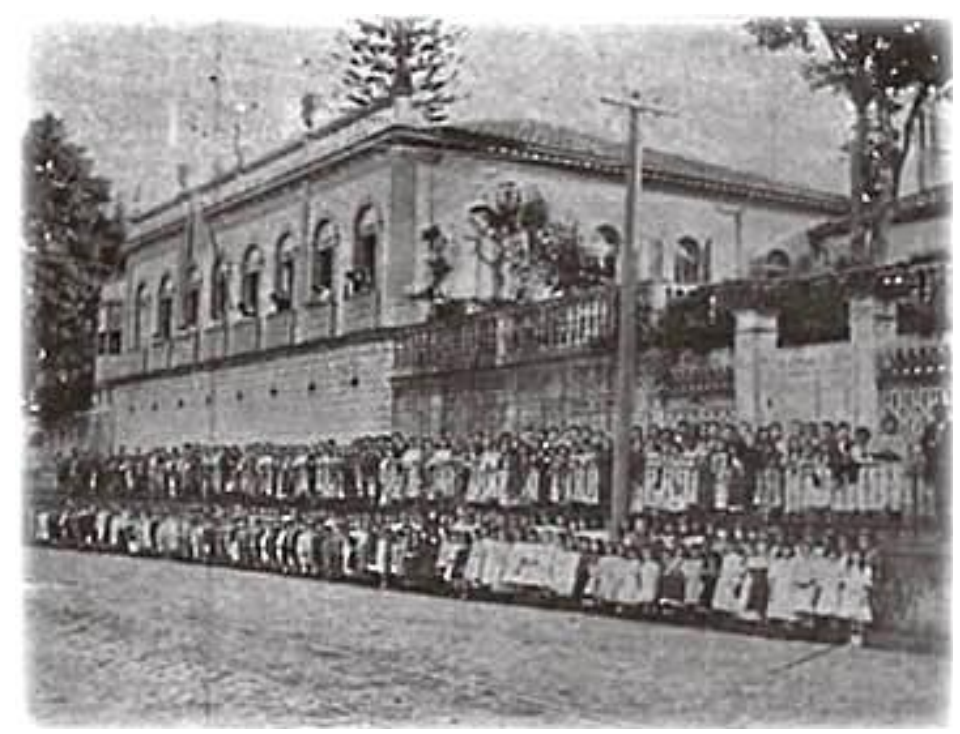

Grupo Escolar da Liberdade - São Paulo

Além disso, percebe-se que, em ambos os casos, os alunos estão dispostos em fileiras ao longo do prédio, o que reflete a própria estrutura arquitetônica dos grupos. As crianças de Avaré estão organizadas em duas fileiras, fazendo referência aos dois andares do grupo e acompanham tanto a parte da frente, como a lateral. Já no Grupo Escolar da Liberdade, a distribuição dos alunos espelha a disposição do prédio em terreno alto. Dessa forma, a organização dos alunos nas fotografias serve como recurso simbólico para marcar o pertencimento, ou seja, a identidade entre o alunado e o espaço escolar.

Outro vestígio interessante da identidade entre a figura e o espaço está na presença de alunos debruçados nos beirais das janelas, como se assistissem à formatura de alunos que já passaram por aquele ambiente. Esse arranjo sugere ainda a saída de fornadas, de forma(ta)ção em massa de cidadãos que a escola está apta a produzir.

Ao atingir o imaginário infantil, como essas crianças eram originárias de formações anteriores diferentes, a escola servia como um local de homogeneização, da 
qual sairiam cidadãos - militantes e militarizados - que representariam a ordem republicana em oposição ao regime anterior. (CARVALHO, 1990).

\section{Visibilidade instaurada: a ordem em construção}

A formação da escola graduada, com a implantação dos Grupos Escolares, trouxe a necessidade de uma nova organização do espaço escolar, de se adotar um espaço próprio para o ensino que portasse uma maior quantidade de salas, já que as séries passaram a funcionar separadamente, além de, teoricamente, ter que possuir locais apropriados para o exercício físico e galpões destinados ao abrigo dos alunos no período dos recreios. (BUFFA, 2002).

Recorrentemente, encontra-se na literatura os referidos edifícios escolares como grandes estruturas físicas erguidas para atender as necessidades e objetivos do novo modelo pedagógico instituído: amplas salas de aulas, ginásio, anfiteatro, laboratório, pátios para recreação, gabinete do diretor, sala dos professores, sala para arquivo e portaria.

Na primeira década do século XX, o Estado de São Paulo ganhou Grupos Escolares projetados por renomados arquitetos, somando um total de 101 no intervalo de 1894 a 1910. Para preencher o espaço dessas grandes construções, foram escolhidas mobílias escolares advindas de um moderno desenvolvimento de outros países, o que estimulou também, em São Paulo, o nascimento de um novo setor de produção industrial que comercializava móveis escolares com o restante do país. (idem)

No entanto, apenas alguns Grupos Escolares da primeira geração tiveram construções especiais como as relatadas, a maioria foi instalada em prédios adaptados - 
cedidos pela Câmara Municipal ou por personalidades locais - os quais, muitas vezes, apresentavam sérios problemas de ordem física.

\subsection{Material escolar: edifício e mobiliário}

Se grandes eram os problemas encontrados fora do contexto escolar, menores não seriam os internos. A literatura mostra que investiam na implementação de um ensino público moderno, no entanto, os apontamentos feitos pelos relatórios são amparados por argumentos pautados na falta de verba recebida e na ideia de que os auxílios governamentais não eram suficientes para suprir necessidades básicas do grupo:

Os moveis e utensilios desse Grupo Escolar necessitam de concertos, que ainda não foram feitos esse anno, com a verba do expediente, por terem sido pagas diversas contas que ficaram do anno proximo findo. Essa verba foi de $40 \$ 000$, e não dá para compras de mappas geographicos e para o fornecimento de cadernos para todos os alumnos do estabelecimento como anteriormente era feito. (Grupo Escolar Cel. Augusto César - Leme, 1906).

O relatório não discrimina onde foram utilizados esses $40 \$ 000$, nem as contas pagas do anno proximo findo, às quais o diretor se refere, fato que comprovaria a real necessidade de uma verba extra. Isso nos permite inferir que talvez o dinheiro recebido do governo não tenha sido aplicado no fim ao qual se destinava. Para cobrir a aparente escassez de recursos governamentais, recorria-se à Câmara Municipal:

Ao inspetor escolar que aqui viera, em visita, mostrei-lhe o estado em que achavam-se o telhado referido, e a seu conselho officiei à Municipalidade pedindo sérias providencias e fazendo vêr o perigo a que se achavam os professores e as meninas que frequentavam as nossas aulas.

Novamente a edilidade fez examinar a casa e não tardou em tomar outra, e offerecer os meios para que essa seção fosse transferida para ahi, até a sua reconstrução.

O predio está sendo demolido pela Camara e seria de muita conveniencia para o ensino, que fosse construido um edificio proprio para ambas as seções, e não como tem sido até agora, que difficulta tudo e até pode prejudicar o bom andamento do Grupo. (Grupo Escolar Augusto César - Leme, 1906). 
Dessa forma, fica evidente a ajuda da Câmara Municipal, mas aqui é necessário pensar em um estabelecimento de competências das partes que provinham a Instrução Pública. Na legislação estadual vigente na época - já que, como dito anteriormente, o Governo Federal delegou a frente da Educação aos estados -, encontramos, desde a criação dos Grupos Escolares (1893), uma fase de adaptação à República, às novas ordens sociais, políticas e econômicas que tentavam se instituir, de modo que os grupos funcionaram sob o regimento de 1894 das escolas públicas e, apenas 10 anos depois, sob um regimento interno próprio dos Grupos Escolares, cuja aprovação saiu decretada em 1904.

Em ambos os regimentos, os livros e demais objetos - o material didático destinados ao ensino preliminar são adotados e distribuídos pelo governo por meio dos inspetores de ensino. Já com relação aos prédios escolares, o Regulamento da Instrução de 1893 delega ao presidente do Estado a responsabilidade de prestar auxílio na construção de edifícios destinados às escolas preliminares, cujas municipalidades ajudassem pecuniariamente ou com terrenos e materiais. Assim, o Estado era o provedor principal, mas, de acordo com o documento, as Câmaras Municipais:

[...] interessadas no progresso da insctrucção nos respectivos municipios, têm o dever imprescindivel de velar pela execução da lei do ensino publico, prestando o seu auxilio ás auctoridades escolares e concorrendo por si para tornar uma realidade a instrucção popular. (art. 46 do decreto n. 218, de 27 de novembro de 1893).

Entretanto, não faltavam críticas às Câmaras Municipais pela ausência de interesse pela Instrução Pública, como encontrado no relatório do inspetor de ensino René de Oliveira Barreto:

Além disso, convém fazer que a camara se ponha em contacto directo com o ensino publico, a ver si por elle se interessa - causa que até agora não fez. A camara municipal de S. Paulo, a mais rica de todas, não mantém uma só escola primaria, não deu jamais um só auxilio ao governo, não deu um só passo em beneficio da instrucção publica. 
Em contrapartida, referências positivas são feitas por alguns diretores relatando a presença das Câmaras Municipais e da sociedade na participação do funcionamento escolar:

A Camara Municipal patenteou com seu concurso valioso a alta conta em que tem as questões do ensino, cujo desenvolvimento costuma amparar com solicitude, auxiliada por beneméritos cavalheiros desta localidade. (Grupo Escolar de Tatuí, 1906).

Com o trecho exposto, muito pertinente se torna a convicção de que talvez a intenção da Câmara Municipal não fosse exatamente a questão educacional, mas sim as vantagens que essa ajuda poderia trazer para o campo eleitoral dos beneméritos cavalheiros da localidade. Provavelmente, esse grupo de senhores locais encontraram uma estratégia de conversão política, a qual transformaria um auxílio prestado à instituição escolar em um possível número multiplicado de eleitores.

A provisão do ensino público, mesmo sendo estabelecido na legislação que o Estado é o responsável maior e que o Município também tem o dever de auxiliar, tangencia a questão política, uma vez que o controle do eleitorado era uma forma importante de definir, pelo menos, as tensões dentro das próprias cidades, nas quais se armavam além das disputas de interesses e faccionalismos, a concorrência pelo poder local. (CARVALHO, 1990).

Beneficiar a educação municipal seria propagandear figuras políticas e, provavelmente, os recursos financeiros estaduais direcionados ao material escolar (edilícia e mobília) eram reconduzidos aos cofres dos beneméritos cavalheiros.

A precariedade resultante desse jogo de interesses, atestada pelo conteúdo de muitos relatórios lidos, é inerente aos Grupos Escolares do começo do século XX, todos sempre apontando alguma necessidade material de que dependia, o funcionamento da escola:

[...] em nada abona o zelo dos que melhor deveriam velar para que o mobiliaria e material de ensino não apresentassem o estado desolador 
que ostentam e que tão mal impressionam ao espirito de um visitante ou curioso que percorra as dependencias do estabelecimento.

[...]

Salvo melhor resolução de V. Exc. é indispensavel e urgente uma reforma geral do mobiliario, maximé, no caso de remoção do mesmo para o novo prédio, onde, absolutamente não pode figurar decentemente.

[...] a dotação de material didactico que viesse completar, sufficientemente, a organisação do Grupo, de modo a facilitar, tanto quanto é possivel, o ensinamento pelo methodo adotado, approximando-o compativelmente com os recursos ao nosso alcance, do da Eschola Modelo, typo por onde se regulam os institutos de ensino que o Exmo. Governo vem disseminando pelo Estado. (Grupo Escolar Cel. Flaminio Ferreira - Limeira, 1906).

A referida distância existente entre o desempenho do grupo e a modernização do ensino primário não tem como ponto de vista os olhos dos alunos, mas sim os curiosos olhares de qualquer visitante que percorra as dependências do estabelecimento. As justificativas esclarecem a hipótese de que não era o melhoramento do ensino que estava em pauta, ornamentar o prédio daria o aspecto decente e a visibilidade que se alcançaria com uma verdadeira vitrine.

A ideia da escola como vitrine é capturada e salientada pela importância dada às questões edilícias em detrimento dos assuntos didáticos:

Simplesmente lamentaveis são as condições em que se acha o predio onde funciona o Grupo Escolar sob minha direcção, pois ha mais de sete annos que ele foi inaugurado e até hoje ainda não foi nem sujeito a uma pintura, nem si quer a uma limpeza geral, tão util quão necessaria.

Durante estes sete annos decorridos, creio, foi completamente esquecido o disposto $\mathrm{n}^{\circ}$ 5, art. 34, cap. IX, do Regimento Interno que diz respeito à Higiene Escolar.

[...]

Não é menos lamentavel o estado em que se acha o material escolar deste Grupo: carteiras bastante estragadas, muitas dellas inuteis; os armarios tanto os do gabinete do Director como os das diversas salas de aulas, não têm chaves, e poucos são os que conservam os vidros não quebrados; estão emfim, mal conservados.

[...]

Quanto ao material didactico é insufficiente o que ha. Isto, porém, requisitarei dentro da epocha legal. [...] Poucas são as obras que há na biblioteca; livros para fornecer aos alumnos estão todos em muito mau estado e, portanto, muitos delles inuteis. Giz, pennas, canetas, tinta, nada disso existe. (Grupo Escolar Dr. Augusto Reis - São Manoel do Paraíso, 1906). 
No mínimo, intrigante se faz a leitura do trecho acima, já que o diretor reclama a falta de pintura e limpeza geral, além da situação da mobília escolar, embasando suas queixas no seguimento das normas de higiene escolar presente no Regimento Interno dos Grupos Escolares.

Contudo, evidencia-se que a recomposição do material didático seria solicitada em época legal, diferentemente das outras necessidades do grupo apresentadas, como se houvesse períodos distintos para os pedidos de mobília, pintura e limpeza e para os de material didático, o que a legislação vigente não confirma.

Além do jogo de empurra-empurra entre Estado e Município, as preocupações com o aspecto visual da escola sugerem que o Estado, como o agente da própria Instrução Pública, estava longe de atuar na efetiva educação da população. Esse quadro incerto em que funcionavam alguns grupos mostra que o projeto de expansão das escolas públicas primárias, sem o adequado planejamento, obteve efeito contrário ao esperado e desejado.

No intuito de expandir a Instrução Pública primária com qualidade e, assim, aumentar a gama de eleitores, o Estado - e aqui incluímos todos os membros auxiliares na provisão do ensino, como já foi exposto - mostrou-se sem estrutura e preparo necessários, pelo menos, até meados da segunda década republicana.

São claras e constantes as reclamações dos diretores sobre melhorias nas condições físicas dos prédios para oferecer acomodações apropriadas, visando à criação de biblioteca, renovação/conserto da mobília escolar, pintura das paredes, substituição de vidros quebrados, construção de galpões para abrigo das crianças etc. Em poucos relatórios reclama-se de material didático para consulta de alunos e professores, o que não quer dizer que a dotação fosse suficiente, mas simplesmente que não era alvo de preocupação por parte da administração escolar: 
[...] é, pois, de vêr-se que todo o material está bastante danificado, necessitando, por isso, de concerto e limpeza geral e sem demora. $\mathrm{O}$ predio do grupo necessita de alguns reparos, taes como: vistoria geral no telhado, cimentação do porão, revestimento dos muros e pinturas. (Grupo Escolar Gabriel Prestes - Lorena, 1906).

É evidente que o grupo passava por dificuldades, mas devemos considerar, pelo trecho exposto, que as reclamações aparentam mais uma preocupação pessoal do diretor em apresentar para o público externo uma escola repaginada do que queixas que visassem o real melhoramento do ensino público.

Tal fato confirma que, entre a proposta republicana paulista de Instrução Pública e sua efetiva realização, havia um grande caminho ainda a ser percorrido, pois é possível constatar que a falta de preocupação não era apenas do governo, mas também dos membros da fiscalização do ensino a serviço dele.

Exemplo disso é, como exposto anteriormente, ser de responsabilidade do Estado financiar a construção de prédios próprios para os Grupos Escolares, mas até o período dos documentos analisados, a maioria deles não apresentava edifícios próprios e sim adaptados pela Municipalidade ou até mesmo por pessoas importantes da cidade.

No caso do Grupo Escolar de São José dos Campos, em relatório de 1906, o diretor expõe esse tipo de situação:

[...] adaptado pela Camara Municipal, apesar das grandes despesas que acarretou para o seu erário, não foi possivel deixal-o nas condições precisas para o fim a que se destina. [...] ha no entanto lacunas que subsistem pela impossibilidade absoluta de removel-as. [...] A começar pelas exhalações deleterias das cloacas, que se acham collocadas mui proximas destas, por defficiencia de terreno. Alem disto, não possue galpão, onde as creanças possam se abrigar dos rigores da canicula e das chuvas, sendo preciso para resguardal-as das intempéries, fazer recreio na classe, prejudicando a boa ordem escholar, obrigando a creança a faser o seu lunch na propria sala de aula [...] Algumas tem o inconveniente de servirem de passagem para todas as outras, onde se acham installadas as classes escholares. [...] Existem duas salas que são divididas por um tabique de madeira, o que força os professores a faserem as aulas mutuamente [...]

$[\ldots]$

O mobiliário é antigo e estragado. As carteiras são em sua maioria, systema paulista para duas creanças. Somente uma aula possue carteiras "Chandler", que apesar de velhas são as melhores [...] 


\section{$[\ldots]$}

É por demais, insufficiente, o material escholar - as professoras lutam com enorme difficuldade para se faserem comprehender em suas explicações diarias - pois, apenas dispoem de quadros negros, espheras geographicas, mappas muraes e alguns exemplares do "Museu Brasileiro", havendo urgente necessidade de aparelhos para o ensino de sciencias physicas e naturais, gymnastica e geometria.

O relato acima evidencia um quadro, diferentemente, precário das condições e normas previstas pela legislação vigente na época para os Grupos Escolares. No que se refere à ausência de galpões para abrigo das crianças durante o recreio, de salas divididas por um tabique de madeira, conjugando aulas de séries diferentes, de falta de material didático para o uso do método intuitivo, o padrão dos grupos, realmente, está distante do suposto modelo escolar idealizado pelos políticos republicanos do final do século XIX.

Que tais construções tenham sido idealizadas e, posteriormente ao período recortado para nossa análise, concretizadas, não cabe discutir com o mérito de concluir o que é possível de se fazer nesse momento. Diante da situação dos Grupos Escolares paulistas do final do século XIX e começo do século XX exposta pelos ofícios e relatórios consultados, infere-se que, independentemente do projeto educacional do início da República, as deficiências existiam, fossem elas causadas pela difusão escolar má executada ou pelas reais preocupações do governo em legitimar-se.

A visibilidade se consolidava na construção de prédios monumentais destinados aos Grupos Escolares: 


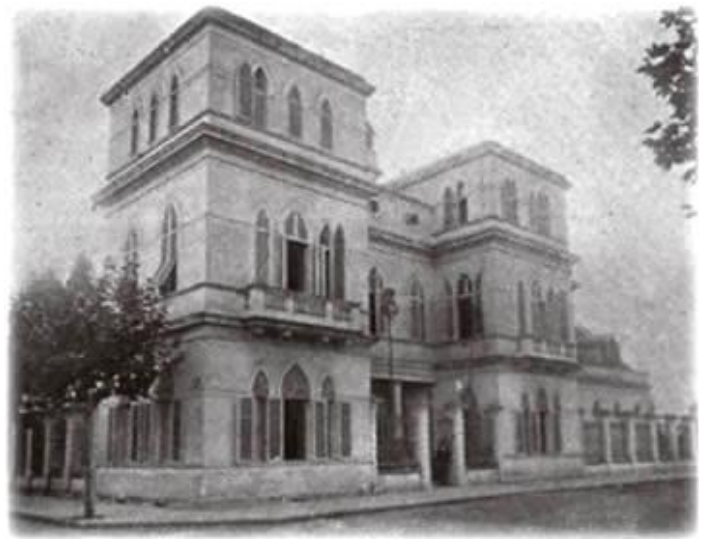

Grupo Escolar do Pari - São Paulo

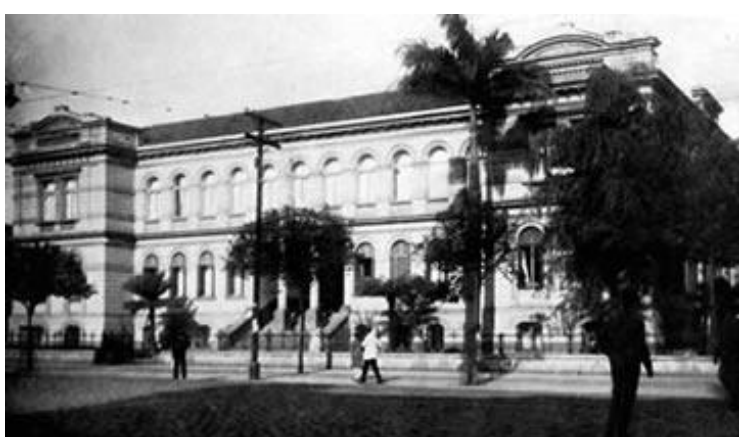

Segundo Grupo Escolar do Brás - São Paulo

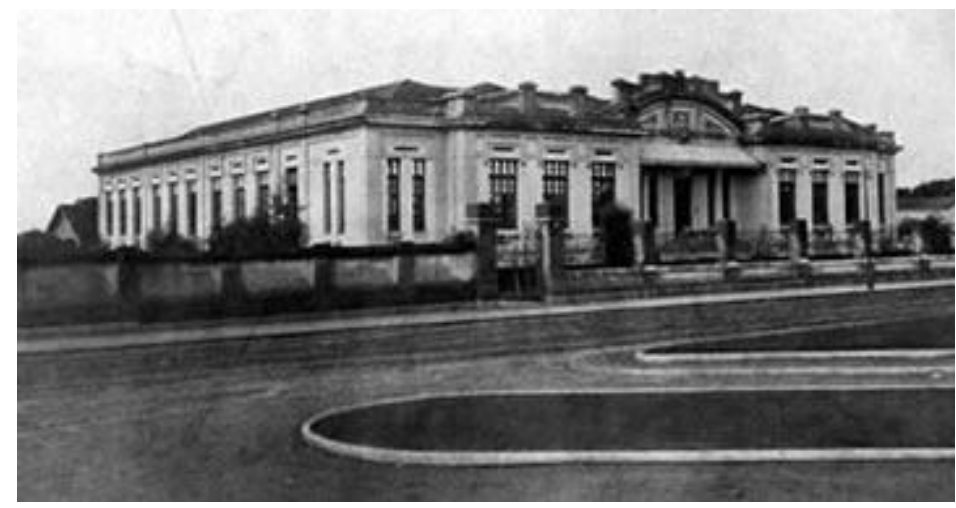

Grupo Escolar Tatuí

Essa visibilidade poderia assumir, de acordo com as imagens acima, três panoramas: um prédio de três andares estruturado em duas torres altas e robustas, como no Grupo Escolar do Pari; um grande edifício de dois andares, alongado e marcado pelo avanço das extremidades no Grupo do Brás; e o enorme edifício térreo, que se expande na horizontalidade, ganhando em amplidão e magnitude.

Juntamente a isso, a arborização que preenche o espaço frontal dos prédios harmoniza a paisagem ao se corresponder com a configuração arquitetônica dos grupos, pois no Brás as árvores seguem o condicionado olhar vertical instaurado e em Tatuí o jardim aplainado e sem plantação acompanha a amplitude horizontal alcançada pelo prédio escolar, deixando-o totalmente descoberto. 
Dessa forma, por apresentar uma estrutura sólida e imponente, a escola carrega consigo a ideia de monumento, com a qual nenhuma casa ou construção próxima é capaz de competir.

Portanto, contata-se que as autoridades republicanas se preocupavam em dotar o espaço escolar de identidade, como se a escola cumprisse uma função educativa na sociedade ao representar uma forma de condicionar o aluno a obter determinada formação política e social. As construções dos grupos representavam tanto a casa do saber como um conjunto de projetos políticos. (Faria Filho e Vidal apud MARCÍLIO, 2005).

\subsection{A pedagogia dos prêmios nos ajustes didáticos}

\subsubsection{A classe docente: trabalho nos bastidores}

Como atores do contexto escolar, os professores surgem, de acordo com Souza (2005), como membros de uma classe reconhecida e dignificada devido à atuação docente nos Grupos Escolares. Acrescenta que Não se pode subestimar a enorme relevância dos grupos escolares na profissionalização do magistério primário, especialmente na construção da identidade docente. (idem, p.117). Porém, os relatórios dos grupos do começo do século XX não confirmam o que diz a literatura, pois não apresentam os professores com toda essa força simbólica exposta pela autora.

Possivelmente, o alegado prestígio social dos professores é decorrente dos novos prédios adquiridos, posteriormente ao recorte temporal de nossa pesquisa, por essas escolas, os quais, localizados em perímetro urbano, ofereciam melhores condições de vida e de trabalho. 
Nesse sentido, o destaque alcançado pelo docente estava impresso não na profissão propriamente dita, mas na contraposição física - mesmo que inicialmente precária - dos Grupos Escolares e das demais escolas preliminares que existiam até então.

Dessa forma, a visibilidade referida pela autora talvez tenha que ser relativizada e, cuidadosamente, analisada, pois as referências à inabilidade e ao despreparo de alguns docentes são, frequentemente, encontradas nos documentos:

Durante o anno findo, foram por assim dizer centenas as ausências de professores por licença e por conseguinte, raro não foi o mez que não funcionasse pelo menos um substituto; essa instabilidade como é fácil de vêr-se, não deixou de acarretar embaraços na marcha intellectual do ensino neste estabelecimento. [...] um substituto não diplomado, inteiramente alheio aos methodos modernos de ensino, só com muito bôa vontade e boa direção, dará conta do seu mister. [...] $\mathrm{O}$ inconveniente está principalmente, no sacrifficio da classe onde o substituto antes de exercer o magistério sem proficiência, gastou pelo menos metade do período de substituição em ensaios, ao lado do director que o guia. (Grupo Escolar Dr. Jorge Tibiriçá - Bragança, 1906).

Os professores, nos primeiros anos, eram selecionados por meio de concursos públicos. Inicialmente, vinham de escolas isoladas e eram nomeados como adjuntos pelos diretores. Isso se deve ao fato de o Governo, mesmo tendo decretado que os professores dos Grupos Escolares seriam, em sua maioria, normalistas, ter de recorrer a professores formados antes da criação das Escolas-Modelo devido à falta de um quadro professoral qualificado. Por isso, muitos professores considerados despreparados talvez o fossem por falta de formação adequada e consequente desconhecimento da nova organização dos Grupos Escolares.

A escolha desses professores era feita, aleatoriamente, pelo governo que optava tanto por professores normalistas, como complementaristas. (SOUZA, 2005). Entretanto, além de acrescentarem os professores preliminares, os relatórios evidenciam que a escolha não era feita de forma aleatória, inclusive os ofícios trazem sugestões, 
pedidos e recomendações de determinados professores para preencherem as vagas existentes e para fazerem substituições temporárias:

Tendo me communicado, conforme documento junto, a professora D. Branca de Azevedo não poder acceitar o logar, neste Grupo Escolar, para o qual fora proposta, isto por não poder-se retirar de Piracicaba, onde reside, devido a grave estado de saúde de sua mãe - tenho a honra de pedir que vos digneis de nomear para $04^{\circ}$ anno deste estabelecimento, D. Carmela Lombardi e - em logar de D. Branca de Azevedo, como indiquei em meu officio de 17 do mez p. passado peço que seja nomeada a professora preliminar D. Lucia Pereira, interinamente, por não têr ela 18 anos de edade, como consta da publica forma de seu diploma que junto a este. (Grupo Escolar de Serra Negra, 1902).

Concessões governamentais autorizavam permutas entre professores de grupos

diferentes do estado de São Paulo:

Tendo o cidadão Quirino de Araújo, professor neste $2^{\circ}$ Grupo Escolar do Bras, requerido permuta com o professor da $1^{\text {a }}$ cadeira de Sant'anna, nesta capital, si essa permuta for concedida, proponho, de accordo com o art. 61 do Regulamento em vigor (11 de janeiro de 1898), que o logar de auxiliar, então vago, seja preenchido pelo cidadão Antonio Rodrigues do Espirito Santo, adjuncto deste mesmo estabelecimento, pois que reune em si todos os predicados de um antigo e exemplar funcionário. (Grupo Escolar do Brás - São Paulo, 1902).

Apesar da condição de aprovação da permuta, o diretor já havia enviado, juntamente com o pedido, a sugestão de um professor substituto para o lugar vago. Sobre as substituições, Souza aponta que os docentes substitutos, preferencialmente, os normalistas ou complementaristas, eram nomeados pelo secretário do Interior e da Justiça e deviam comparecer diariamente na escola, mas só recebiam quando, de fato, efetuavam a substituição.

De acordo com a citação do Grupo Escolar de Serra Negra, os professores substitutos não necessariamente haviam passado por uma Escola Normal ou Complementar, condição estabelecida pelo Regimento Interno dos Grupos Escolares para a contratação. No caso, a professora citada, D. Lucia Pereira, era uma professora preliminar e estava sendo proposta para uma vaga de substituta. 
Alguns desses professores, como dito anteriormente, eram transferidos de escolas isoladas, fato que os diretores não apoiavam, pois tais docentes não faziam uso dos modernos métodos de ensino:

[...] providos os logares vagos por professores que tiveram seu tirocinio em escolas isoladas, trazem elles, destas para o Grupo, os vicios adquiridos nellas, o que eles como todo viciado, pretendem fazer substituir neste.

D'ahi, o esforço titanico, de que precisa lançar mão o Director operoso, para amoldar o novo adjuncto às modernas exigências do ensino, de modo a transformal-o em um bom elemento para o estabelecimento; ideal que raramente se alcança, depois de uma grande lucta.

Neste caso, a incompatibilidade resultante, entre o professor viciado, recalcitrante, e o Director operoso, organisador, torna-se manifesto; e a consequência de uma tal anomalia ainda é a desorganisação do ensino, alem do estado moral que esse estado de cousas origina. (Grupo Escolar de São Simão, 1906).

Percebe-se que os professores das escolas isoladas eram transferidos para os Grupos Escolares, sem nenhum tipo de treinamento para que eles pudessem aprender os novos métodos e desenvolver satisfatoriamente seu trabalho.

Assim, muitos começaram a retomar o método repetitivo das cartilhas, utilizando-as ainda por algum tempo, seja por falta de conhecimento dos modernos materiais didáticos - ou pela falta deles nos grupos, como já evidenciado neste trabalho - seja por estarem presos aos métodos pelos quais foram alfabetizados.

Tais professores não passaram por Escolas Normais, que já inutilizavam as cartilhas:

Estou certo que attendereis ao pedido, pois do contrario haverá difficuldade no regular funccionamento deste grupo, devido a escassez de livros didacticos.

Convem scientificar-vos que este estabelecimento só teve uma dotação em 1902; de então para cá só foi accrescida com poucos exemplares do livro "Vida Infantil" e algumas cartilhas. (Grupo Escolar Dr. Cesário Motta - Itu, 1906).

Para ultrapassar essas barreiras, algumas medidas teriam sido tomadas com o intuito de preparar o professorado para o novo ensino proposto, tais como conferências de atualização do magistério. (SOUZA, 2005). 
Porém, nos relatórios e ofícios consultados, nenhuma referência a esse tipo de apoio ao professor foi encontrada, exceto um auxílio financeiro dado, pela Câmara Municipal de Ribeirão Preto, aos docentes normalistas do Grupo Escolar:

Nesta cidade de vida carissima, onde o professor estadoal tem os mesmos vencimentos que nas demais cidades do norte e sul do Estado, só um auxilio equivalente, compensará a sua permanencia aqui, como acontece com as Camaras de Cravinhos, São Simão e Sertãozinho que dão a cada professor normalista de 100 a $150 \$ 000$ mensaes alem do ordenado do Governo.

A exemplo de outras cidades, Ribeirão Preto complementava o salário do professor normalista, porém é possível crer que se tratava de uma medida não apenas para retê-lo em sala de aula, mas também como uma forma de incentivo à frequência à Escola Normal, já que o Curso Complementar igualmente habilitava os docentes para ministrarem turmas nos Grupos Escolares.

Teoricamente, como os grupos teriam que funcionar à semelhança das EscolasModelo - modelo de modernização educacional - as quais serviam de prática para os alunos normalistas egressos, os professores que não tivessem qualquer outra formação, estariam alheios à atualização almejada do ensino, daí o incentivo financeiro para equalizá-los aos normalistas.

É preciso esclarecer que nem todos os professores recebiam críticas dos diretores como as tecidas acima. Não são incomuns elogios a muitos docentes, em particular, àqueles que se dedicam a atividades materiais, como a organização do batalhão escolar, trabalhos manuais e música, funções e matérias que, provavelmente, colocariam o grupo na berlinda:

É-me summammente grato poder continuar a informar à V.Exa . que os professores, meus subordinados, revelaram durante o anno, grande empenho em se mostrarem zelosos e dedicados no cumprimento exacto dos seus arduos deveres. Devo, entretanto, salientar os serviços extraordinarios que os distinctos professores Snr. Filinto de Mattos Brito, que foi incançavel na organisação e instrucção do batalhão escolar e nas festas escolares e Exma . Professora D. Luzia 
Fränhemhuhl, como ensaiadora de música e auxiliar de trabalhos. (Grupo Escolar de Piracicaba, 1906).

É nesse viés que se deve entender a iniciativa do diretor do Grupo Escolar Dr. Cesário Motta, de Itu, na elaboração do livro intitulado Informações Gerais sobre disciplina e conservação do material escolar, o qual continha critérios e normas para ajudar os professores a uniformizar o exercício de seus deveres e a facilitar a disciplina dos alunos no recreio. ${ }^{10}$ Não à toa, um dos capítulos do livro se refere aos prêmios e penas regulamentares aos alunos.

O material escolar também era alvo de regras. Encapar livros e cadernos, etiquetá-los, nomeá-los e descrever o estado e a data em que lhe foram entregues eram estratégias para o aluno tornar-se responsável pelo seu material, a fim de não o deteriorar alegando ser propriedade do Estado. Objetivava-se, assim, orientar as crianças a terem hábitos de ordem e economia, a desenvolverem o respeito à propriedade alheia, o sentimento de asseio e dignidade moral.

Os valores dessa conduta projetada pela escola remetem aos princípios do perfil positivista, cujo preceptor, Auguste Comte, postulava que a ação pública deveria direcionar suas iniciativas para a integração ordeira dos indivíduos no regime republicano, além de harmonizar as classes sociais com o intuito de inculcar a prática da solidariedade e do altruísmo. Os lemas propostos vinham na sequência: o Amor por princípio, a Ordem por base, o Progresso por fim. (BOSI, s/d).

As semelhanças com os valores do Positivismo não param por aí, aliás, começam antes de se mergulhar na filosofia e funcionamento dos Grupos Escolares. O destaque e a correlação já logo se imprimem na estrutura física externa dessas escolas, muito se assemelhando à arquitetura do Templo Positivista do Brasil:

\footnotetext{
${ }^{10}$ No relatório referente ao ano de 1906, encontramos o plano geral do trabalho que possui três capítulos.
} 


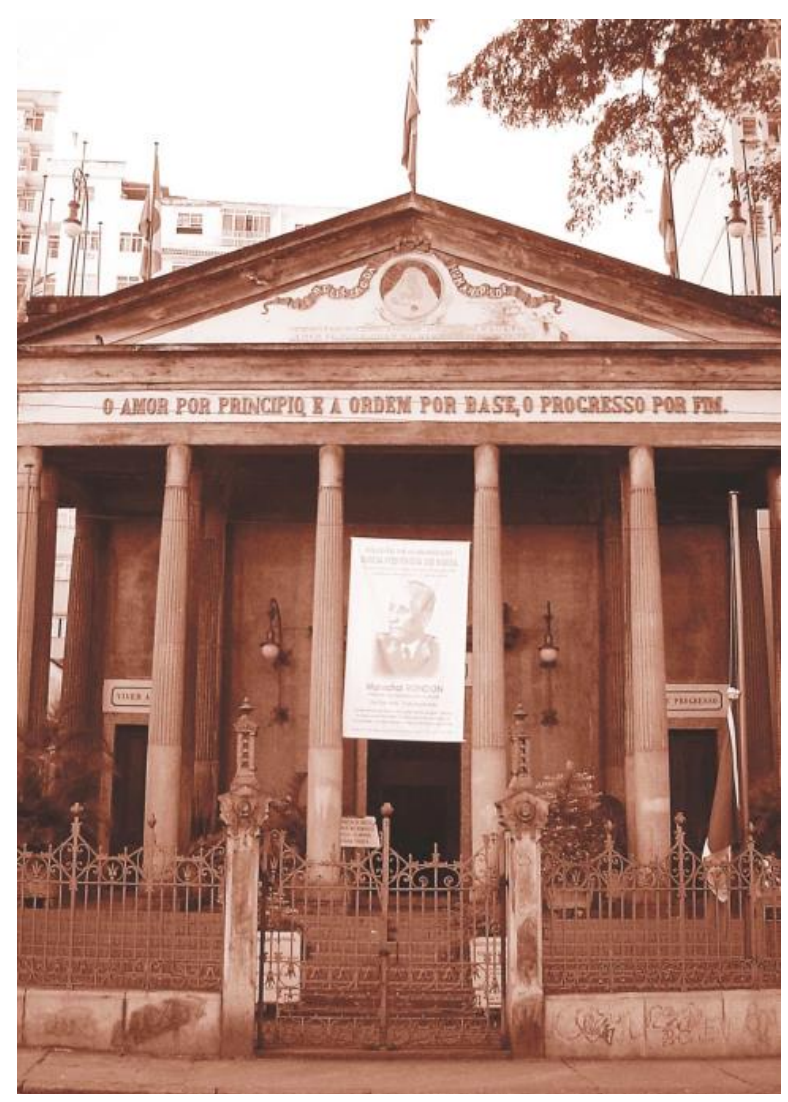

Templo Positivista no Brasil

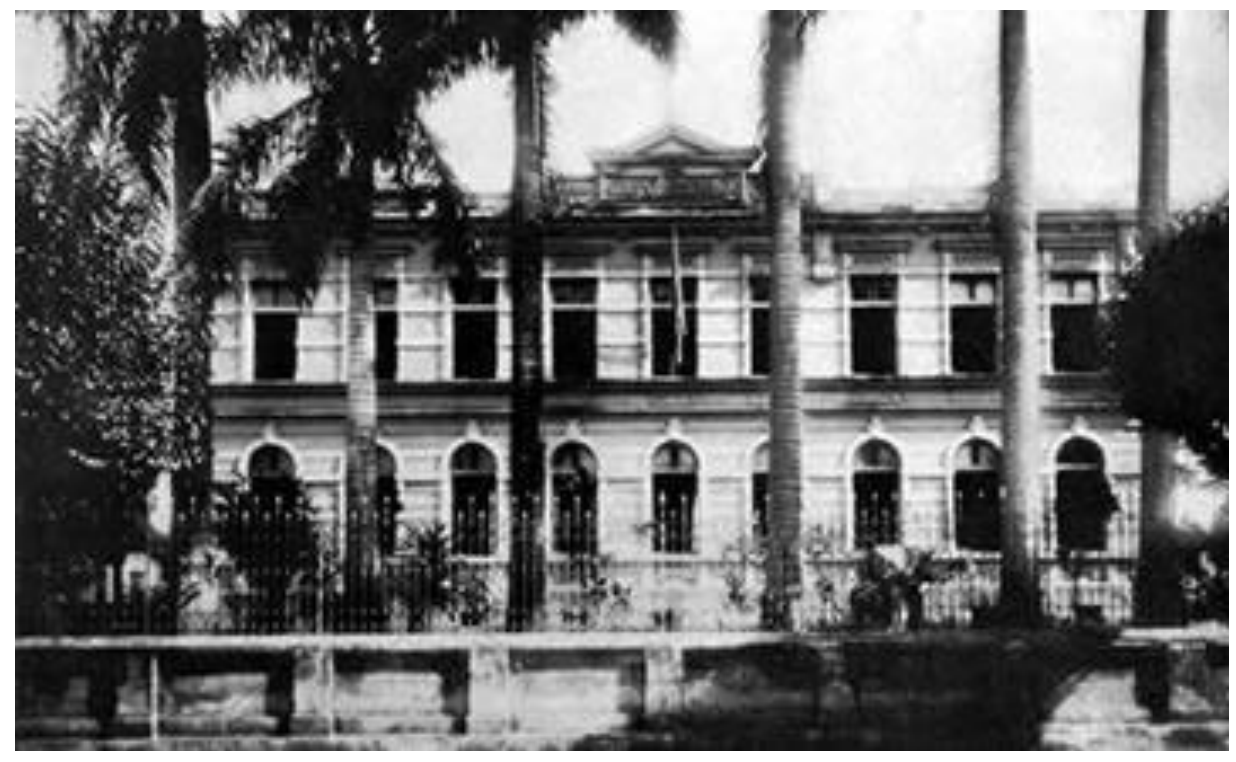

Grupo Escolar Dr. José Guimarães Júnior - Ribeirão Preto 


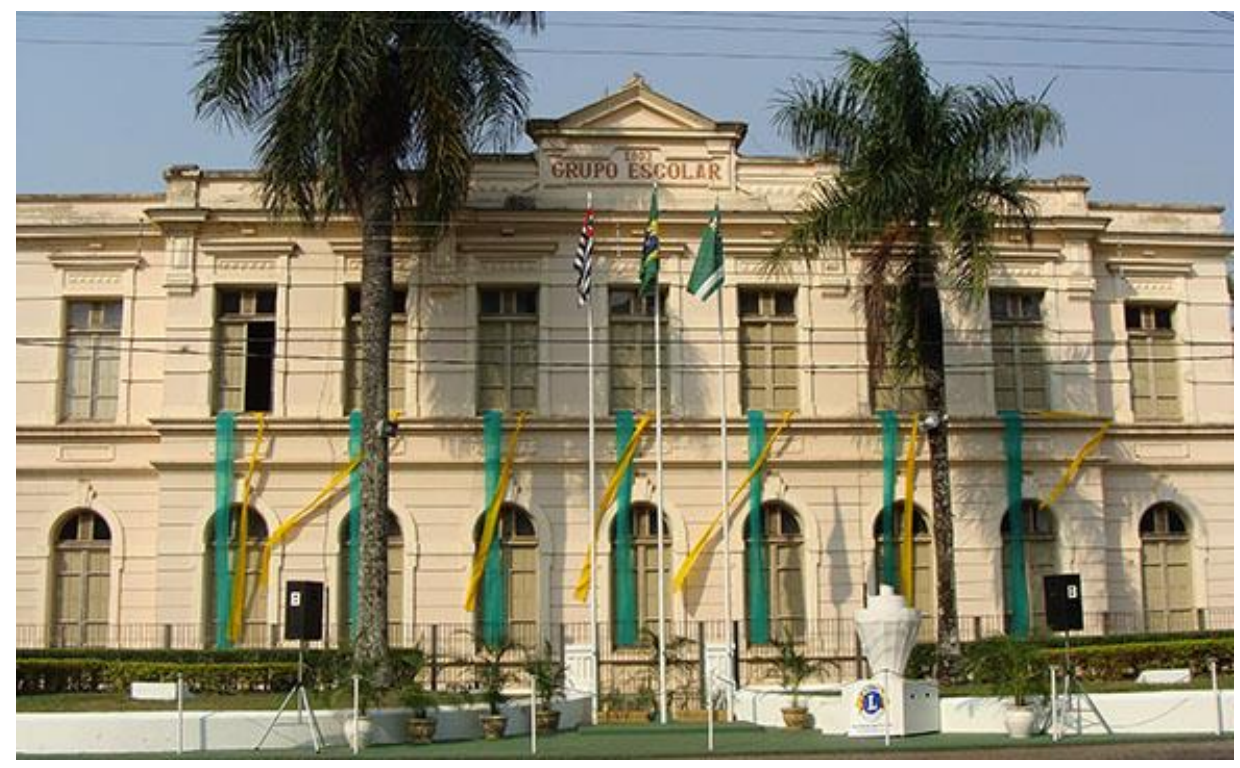

Grupo Escolar de São João da Boa Vista

O Templo Positivista possui uma estrutura similar a um Templo Dórico, cuja arquitetura de padrão clássico alcança a harmonia por meio da proporção, simetria, distribuição e, emblematicamente, a ordem de seus elementos. (SUMMERSON, 1982). Essa arquitetura que tira da ordem dórica sua inspiração, de acordo com Elias (2001), consagra a moradia do militar: Para a moradia do militar, deve-se fazer presidir um caráter marcial, anunciado por corpos retilíneos, pelos cheios quase iguais aos vazios, e por uma arquitetura inspirada na ordem dórica. (p. 80)

Por ser uma doutrina defensora do serviço militar obrigatório, essa correlação simbólica se torna uma estratégia construída para inculcar valores. Além da estrutura, os positivistas dispõem o dístico da doutrina, o Amor por princípio, a Ordem por base, o Progresso por fim, em letras formatadas no centro do frontão (triângulo) do templo.

O mesmo ocorre com os Grupos Escolares, os quais, trabalhando os conceitos positivistas-republicanos de uma herança militar, dotam seus prédios de características presentes no templo, como o frontão que, em tamanho menor, é localizado no centro do edifício, também recebem o nome da instituição (GRUPO ESCOLAR) em letras 
formatadas e encontram correspondentes elementos para substituir à colunas dóricas: as palmeiras.

Tais elementos se encontram presentes no Grupo Escolar de Bragança Paulista, um pequeno frontão no centro e acima da porta, as letras formatadas, porém as colunas naturais (palmeiras) dos grupos acima são substituídas pelas colunas do portão de entrada. As letras de forma do nome do edifício evocam a ideia de "formar almas" retas e ordeiras.

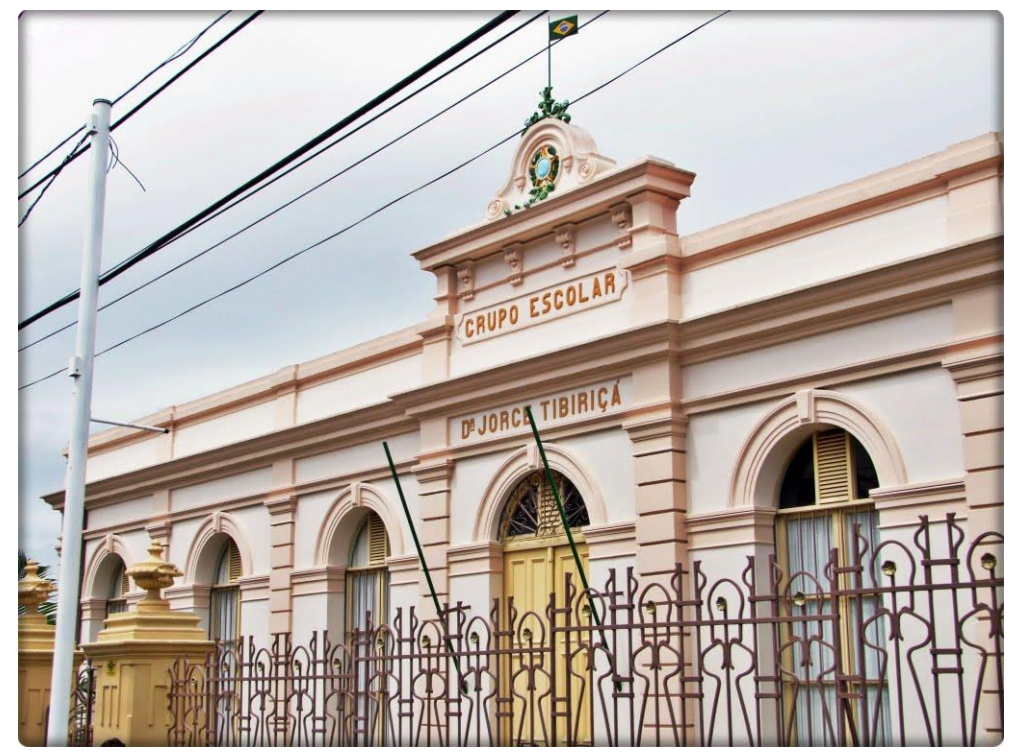

Grupo Escolar Dr. Jorge Tibiriçá - Bragança Paulista

Dessa forma, percebe-se que vários fatores operavam no imaginário escolar para incutir a ordem que o governo republicano desejava e acreditava levar ao progresso da nação. (CARVALHO, 1990). 


\subsubsection{Classe discente: a premiação nos palcos}

Uma observação atenta é capaz de revelar a condição diferente dos alunos com relação aos professores quanto aos incentivos recebidos pelo Grupo Escolar. No caso dos docentes, o único incentivo encontrado foi o auxílio financeiro dado pela Câmara Municipal de Ribeirão Preto e somente para os professores normalistas. Já os alunos eram premiados e incentivados em todos os grupos tidos como fonte para esta pesquisa.

Os prêmios foram estabelecidos notas diárias e pequenos elogios em classe, prêmio semanal, mensal, semestral e anual. O semanal consistia na inclusão, no chamado quadro de honra, dos nomes dos alunos que obtiveram boas notas de comportamento e aplicação durante a semana, os quais também recebiam, solenemente aos sábados, um distintivo usado nos domingos e devolvido aos professores na segundafeira. Já a premiação mensal dava tanto aos alunos com notas acima de 8, quanto àqueles cujos nomes estivessem no quadro de honra ou possuíssem o distintivo, cartões de aplicação e comportamento.

Com relação ao prêmio semestral, os alunos com as melhores médias nos exames eram incorporados ao batalhão escolar José Bonifácio e as meninas tinham seus nomes expostos em um quadro artístico revelado na exposição do fim do ano letivo. Por fim, anualmente, os professores de cada sala providenciavam os prêmios para serem dados aos alunos merecedores, já que nem o governo do Estado, nem a municipalidade destinavam verba para a premiação dos melhores alunos. Sobre as penalidades aplicadas, seguia-se com criterioso equilíbrio, o Regimento Interno. ${ }^{11}$

\footnotetext{
${ }^{11}$ As penas dispostas pelo Regimento Interno dos Grupos Escolares de 1904 compreendiam: repreensão, reclusão, exclusão da aula ou do recreio, exclusão do quadro de honra, suspensão de até 15 dias e eliminação. Eram impostas pelos diretores e as três primeiras poderiam ser dadas pelos próprios professores por mau comportamento. A aplicação das penas seria determinada com prudência $e$ moderação e de acordo com a gravidade da falta cometida pelo aluno. A suspensão e eliminação só seriam praticadas depois de esgotados todos os recursos mais brandos.
} 
Com esses estímulos dados aos alunos, deu-se início ao que se denominou de pedagogia dos prêmios que, além dos adotados oficialmente por todos os grupos certificado de habilitação e diploma de conclusão do ensino preliminar, muitos diretores distribuíam cartões de promoção e recompensas diárias para os alunos que tiravam as melhores notas de aplicação e comportamento, as quais eram expostas em quadros de honra que, muitas vezes, eram publicados na imprensa local:

No intuito de estimular as creanças ao estudo, realisei diversos concursos entre alumnos da mesma classe e institui premios com denominações diversas.

[...]

No acto foram offertados outros premios aos jovensinhos compeões das letras $[\ldots]$

[...]

Tambem pus em pratica, com muito bom resultado - a collocação dos nomes dos alumnos que mais se distinguiram durante o mes, no "Quadro de Honra", publicando o resultado pela imprensa local.

Os cartões de merito e recompensas diárias, que distribúo aos alumnos, tem valor apenas em começo: depois, pouco importancia elles ligam, desde que não se valorisa-as por meio de leilões de prendas. (Grupo Escolar de São José dos Campos, 1906).

A princípio, a premiação servia de estímulo aos estudos, mas, a partir do momento em que os prêmios passavam a não motivar mais as crianças, o diretor recorria a sorteios de prendas para ganhar a atenção discente de novo:

[...] a sessão de encerramento dos trabalhos escolares constou apenas de distribuição de boletins de promoção e de certificados de habilitação as alumnas que concluiram o curso preliminar [...] e ainda de premios aos alumnos mais distinctos. (Grupo Escolar de São Luiz do Paraitinga, 1906).

Paralelamente à adoção do processo da pedagogia dos prêmios, a evasão e reprovação escolar surgiram como problemas graves. A reprovação é, constantemente, justificada pela transferência do aluno de uma escola isolada, o qual demonstrava dificuldade para acompanhar o programa:

As principaes causas do pequeno adiantamento dos alumnos foram: escassez de tempo para a execução do programma e desigualdade na classificação dos alumnos das escolas isoladas anexadas ao Grupo. 
[...] tornou-se necessária a reprovação da maioria dos alumnos, visto como, os programmas de diversos annos não foram completamente desenvolvidos, como se verifica da primeira afirmação.

Entretanto, algumas promoções foram feitas com o fim unico de corrigir defeitos da uniformidade de adiantamento. (Grupo Escolar Edmund Trench - Avaré, 1906).

O baixo rendimento levava o aluno à reprovação escolar devido ao seu pequeno adiantamento, em outras palavras, a dificuldade em contornar o ajuste e divisão dos discentes em séries levava à aprovação dos mais preparados e a reprovação dos menos preparados. Ao invés de desenvolver e reforçar o conhecimento dos reprovados, a conduta apontada revela a possível formação de um conjunto desmotivacional.

Já a evasão acontecia pela necessidade de acompanhar os pais que se deslocavam para as fazendas de café em busca de trabalho no período da colheita:

Eliminei durante o anno 112 alumnos, o que fas admirar tão consideravel numero de eliminados, porem, a rasão é obvia; V. $\mathrm{Ex}^{\mathrm{a}}$. Melhor do que eu conhece o norte S. Paulo - e sabe perfeitamente que a população das cidades é constituída em sua maioria por pessoas pobres, de maneira que chegada a occasião da colheita de café, todos procuram as fazendas agricolas com o fim de ganharem o pão e consigo levam as creanças, o que dá em serem elimnados após 30 dias de faltas. (Grupo Escolar de São José dos Campos, 1906).

Além desses alunos eliminados, as transferências de alunos vindos das escolas isoladas eram desvantajosas aos olhos dos diretores. Alvos de preconceito, eles tinham suas inclusões à escola consideradas embaraçosas para o funcionamento do grupo:

[...] não convém ao Estado pela morosidade que elas [as transferências] apresentam no preparo de alumnos. [...] forçoso é reconhecer que no interior do estado as escholas isoladas não preenchem satisfatoriamente o fim, devidos as difficuldades que constantamente embaraçam seu regular funcionamento. (Grupo Escolar Cesário Motta - Itu, 1906).

Não apenas os alunos vindos das escolas isoladas sofriam certo tipo de rejeição,

mas também aqueles filhos de pais menos abastados que eram vistos de uma forma diferente:

No geral, os alumnos são filhos de proletarios e de outras familias menos abastadas, rasão porque com mais ardor devemos ministrarlhes o ensino, olhando-os com carinho. A elles com mais rasão 
pertence o patriotico intuito do benemerito governo do Estado, diffundindo profusamente o ensino gratuito, pois, os diminutos e escassos recursos dos seus progenitores não permittem o acesso a collegios particulares e escolas profissionais. (Grupo Escolar de São José dos Campos, 1906).

Do excerto acima, podemos aferir que havia também alunos provenientes de classes sociais inferiores, porém, como não foi possível identificar o perfil dos alunos, não se pode afirma, com precisão, suas origens.

É provável que grande parte do público atendido pelos Grupos Escolares não fosse formado por poderosas famílias de proprietários rurais paulistas e sim por um setor da população urbana que se compunha tanto de pequenos proprietários, profissionais liberais, jornalistas, professores e estudantes (CARVALHO, 1990), como do proletariado.

Ainda que algumas classes sociais dentro dos grupos fossem desfavorecidas, cabe argumentar, sugestivamente, que a maior preocupação, então, não era dar adequada instrução para a população e sim criar uma atmosfera simbólica capaz de dar visibilidade ao novo governo para o público externo por meio da bandeira da Instrução Pública.

\subsection{O arsenal da propaganda: exames e festas cívicas}

Os Grupos Escolares instituíram um programa baseado na formação de classes graduadas, as quais para evoluírem de um estágio a outro, exigiam um constante processo de avaliação e seleção. Dessa forma, surgiram os exames públicos no final dos anos letivos, com banca examinadora composta pelo inspetor do distrito, duas pessoas nomeadas por ele e o professor do aluno em avaliação. (SOUZA, 2005).

Entretanto, na prática, os próprios diretores examinavam os alunos com auxílio de um ou dois professores do grupo: 
O julgamento foi feito pelo director e os dois professores das respectivas classes.

O exame oral feito pelo professor da classe e pelo director.

Afim de attrahir ao grupo pessoas gradas fiz officios convidando todas auctoridades locais para servirem de examinadores, não sendo, entretanto julgadores ou arbitros, si assim posso me expressar.

Essas pessoas raramente fariam uma ou outra pergunta ao examinando. (Grupo Escolar Dr. Cesário Motta - Itu, 1906).

Pessoas de projeção da cidade e do estado eram convidadas a participar do evento, pois os exames, na maioria das vezes, eram revestidos de grandes solenidades. Tais exames consistiam em atividades sistemáticas e contínuas do ensino primário, sujeitos a uma série de normatizações, pois compreendiam provas escritas (ditado, composição e questões práticas de aritmética), práticas (caligrafia e desenho) e orais (todas as outras matérias, exigindo ritmo, melodia, entonação, postura corporal e desenvoltura).

O Grupo Escolar Cel. Vaz, de Jaboticabal, por exemplo, recebeu, como presidente da banca examinadora, o inspetor René Barreto. Já o Grupo Escolar de Ribeirão Preto contou com a presença do médico Luiz Pereira Barreto, ${ }^{12}$ do inspetor, do prefeito e de personalidades da cidade:

Snrs. Dr. Luiz Pereira Barretto, Dr. Enéas da SANTOS SILVA, Dr. Augusto Ribeiro de Loyolla, Dr. Macedo Bittencourt, Dr. Rocha Fragoso, Dr. Abílio Sampaio e Dr. Fabio Barretto. (Grupo Escolar de Ribeirão Preto, 1906).

Como, muitas vezes, pessoas consagradas e famílias da sociedade local prestigiavam os exames dos Grupos Escolares, tais eventos se tornavam símbolos de projeção republicana tanto da própria escola como das figuras políticas da cidade, pois além de enaltecer a atuação dos melhores alunos, servia de propaganda para futuras eleições da cidade.

\footnotetext{
${ }^{12}$ Giovanna Ike Coan, em busca de fontes para sua dissertação de mestrado, encontrou, na revista $A$ Cigarra (ano VII, n. 129, 1920), um anúncio publicitário de uma bebida formulada pelo médico, a qual prevenia algumas doenças. Isso, juntamente com os dizeres Formula do eminente Sábio Dr. L. P. Barreto, evidenciam a importância que Pereira Barreto tinha na época. Além disso, ele tentava estabelecer como programa a organização sociedade civil com acento na educação e não na política. (ALONSO, 1995).
} 
Além disso, outros artifícios foram adotados e obtiveram o mesmo tipo de vantagem funcional, como o orfeão escolar e o ensino da música, especialmente, os cantos pátrios e folclóricos e as canções produzidas pelos alunos em homenagem à escola.

Os diretores promoviam festejos em datas cívicas para ressaltar a pátria por meio de passeios pela cidade com saudações às autoridades municipais, sessões literárias, apresentações musicais dos hinos nacional, da bandeira, da república e dos próprios grupos. ${ }^{13}$ Como datas cívicas, o Grupo Escolar Dr. Jorge Escolar Tibiriçá, de Bragança, comemorou, durante o ano, as datas de 3 de maio, 7 de setembro e 15 de novembro:

Durante o anno lectivo findo tenha a registrar 3 festejos escolares: a commemoração civica de 3 de Maio onde depois de uma sessão literária o Grupo realisou uma passeiata, saudando as autoridades locaes; a de 7 de Setembro, em homenagem a Independência do Brasil, sendo por essa occasião inaugurado o estandarte do Grupo que foi adquirido sem o producto de uma subscripção feita entre alumnos e professores; a de 15 de Novembro lançamento da pedra angular do novo predio escolar. (Grupo Escolar Dr. Jorge Escolar Tibiriçá Bragança, 1906)

Já no Grupo Escolar Cel. Vaz, de Jaboticabal, as datas de 13 de maio e 7 de setembro foram comemoradas também na presença de autoridades municipais:

As datas nacionaes - 13 de Maio e 7 de Setembro foram solennemente festejadas neste estabelecimento. As nossas festas que constaram de sessções civicas em que tomaram parte os professores e alumnos, compareceram as auctoridades municipaes, representantes consulares, associações particulares e muitas familias. As de 7 de Setembro, principalmente, revestiu-se de grande brilho e foi verdadeiramente popular.

Não temos poupado esforços no sentido de dar á mocidade escholar uma educação cívica esmerada, pois, pensamos tambem, que um povo sem civismo é incapaz de lutar pela sua liberdade.

Desse modo, as armas simbólicas eram postas em uso, hinos e comemorações cívicas eram largamente difundidos pelos Grupos Escolares como forma de despertar o sentimento pátrio nos pequenos cidadãos. Procurava-se, assim, traduzir o sentimento

\footnotetext{
${ }^{13} \mathrm{O}$ regimento de 1904 não dispunha de quais datas cívicas deveriam ser comemoradas, apenas trazia que Na vespera dos dias de festa nacional cada professor fará, no ultimo quarto de hora, prelecção a respeito da data que se vai commemorar. (art. 25)
} 
coletivo e a emoção cívica dos membros de uma comunidade nacional. (CARVALHO, 1990).

Buscando refazer o imaginário nacional e enraizar solidamente o amor pelo novo governo, esse processo funcionava como objeto de projeção para o público externo aos grupos no começo do século XX.

\section{Considerações finais}

A tarefa dos republicanos era substituir um governo e construir uma nação, porém a República brasileira foi proclamada em uma sociedade na qual a desigualdade imperava ao lado da hierarquização das classes. O momento de grande especulação financeira, motivado para atender as necessidades políticas da abolição da escravatura (preservação da ordem nacional e atração mão-de-obra imigrante para os cafezais), era incompatível com os valores republicanos. (idem, ibidem)

Era impossível enxergar o interesse público como a soma dos individuais, pois não havia preocupação alguma com o público e, para que a situação mudasse, deveria haver uma identificação coletiva, sentimento de pertencer a uma nação que o Brasil em questão não possuía. Juntamente a essa falta de identidade, a ausência de envolvimento popular resultou em um empecilho para a construção de um contexto republicano que fosse capaz de persuadir prontamente a população.

Para a tarefa do convencimento, não só a palavra falada e escrita foi utilizada, mas também a batalha simbólica, cuja importância adquiriu centralidade no período e, devido à carência de um civismo republicano, firmou raízes fora da política. De acordo com Carvalho, nos casos em que a ação política se apoiou nas tradições populares, 
cabe-lhes o mérito de ter contribuído de maneira substantiva para a construção do pouco que subsistiu de imaginário republicano. (ibidem, p.140)

Por surgirem a partir da reunião de outras escolas existentes no raio fixado para a obrigatoriedade do ensino, instituírem o sistema de premiação e as festas cívicas, os Grupos Escolares foram mais uma forma de trabalhar o imaginário popular, dando visibilidade à formatação - e não à formação - e à reunião de um grupo de crianças que, simbolicamente, representariam a união e a ordem tão almejadas e necessárias à construção da nação republicana. 


\section{Capítulo 2 - Expansão dos Grupos Escolares: difusão da norma linguística}

\section{Introdução}

Este estudo traça suas linhas investigativas em um período de transformações sociais, políticas e econômicas no Brasil, primordial para a formação do português brasileiro: a virada do século XIX. Esse momento se caracteriza por uma gama de discussões linguísticas, no qual se estabelece um processo de reformulações de normas gramaticais, cuja variedade brasileira já evidenciava diferenças estruturais com relação à portuguesa. (TARALLO, 1993).

O reflexo desse embate político-gramatical que atingiu as gramáticas normativas tem sido associado à proposta de civilização do país sustentada pelas elites, grupo que teria buscado no português europeu moderno um modelo de língua inacessível às classes mais baixas, o que resultaria em uma unidade normativa com Portugal (PAGOTTO, 1998).

A passagem do século XIX para o XX é conhecida pelas discussões em torno da colocação pronominal, tendo por protagonistas José de Alencar no final do período monárquico e Rui Barbosa no exórdio do governo republicano, por ocasião da aprovação do primeiro Código Civil Brasileiro, de autoria de Clovis Bevilacqua, do qual Rui Barbosa foi parecerista.

Entre os contextos tomados como alvo de críticas nos dois casos está a oração subordinada, para a qual a gramática prescreve o uso da próclise, e os verbos não flexionados regidos por preposição a qual é determinante do tipo de colocação pronominal. O uso enclítico nesse ambiente por José de Alencar, como em parece que 
cerra-se, e resgatado por Bevilacqua gera acirradas polêmicas, envolve o gramático baiano Carneiro Ribeiro que alegava que os clássicos também adotavam essa colocação.

Pagotto (2011) mostra a incoerência da atitude de Rui Barbosa, tendo em vista que em parecer de 1883 sobre a Reforma do Ensino Primário, o jurista repudiava o estudo da gramática. Em atitude contrária ao seu parecer e aos próprios usos, ele apelava para a gramática normativa, considerada uma ação disciplinadora da ciência, da aplicação metódica de princípios. (p.15)

A colocação pronominal em contexto de operador é também tratada pelo gramático português Júlio Moreira que atesta o uso da ênclise no português do Brasil lá onde os portugueses colocariam a próclise:

Como se sabe, no português do Brasil é frequente colocarem-se na frase os pronomes pessoais complementos de modo muito diverso daquele que em Portugal usamos. Assim dizem: 'o livro que você deu-me', _'quem disse-te isso?", _quem viu-te?', _'não chamou-me', _'não enganava-se', _'nunca viram-te', etc. (MOREIRA, 1913: 97).

Para verificar o alcance da ênclise no contexto de operador, Schei (2003) analisou a colocação pronominal nos romances de J. Macedo, José de Alencar e Bernardo Guimarães, atestando o uso dessa colocação nas orações subordinadas. Oliveira (2011), por sua vez, analisou a colocação pronominal nas subordinadas em cartas pessoais de Álvares de Azevedo, Machado de Assis e Lima Barreto. A autora observou a sua presença nos três autores, mas com baixa produtividade: na amostra do primeiro escritor, a ênclise atinge os 13.25 pontos percentuais, mas nos demais não chega a 1\%:

Tabela 1. Próclise em orações subordinadas de escritores brasileiros

\begin{tabular}{|ll|ll|ll|}
\hline \multicolumn{2}{|c|}{ Álvares Azevedo } & \multicolumn{2}{|c|}{ Machado de Assis } & \multicolumn{2}{|c|}{ Lima Barreto } \\
\hline $131 / 151$ & $86.75 \%$ & $365 / 366$ & $99.76 \%$ & $179 / 180$ & $99.44 \%$ \\
\hline
\end{tabular}


Aparentemente, os dados numéricos mostram que os escritores do final do século estão mais atentos à prescrição gramatical. Entretanto, não se pode esquecer de que a próclise se generalizava em todos os contextos linguísticos no vernáculo brasileiro, de modo que a próclise na subordinada nas cartas desses escritores acompanhasse essa tendência.

Por sua vez, os escritores com passagem pela Academia de Direito do Largo de S. Francisco (Bernardo Guimarães, José de Alencar e Álvares de Azevedo) apresentam usos mais frequentes da ênclise, o que pode sinalizar que essa colocação fosse um marcador social dos bacharéis.

A análise desse mesmo contexto por Santos Silva (2012) demonstra que a escrita dos intelectuais republicanos paulistas não segue a norma europeia, pois se caracteriza como um domínio sintático permeado pela ênclise. Desse estudo que evidencia a prevalência enclítica do pronome nas orações subordinadas, mesmo sendo um âmbito em que o português oral do Brasil e o português europeu preferem a próclise, a autora delineia uma gramática enclítica na escrita desses intelectuais.

Considerando a colocação pronominal em subordinadas dos ofícios e relatórios dos Grupos Escolares paulistas, contata-se que, em geral, a ênclise tem frequência bem inferior à próclise no contexto de subordinadas:

Tabela 2. Distribuição de próclise e ênclise em subordinadas por cidade ${ }^{14}$

\begin{tabular}{|l|l|l|l|l|l|l|l|l|l|l|l|l|l|l|l|l|l|l|}
\hline & AV & BP & CP & GU & IP & IT & JB & JU & LE & LI & MO & MM & PI & RP & SJ & SL & SM & SS \\
\hline P & 4 & 3 & 3 & 2 & 8 & 6 & 1 & 2 & 4 & 6 & 10 & 1 & 14 & 21 & 13 & 7 & 11 & 12 \\
\hline
\end{tabular}

\footnotetext{
${ }^{14} \mathrm{P}$ - próclise; E - ênclise; AV- Avaré; BP - Bragança Paulista; CP - Campinas; GU - Guaratinguetá; IP - Itapira; IT - Itu; JB - Jaboticabal; JU - Jundiaí; LE - Leme; LI - Limeira; MO - Mococa; MM - Mogi Mirim; PI - Piracicaba; RP - Ribeirão Preto; SJ - São José dos Campos; SL - São Luiz de Paraitinga; SM - São Manoel do Paraíso; SS - São Simão.
} 


\begin{tabular}{|l|l|l|l|l|l|l|l|l|l|l|l|l|l|l|l|l|l|l|}
\hline $\mathrm{E}$ & - & 1 & 1 & - & - & - & - & - & 5 & 7 & - & - & 1 & - & - & - & 1 & - \\
\hline
\end{tabular}

Seguem alguns exemplos:

(1) Esta ultima professora que acha-se em goso de licença é substituída por Fausta Stachler (Grupo Escolar Dr. Jorge Escolar Tibiriçá - Bragança Paulista, 1906).

(2) Em substituição ao Sr. Joaquim Firmino da SANTOS SILVA, que exonerara-se a pedido ( $1^{\circ}$ Grupo Escolar de Campinas, 1906).

(3) A servente que, por moléstia, affastara-se do exercício de seu cargo até 15 de Setembro (Grupo Escolar Cel Augusto César - Leme, 1906).

(4) A primeira foi por 90 dias, concedida ao adjuncto Sr. Professor Adelino Mello que gosou-a de 2 de Fevereiro a 4 de Maio (Grupo Escolar Cel Augusto César Leme, 1906).

(5) Por algumas vezes foi o Grupo visitado por pessoa suspeita, que limitava-se a furtar relogios etc. (Grupo Escolar Cel Augusto César - Leme, 1906).

(6) Assumiu a direção do grupo o inspector escholar que inaugurou-o solennemente

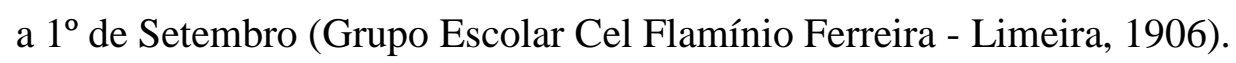

(7) [...] durante o anno lectivo que encerrou-se a 30 de Novembro ultimo (Grupo Escolar Cel Flamínio Ferreira - Limeira, 1906).

(8) Explicava os motivos que pareciam-me razoaveis (Grupo Escolar Cel Flamínio Ferreira - Limeira, 1906). 
(9) Existem 8 salas destinadas aos annos do Grupo, dentre as quaes consideram-se duas (Grupo Escolar Moraes Barros - Piracicaba, 1902).

$$
\text { O } 4^{\circ} \text { anno que satisfez-me plenamente (Grupo Escolar Dr. Augusto Reis }
$$

- São Manoel do Paraíso, 1906).

Salta aos olhos o caso de Leme e Limeira em que a ocorrência da ênclise supera a da próclise. Essa colocação é emblemática nessa região, que recebeu os primeiros colonos portugueses aliciados principalmente na Ilha dos Açores na primeira metade do século XIX, para trabalharem ao lado de colonos suíços e alemães, em sistema de parceria na fazenda Ibicaba do senador Nicolau Vergueiro. (COSTA, 2010).

Como a próclise é característica dessa variedade linguística no contexto de oração subordinada, como o atesta o gramático da época Júlio Moreira, o uso da ênclise pode estar indiciando o repúdio aos portugueses ou mesmo à monarquia, visto que a regência era da família Bragança, e, por contraponto, a adesão ao governo republicano. Com efeito, Leme e Limeira se acham incluídas nas áreas de emprego de ênclise também no contexto das infinitivas preposicionadas, como mostra o mapa 2, ao final do capítulo, o qual traz o padrão linguístico dos Grupos Escolares paulistas.

Esses dados sugerem que a ênclise que se firma na modalidade escrita brasileira não corresponde àquela usada pelos portugueses, o que nos leva a afastar a hipótese de que a variedade europeia do português era tomada como modelo pela elite brasileira.

\section{Contextualizando a análise linguística}

O intervalo histórico em questão, juntamente com suas respectivas modificações linguísticas, é abordado por diversos trabalhos de sintaxe diacrônica, alguns dos quais são pontos de partida para nossa investigação. (PAGOTTO, 2012; OLIVEIRA, 2011; 
SANTOS SILVA, 2012). No final do século XIX, um processo de mudança na posição do clítico em orações infinitivas preposicionadas se instaura no português brasileiro culto, o qual se distancia tanto do padrão lusitano como do uso vernacular da época. Essas diferentes colocações são motivos de controvérsia entre os intelectuais.

A ordenação dos pronomes, polemizada por Rui Barbosa ao travar sua discussão sobre as questões linguísticas do Código Civil escrito por Clóvis Bevilácqua em 1902, ganha destaque e evidencia que o padrão adotado por Rui se contrapunha aos dados de intelectuais paulistas e escritores brasileiros, os quais acompanham a mudança de uma gramática brasileira enclítica para uma proclítica, característica do vernáculo. (OLIVEIRA, 2011).

Oliveira (2013), analisando cartas advindas de aldeamentos paulistas e de diferentes regiões brasileiras escritas entre 1820 e 1910, observa que a escrita de correspondência pública do século XVIII se aproxima da gramática portuguesa que seleciona ênclise com a preposição $a$ e próclise com as demais preposições, mas a do século XIX se afasta dela por adotar a ênclise generalizada.

O processo enclítico ganha forças na produção de intelectuais paulistas, membros da elite sócio-política (Prudente de Moraes, Campos Sales e Rodrigues Alves, entre outros), os quais além de também não seguirem o padrão português, configuram a ênclise nos diversos contextos sintáticos como condicionante capaz de distinguir classes sociais. (SANTOS SILVA, 2012).

No início da Primeira República, portanto, concorriam três regras:

1. as que configuram o modelo português, em que a ênclise é redutível à presença da preposição $a$ :

Ex. começou a dizer-lhe; depois de lhe dizer; para lhe dizer 
2. as que se aproximam do vernáculo brasileiro, em que se privilegia a próclise generalizada:

Ex. começou a lhe dizer; depois de lhe dizer; para lhe dizer

3. as que se encaixam em um contexto, predominantemente, enclítico como marcação distintiva da elite político-econômica:

Ex. começou a dizer-lhe; depois de dizer-lhe; para dizer-lhe.

O contexto republicano pressupõe um jogo de forças sócio-políticas operantes no processo civilizatório do país que se apoia na expansão das instituições de ensino como importante vetor na modernização brasileira almejada. $\mathrm{Na}$ esfera educacional, identificamos a busca pela construção de um sistema de ensino unificado nacionalmente que encontra nas escolas ferramenta para dar maior visibilidade às iniciativas governamentais.

Além da repaginação da Escola Normal e instauração da Escolar-Modelo anexa, os republicanos lançam os Grupos Escolares como legítima criação, a qual serve de meio propagandístico para o modelo do governo instaurado. A descentralização justificada pelo novo governo delegava como responsabilidade dos estados a provisão do ensino público por meio da abertura de escolas primárias.

Tal fato fez com que São Paulo iniciasse o processo devido a sua hegemonia política e econômica, o qual cria os Grupos Escolares como reflexo da instauração da escola graduada nos países europeus na tentativa de acompanhá-los no caminho do progresso.

Essa implantação começou em 1893 e abarcou, inicialmente, a faixa que se estende de Lorena, localizada no extremo Vale do Paraíba, a Avaré, situada no Oeste 
Paulista Velho, cujos grupos foram instalados entre 1893 e 1899, e caminha, cronologicamente, por Campinas até alcançar o coração do Oeste Paulista Novo, Ribeirão Preto, trecho no qual os grupos foram criados de 1900 a 1907. Tal processo é evidenciado no mapa abaixo:

Mapa 1. Movimento de implantação dos Grupos Escolares paulistas

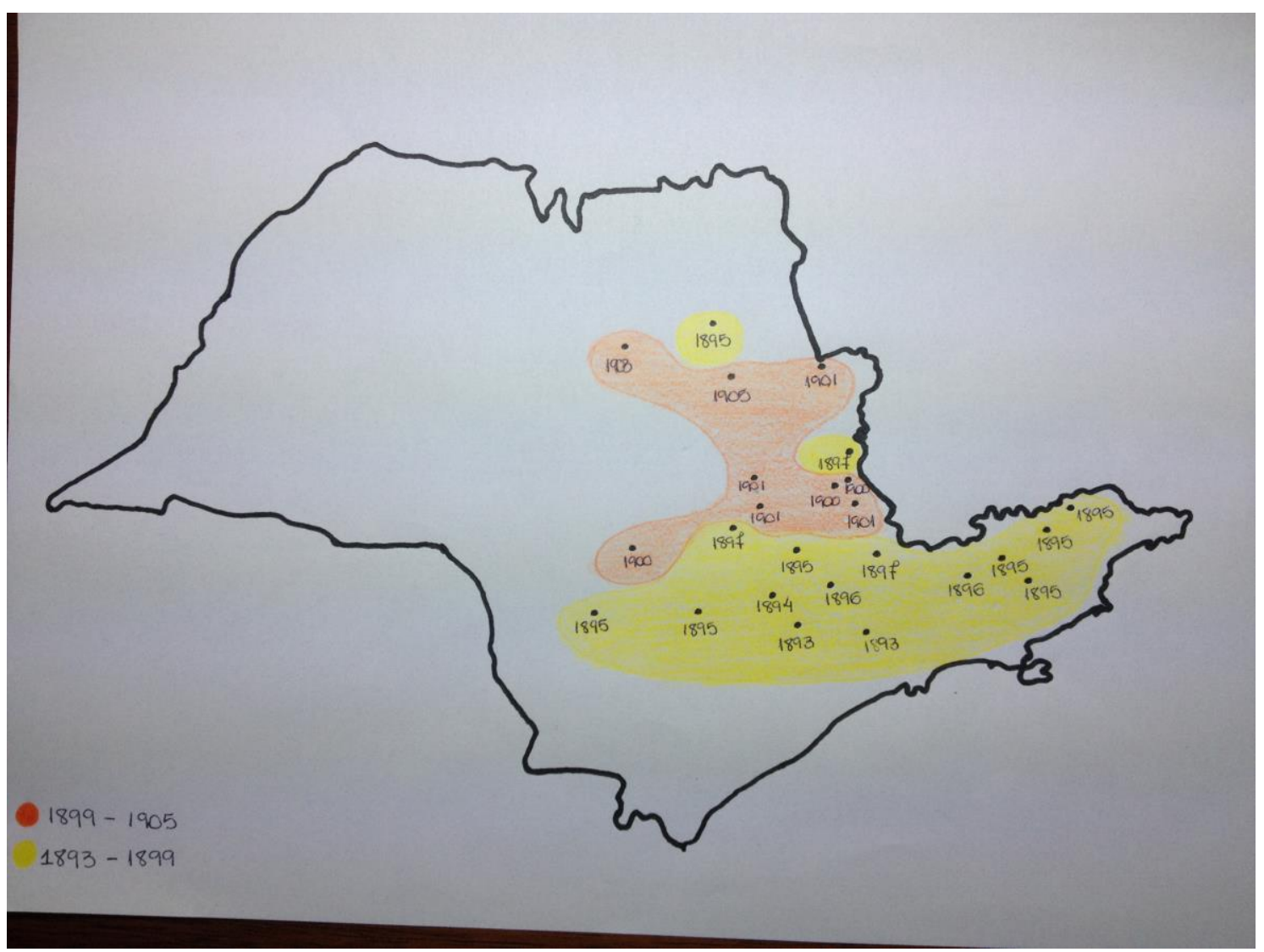

Assim, o objeto de análise desta pesquisa se justifica pela importância adquirida no período, já que nosso corpus se constitui de textos de estilo formal de elaboração compostos por ofícios e relatórios escritos em 1902 e 1906 por diretores dos Grupos Escolares e inspetores da educação do estado de São Paulo. 
Esses documentos ${ }^{15}$ são sempre endereçados ao secretário do interior para prestar contas sobre o movimento dos Grupos Escolares. Mas, por meio de carimbos e assinaturas, evidenciamos que, na verdade, o órgão que recebia esses ofícios e relatórios era a chamada Diretoria do Interior e quem, oficialmente, respondia era a Subdiretoria, mais especificadamente, os chefes-interinos da $1^{\mathrm{a}}, 2^{\mathrm{a}}$ e $3^{\mathrm{a}}$ seções, cuja hierarquia era respeitada de acordo com a gravidade do problema apontado.

O gênero textual ofício pertence ao grupo de textos denominados mais padronizados e estereotipados, que seguem um modelo mais rigoroso de produção, e possui a função social de permitir a troca de informações - assuntos administrativos ou estabelecimento de ordens - entre pessoas e/ou autoridades institucionais. Nele, há descrição, detalhamento de processos, narração de fatos, argumentação necessárias ao contexto delimitado etc. (FERREIRA, 2006).

Os ofícios analisados neste trabalhado enviavam informações de diversas ordens para o secretário do interior - comunicação entre autoridades, desde simples avisos anexos à folha de pagamento do mês até sugestões de nomeação de professores:

Exmo. Snr.

Incluso transmittir-vos as folhas de pagamento do pessoal do grupo sob minha direcção referente à Dezembro e Janeiro ultimos.

Saúde e Fraternidade.

Ao Exmo. Snr. Dr. Bento Bueno

Secretario de Estado dos Negocios do Interior

O director

(Grupo Escolar de São Luiz do Paraitinga - 1902)

\footnotetext{
${ }^{15}$ Documentos encontrados no Arquivo Público do Estado de São Paulo. Estão divididos em duas latas: a primeira, nomeada Secretaria do Interior - Grupo Escolar (1902-1904) - Relatórios - CÓDIGO = CO6932, é composta por ofícios e relatórios redigidos pelos diretores desses grupos. Na segunda, intitulada Secretaria do Interior - Instrução Pública (1906) - Relatórios - CÓDIGO = CO6935, encontramos tanto relatórios desses mesmos diretores, como os elaborados pelos inspetores educacionais do estado que fiscalizavam os municípios a eles encarregados.
} 
Já os relatórios são considerados gêneros que exigem a capacidade de expor, relatar, sistematizar e argumentar, tendo por base uma interação social com um destinatário. Nos relatórios estudados, endereçados também ao secretário do interior, há o detalhamento do movimento de alunos (matrícula, frequência, aprovações e eliminações) e de professores (nomeações, exonerações, frequências e licenças) durante o ano. Trata ainda de comemorações cívicas, exposições de trabalhos manuais, festas de encerramento, visitas de autoridades da época e as condições, geralmente, precárias, das salas de aula, da mobília escolar, do material didático, e, até mesmo, da falta de professores:

Relatorio apresentado pelo Director do Grupo Escholar "Coronel Vaz" de Jaboticabal, ao Excellentissimo Senhor Doutor Gustavo de Oliveira Godoy - D.D. Secretario dos Negocios do Interior, na forma do art. $81 \S 15$ do Regimento Interno.

Excellentissimo Senhor

[...] As datas nacionaes - 13 de Maio e 7 de Setembro foram solennemente festejadas neste estabelecimento. As nossas festas que constaram de sessões civicas em que tomaram parte os professores e alumnos, compareceram as autoridades municipaes, representantes consulares, associações particulares e muitas famílias. As de 7 de Setembro, principalmente, revestiu-se de grande brilho e foi verdadeiramente popular.

(Grupo Escolar de Jaboticabal - 1906)

Produzidos no âmbito de 36 Grupos Escolares da cidade de São Paulo e do interior paulista, os ofícios e relatórios em questão se encontram disponíveis no Arquivo Público do Estado de São Paulo, como mencionado no capítulo 1.

Textos oficiais, pelo seu caráter formal, pressupõem o uso do português culto, o qual, no final do século XIX, se reformulava. Tendo em vista, nesse momento, a gramática enclítica dos intelectuais republicanos paulistas (SANTOS SILVA, 2012) e o crescimento da posição proclítica do vernáculo brasileiro (OLIVEIRA, 2013), o eixo central da nossa investigação é identificar se os Grupos Escolares paulistas possuem um 
único padrão linguístico quanto à colocação pronominal em orações com verbos infinitivos regidos por preposição e qual seria esse padrão.

O trabalho toma como modelo teórico-metodológico a sociolinguística variacionista (LABOV, 2008), procurando observar fatores condicionadores das variantes. Abordaremos as ocorrências linguísticas a partir de critérios linguísticos e extralinguísticos. Como foram levantadas colocações pronominais em expressões formulaicas e expressões abertas, ${ }^{16}$ esse fator será levado em consideração, assim como o tipo de verbo, de preposição e de pronome. Nosso intuito era dar tratamento estatístico das ocorrências por tipo de texto, ofícios e relatórios, entretanto, devido à escassez dos dados levantados, optamos por uma análise qualitativa, considerando os condicionamentos linguísticos e extralinguísticos que influenciam a colocação pronominal.

Para isso, após uma análise linguística preliminar, abordaremos tais ocorrências pelo paradigma indiciário proposto por Ginzburg (1989), cuja essência formata um método focado na análise de detalhes considerados insignificantes, mas capazes de ceder indícios reveladores de uma satisfatória interpretação qualitativa. Assim, torna-se possível inferir possíveis caminhos percorridos para obter os efeitos encontrados na realidade estudada, muitas vezes, inatingível pelo observador.

Considerar todos os vestígios que os ofícios e relatórios nos trazem sob uma perspectiva não só linguística, mas também sócio-histórica amplia a ótica do campo de análise de maneira significativa a ponto de nos permitir visualizar a influência republicana no plano linguístico.

Nosso objetivo será estabelecer uma correlação entre o modelo linguístico adotado pelos grupos escolares e o imaginário republicano. Por serem apontados pela

\footnotetext{
${ }^{16}$ Expressões formulaicas são construções formais que seguem um mesmo modelo de elaboração e se repetem em gêneros textuais também de caráter formal, no caso, os ofícios analisados. Já as expressões abertas são construções diferentes umas das outras e geralmente não se repetem nos textos.
} 
literatura como representantes legítimos da Primeira República e por adquirirem visibilidade ao servir de bandeira para o novo governo, os Grupos Escolares paulistas adotariam a ênclise como padrão linguístico seguindo os intelectuais republicanos que a utilizavam como marcador de diferenças sociais.

Para essa análise, sistematizaremos os dados levantados dos dois tipos de documentos (ofícios e relatórios) em um único conjunto, apenas dividindo-os pelos respectivos Grupos Escolares a fim de esboçar um mapa que apresente a situação de cada escola juntamente com o padrão linguístico adotado. A disposição geográfica dos Grupos Escolares, cujas amostras serão alvo de análise, permitiu uma divisão em quatro regiões: os que se encontram nas cidades do Vale do Paraíba, na cidade de São Paulo, no Oeste Paulista Velho, ou seja, nas cidades que orbitam Campinas, e no Oeste Paulista Novo, o qual engloba as cidades entre Limeira e Ribeirão Preto.

Como os Grupos Escolares foram expandidos pelo estado de São Paulo como símbolo legítimo da Primeira República, tentaremos buscar correlação entre essa expansão e a difusão da norma linguística utilizada pelos republicanos paulistas, tomando como parâmetro de análise a ênclise como marcador social (OLIVEIRA, 2013, 2014a, 2014b).

\section{O final do século XIX: os três modelos de colocação pronominal}

O destaque adquirido pela temática da colocação pronominal no fím da Monarquia e na Primeira República brasileiras motivou a produção de trabalhos que conjugaram, analiticamente, língua e sociedade, tecendo as possíveis relações entre as ocorrências linguísticas e suas motivações externas advindas de vetores sóciohistóricos, políticos e econômicos. 
Em período monárquico, José de Alencar dá início à questão pronominal quando se torna alvo das críticas de José de Castilho publicadas na imprensa, as quais enfatizavam o uso que o escritor faz da ênclise em orações subordinadas e da próclise em construções com verbos no infinitivo precedidos da preposição $a .^{17}$

A discussão se fortalece em 1902 e adquire papel importante - senão fundamental - na crise normativa ${ }^{18}$ do final do século XIX com a polêmica envolvendo a figura de Rui Barbosa. A consciência de qual padrão adotar emerge de fato, pois a querela pronominal é reforçada pelo posicionamento do senador em seu parecer essencialmente linguístico sobre o Código Civil escrito por Clóvis Bevilácqua, no qual a posição dos clíticos recebe amplas críticas. (PAGOTTO, 2012).

Rui Barbosa polemiza suas notificações a tal ponto que a Câmara responde por meio de Carneiro Ribeiro, clássico defensor do culto à norma linguística. A grande repercussão provocada pelo assunto se originou, portanto, da tensão travada entre dois grandes representantes da elite letrada brasileira, o bacharel e o gramático.

Conselheiro defensor do progresso alcançável por meio da modernização do sistema de ensino, Rui Barbosa atuou na reforma dos programas de Língua Portuguesa do Colégio Dom Pedro II, a qual se espelhou nas referências internacionais do tema. Apesar desse perfil modernizador, o senador adota uma postura conservadora na revisão do texto de Clóvis Bevilácqua, e resgata modelos gramaticais buscados no português europeu moderno. (idem).

Um dos contextos destacados no parecer é a próclise em início de sentença principal posposta, ${ }^{19}$ construção que Carneiro Ribeiro defende por ser a mais comum e

\footnotetext{
${ }^{17}$ Apud Chaves de Melo 1972:17-18.

18 A expressão crise normativa é retirada de Pagotto (2012) e faz referência à mudança nos padrões normativos que teve início, de acordo com o autor, a partir dos anos $1850 \mathrm{com}$ a polêmica envolvendo José de Alencar.

${ }^{19} \mathrm{O}$ artigo que motivou a discussão é: Art. 107. Se a simulação for absoluta, sem que tenha havido intenção de prejudicar a terceiros, ou de violar disposição de lei, e for assim provado a requerimento de
} 
por encontrar autoridade nos clássicos. Apesar de reconhecer os usos dos grandes autores, o senador afirma, paralelamente, que não são suficientes para autorizar esse emprego e condena tal ocorrência de acordo com as normas gramaticais que prescrevem o uso da ênclise.

A controvérsia instala-se pelo fato de que Carneiro Ribeiro opera com os usos linguísticos em voga no português brasileiro da época, ao passo que Rui Barbosa assume sua atitude conservadora e recorre, na visão de Pagotto, às normas do português europeu moderno, reprovando a variedade brasileira.

Essa interpretação do português europeu moderno como modelo é contestada por Oliveira (2011), a qual reavalia a questão em um contexto sintático específico. Para isso, investiga comparativamente o estilo dos escritores brasileiros e portugueses.

A análise foca o fenômeno da colocação pronominal em contexto de infinitivas preposicionadas em cartas pessoais escritas ao longo do século XIX dos portugueses Almeida Garrett, Alexandre Herculano, Camilo Castelo Branco, Eça de Queirós e Fernando Pessoa, e dos brasileiros José de Alencar, Álvares de Azevedo, Machado de Assis, Lima Barreto e Mário de Andrade.

A autora constata que, ao longo do século XIX, configurou-se a mudança de uma gramática brasileira enclítica para uma proclítica, já que José de Alencar e Álvares de Azevedo adotam o padrão enclítico, Machado de Assis e Lima Barreto apresentam oscilação e, em Mário de Andrade, prevalece a próclise.

algum dos contraente, se julgará o ato inexistente. (PAGOTTO, 2011). A próclise da oração principal se julgará o ato inexistente, que aparece posposta à oração subordinada condicional, é alvo da controvérsia sobre colocação pronominal. 
Gráfico 1. Ênclise em escritores brasileiros

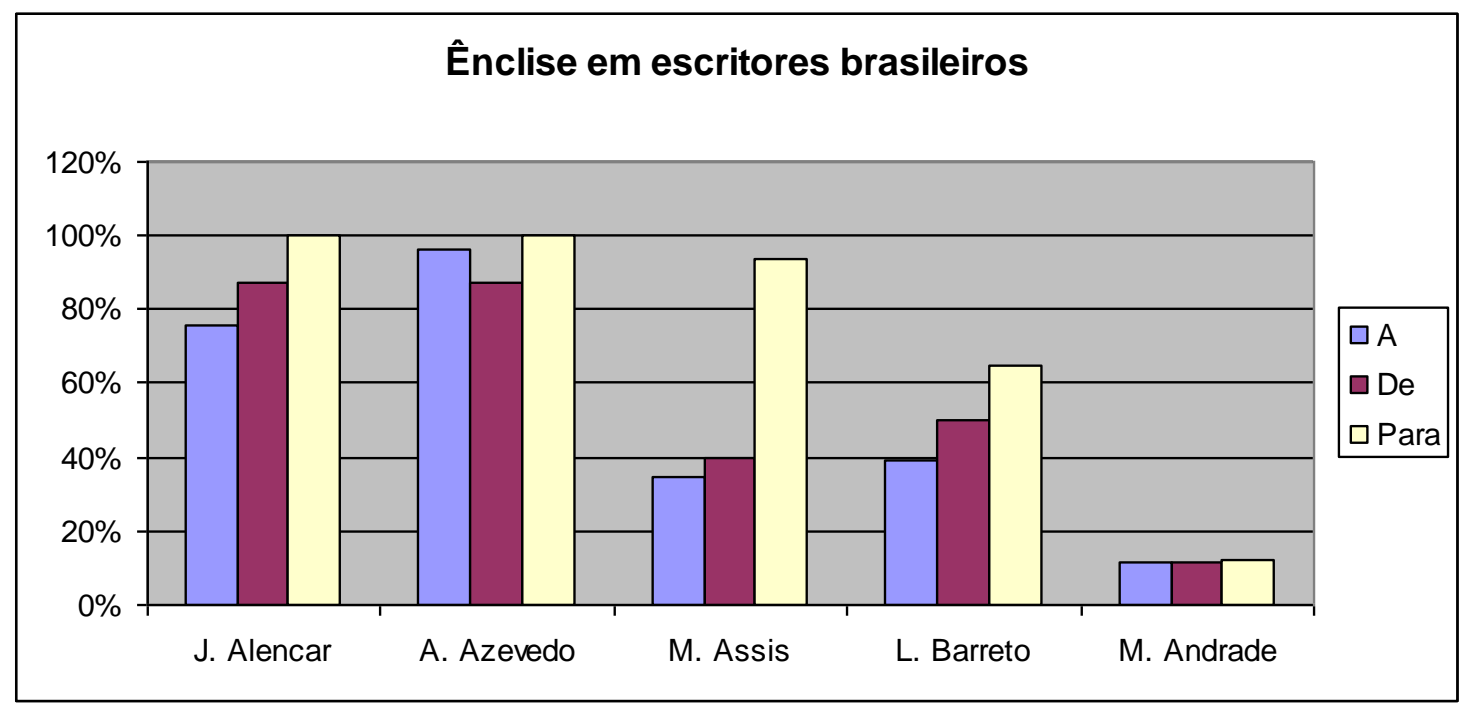

Fonte: Adaptado de Oliveira (2011).

Com relação aos autores portugueses, a ênclise é de uso categórico em presença da preposição $a$ e a próclise é quase categórica com as demais preposições, regra não encontrada nos escritores românticos brasileiros, pois neles todas as preposições funcionam da mesma maneira: ênclise.

Gráfico 2. Ênclise em escritores portugueses oitocentistas

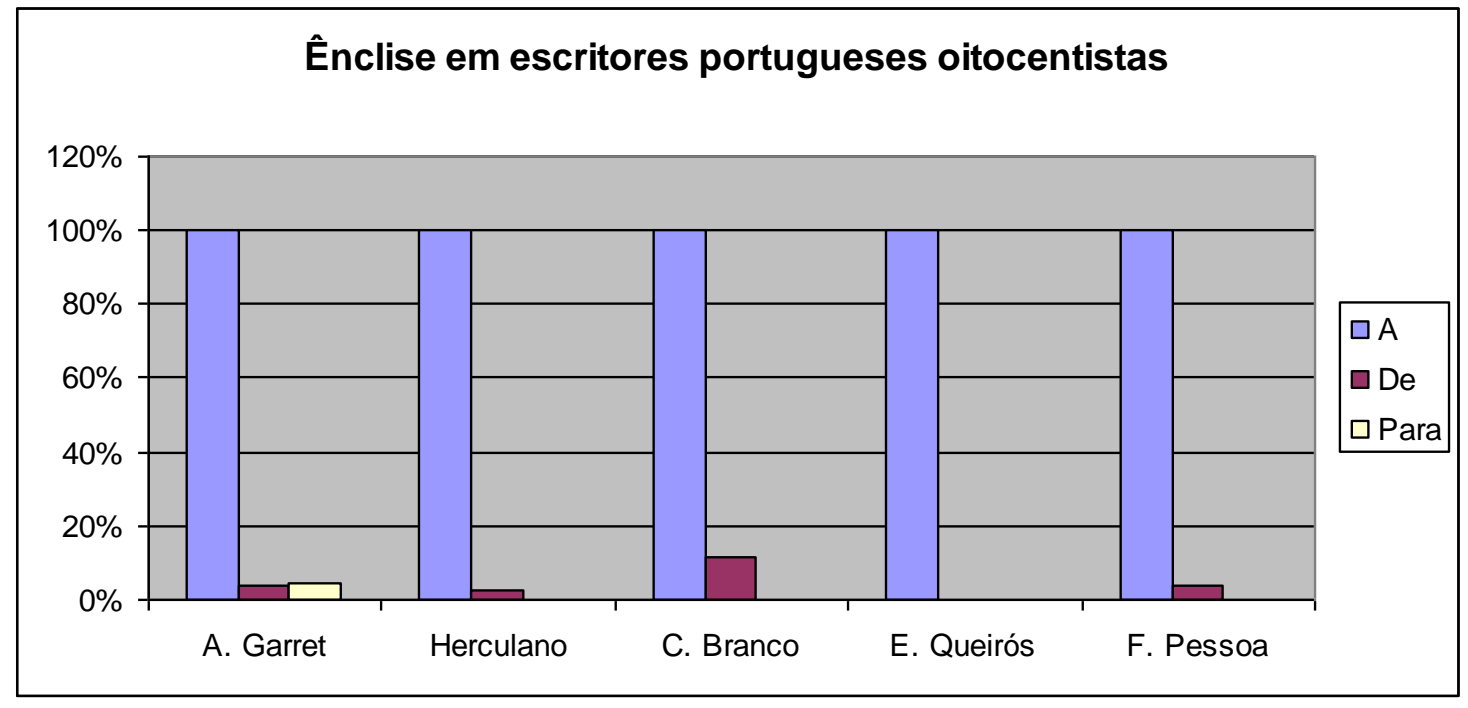

Fonte: Adaptado de Oliveira (2011). 
Em trabalho posterior, Oliveira (2013) revê a hipótese de mudança na colocação pronominal, tendo em vista a formação diferente dos escritores românticos, bacharéis em direito pela Faculdade do Largo de São Francisco, e os demais escritores. Como contraponto, analisa correspondências de circulação pública, produzidas entre os séculos XVIII e início do XX. Essa análise permitiu a identificação da escrita brasileira do século XVIII com o padrão europeu moderno (ênclise em ambiente da preposição $a$ e próclise na presença das demais preposições), diferentemente da escrita do século XIX que se afasta do padrão europeu por favorecer a ênclise em todos os ambientes linguísticos:

Gráfico 3. Ênclise: correspondências de circulação pública escritas no Brasil

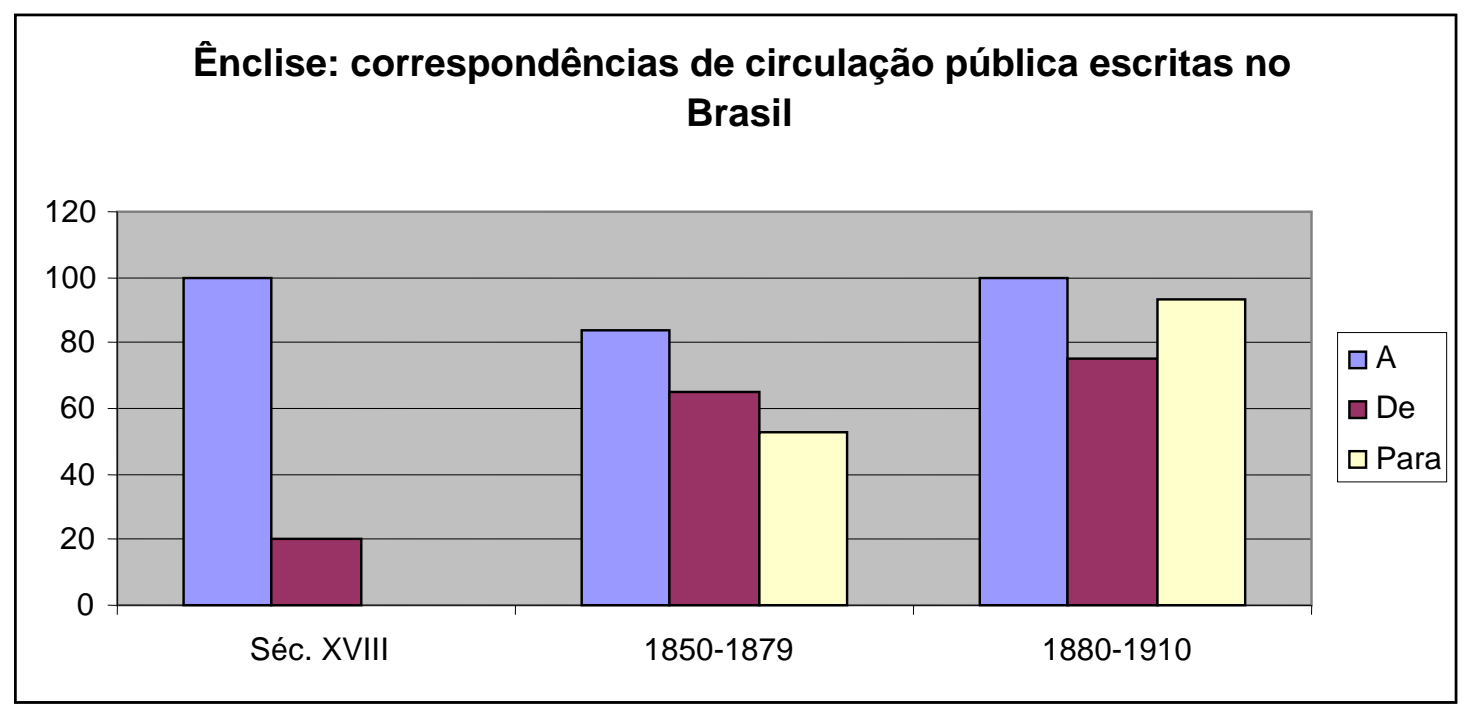

Fonte: Adaptado de Oliveira (2013).

Com efeito, na metade do oitocentos a colocação enclítica extrapola o contexto lusitano da preposição $a$ nos textos da elite político-econômica e ganha forças ao longo do século XIX, distanciando-se do uso proclítico dos literatos em suas cartas pessoais. 
Esses achados sugerem:

1. Literatos e elite político-econômica (autores das correspondências de circulação pública) não compartilham a mesma gramática ao final do século XIX. Aqueles fazem opção pelo vernáculo, ao escolherem a próclise generalizada, e esta, na contramão da variedade falada do português no Brasil cujos traços brasileiros vão se impondo, adota a ênclise generalizada. Esses dados linguísticos reverberam a clivagem da classe intelectual após o movimento da década de 1870. Antes desse período, intelectuais e classe sócio-política formavam uma só categoria; a partir dessa década formam-se categorias distintas. (ALONSO, 2002).

2. Nem literatos nem elite política brasileira adota o padrão europeu de língua portuguesa, em que a ênclise não é regra geral, antes sofre restrições pelo tipo de preposição regente.

As análises da colocação pronominal em discursos de parlamentares formados em Direito pela Faculdade do Largo de São Francisco (OLIVEIRA, 2014a) e de romancistas/cronistas formados na mesma faculdade, como Monteiro Lobato, Godofredo Rangel e Moacir Piza - identificados como escritores calígrafos por Antônio Cândido ${ }^{20}$ pelo rebuscamento linguístico - sugerem a ênclise como marcador social dos bacharéis. (OLIVEIRA, 2014b). A esse propósito, vale lembrar que os cargos políticos eram essencialmente ocupados pelos bacharéis em direito no final do século XIX (CARVALHO, 2012), o que justifica o emprego de formas linguísticas distintivas.

O mesmo período é abordado por Santos Silva (2012) no contexto específico da formação da cidade de São Paulo, palco de atuação dos intelectuais republicanos paulistas, cujas produções linguísticas são analisadas sob o ponto de vista sóciohistórico. O uso linguístico dessa classe pressupunha o português culto paulista, pois se

20 "Literatura Caligráfica", introdução à edição de Falange gloriosa, de Godofredo Rangel. São Paulo: Melhoramentos, s/d. 
tratava de uma elite detentora de poder político e econômico, quadro que motivou a análise dessa variedade vinculada ao seu valor social.

Tomando como objeto a ordenação dos clíticos pronominais, dentre outros contextos, em infinitivas preposicionadas, a autora constata que esse modelo se difere tanto do vernáculo como do português europeu moderno, o que resulta na apropriação das ocorrências linguísticas dessa elite como marcadoras de expressivas diferenças entre os falantes das diversas classes sociais da cidade de São Paulo na virada do século XIX.

Baseada na verificação do uso da ênclise em escritores românticos que passam pela Academia de Direito (OLIVEIRA, 2011), Santos Silva verificou textos produzidos na virada do século XIX bacharéis formados por esse espaço de convivência intelectual e política que exercia forte influência, inclusive linguística, em outros espaços sociais, como por exemplo, as Câmaras e a Escola Normal de São Paulo.

Prudente de Moraes, Campos Sales, Alberto Sales, Rodrigues Alves e Júlio de Mesquita tiveram seus discursos políticos, mensagens, cartas pessoais, cartas públicas, bilhetes, estudos científicos, artigos públicos em livros e jornais (SANTOS SILVA, op. cit., p. 76) analisados na pesquisa. A ênclise categórica detectada na escrita desses intelectuais em determinados contextos não segue o padrão de colocação pronominal lusitano, pois em orações com verbos infinitivos preposicionados por de e para, contexto em que seria previsível o padrão proclítico, seja no português europeu, seja no vernáculo brasileiro, encontra-se privilegiada a posição enclítica do pronome: 
Gráfico 4. Ênclise em textos de intelectuais republicanos paulistas

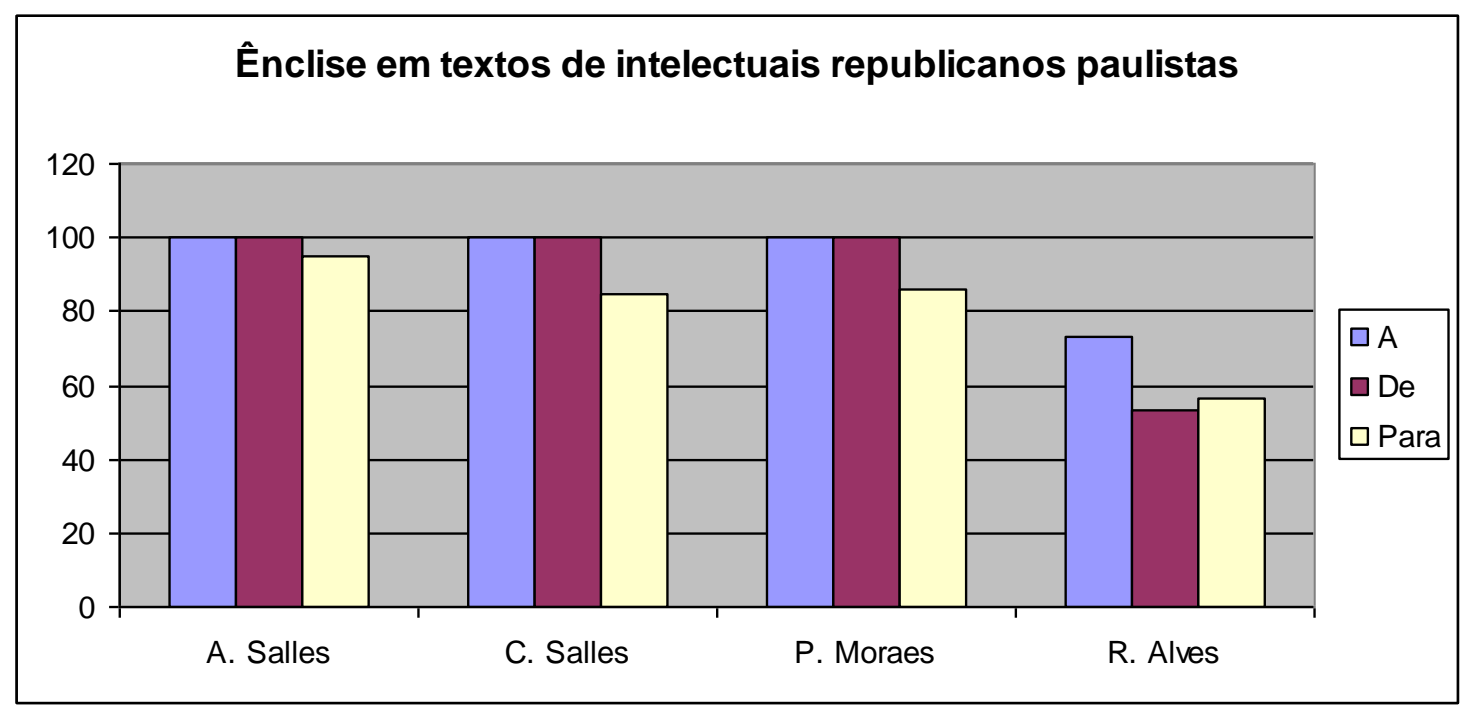

Fonte: Adaptado de Santos Silva (2012).

A autora evidencia, portanto, uma gramática enclítica na produção dos intelectuais republicanos paulistas configurada não apenas pelo grau de instrução dos informantes com relação aos falantes de outras classes sociais, principalmente, os não escolarizados, mas também o distanciamento da norma portuguesa. Assim, o processo enclítico, paralelamente a outros condicionantes culturais, opera como marcador social.

A partir desse panorama, consideramos, então, a existência de três modelos operantes no final do século XIX: o português (ênclise na presença da preposição $a$ e próclise com as demais preposições), o vernáculo brasileiro (crescimento da posição proclítica) e o que atua em contexto, predominantemente, enclítico, marca da elite bacharelesca (OLIVEIRA, 2014b). Tendo em vista que os intelectuais republicanos paulistas extrapolam o uso da ênclise, tomamos por hipótese que a gramática da ênclise passa a ser posta como norma linguística a ser adotada nos grupos escolares. 


\section{Os ramais da norma}

As amostras linguísticas foram retiradas de ofícios e relatórios provenientes de 36 Grupos Escolares espalhados pelas regiões do Vale do Paraíba, Oeste Paulista Velho e Oeste Paulista Novo. As ocorrências de colocação pronominal encontradas em infinitivas preposicionadas permitem uma análise a partir de diferentes perspectivas, tanto linguísticas como extralinguísticas.

\subsection{Preposições e pronomes: panorama geral}

Como fundamental abordagem linguística, os primeiros critérios adotados foram o tipo de preposição e o tipo de pronome, por meio dos quais obtivemos um panorama geral dos dados coletados capaz de apresentar um ponto inicial a ser observado. Foi possível verificar que o índice referente à colocação pronominal, analisada sob a ótica da preposição, evidencia um elevado uso da ênclise no contexto pesquisado com todas as preposições, cujos percentuais enclíticos ultrapassam os $60 \%$, seguindo o padrão encontrado em SANTOS SILVA (2012) e Oliveira (2013, 2014a e 2014b): 
Gráfico 5. Colocação pronominal por tipo de preposição ${ }^{21}$

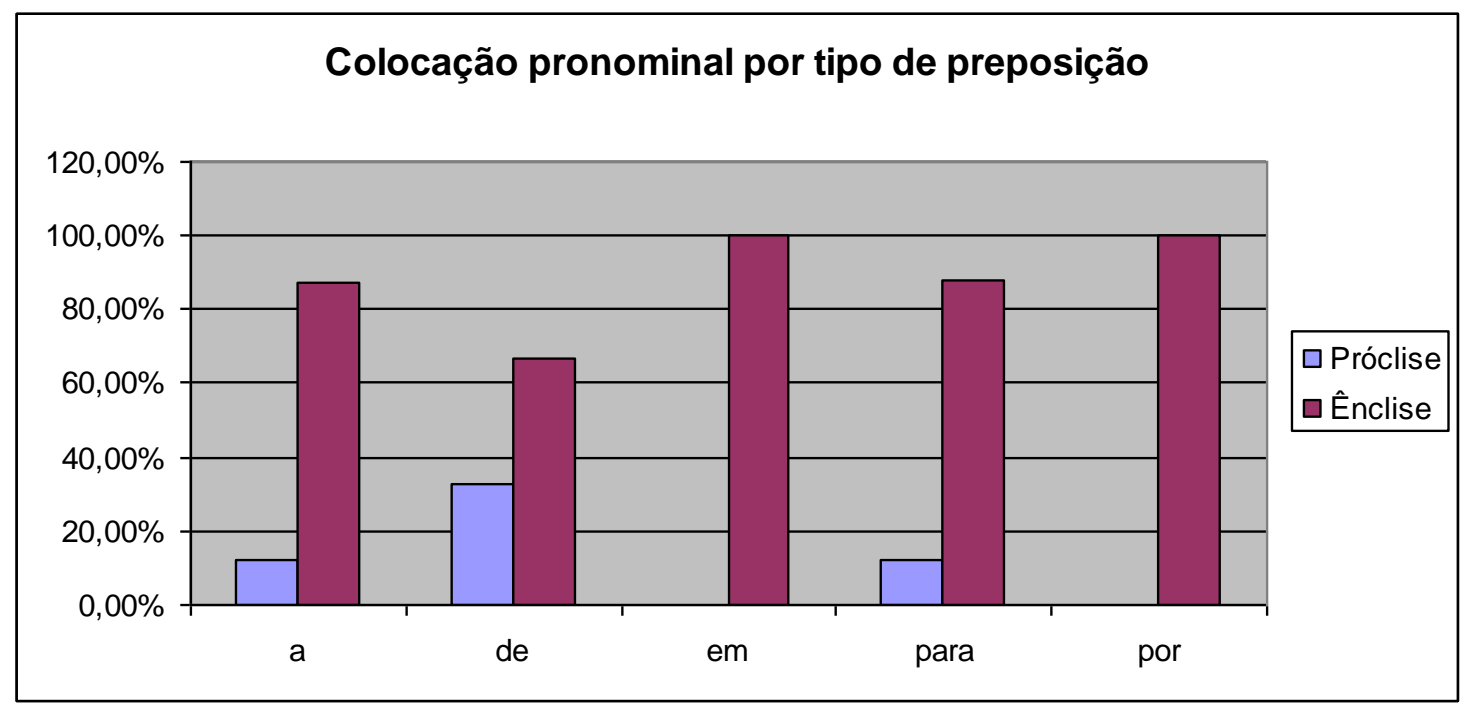

Ao verificar o tipo de pronome dessas ocorrências, constatamos que a ênclise prevalece, de forma equiparada, com todos os pronomes e carrega consigo percentuais também acima dos 60\%:

Gráfico 6. Colocação pronominal por tipo de pronome ${ }^{22}$

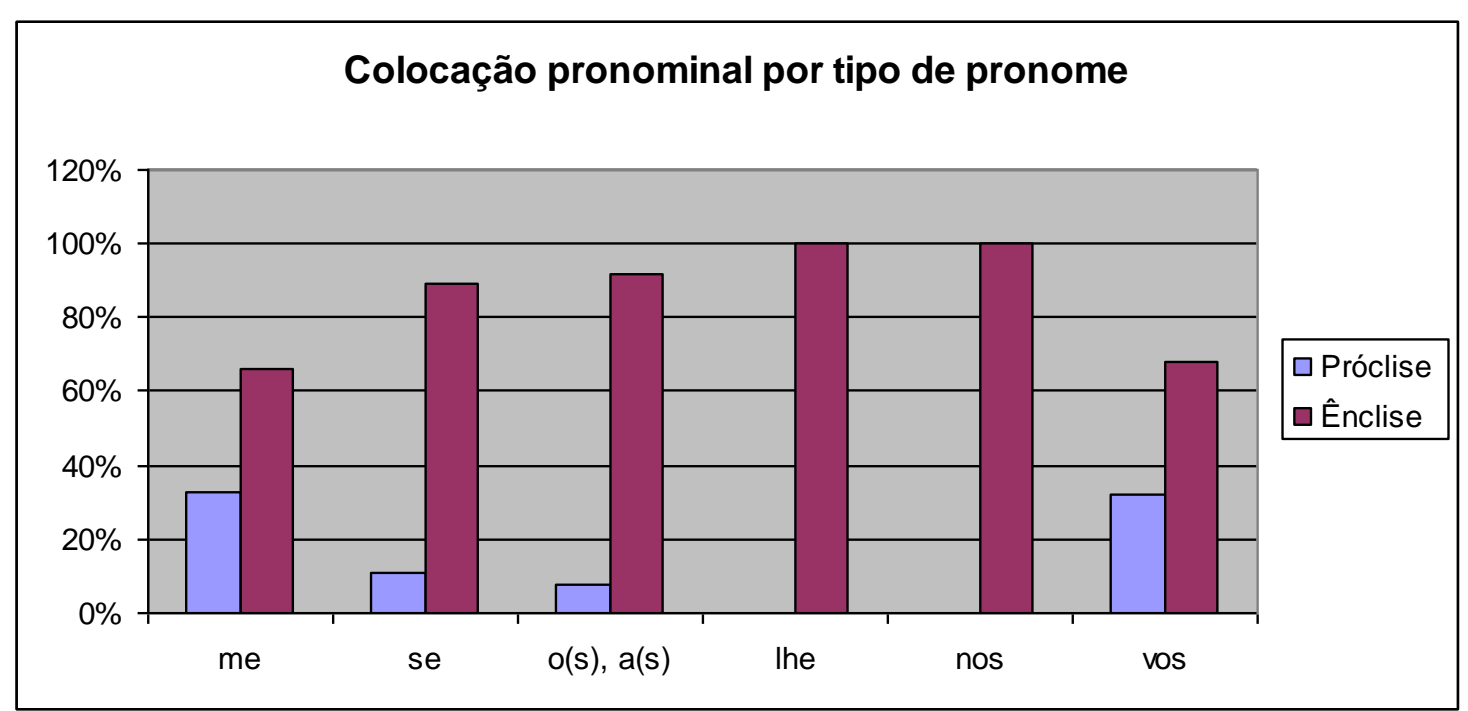

${ }^{21}$ Dados expostos na Tabela 2 dos anexos.

${ }^{22}$ Dados expostos na Tabela 3 dos anexos. 
Mediante os resultados acima expostos, averiguamos que, mesmo a posição enclítica se sobressaindo em ambos os casos, o tipo de preposição e o tipo de pronome não se tornam fatores linguísticos incidentes na colocação pronominal, pois não chegam a regular o uso e sim o generalizam. Dessa forma, a ênclise deixa de estar condicionada e passar a ser potencializada.

\subsection{Expressões formulaicas e expressões abertas}

As amostras permitiram outro tipo de abordagem, que se tornou um critério adicionado à análise linguística, e se pauta na divisão dos dados em dois grupos. Um deles é composto por expressões formulaicas, as quais, por serem formas que seguem um mesmo modelo formal de elaboração e se repetem nos documentos em questão, teoricamente, não comportariam variação. Comparece-se o exemplo 1, retirado de ofício, e os exemplos 2 e 3. extraídos de relatórios:

(1) Tenho a honra de enviar-vos inclusamente os mappas do movimento deste Grupo Escolar, durante o mez de Dezembro, findo, que foi de férias. (Grupo Escolar Cel Flaminio Ferreira - Limeira, 1901).

(2) São estes os factos ocorridos durante o anno lectivo findo, os geraes em largos traços e com a devida consideração e respeito tenho a subida honra de vos relatar. (Grupo Escolar Dr. Jorge Escolar Tibiriçá - Bragança Paulista, 1906).

(3) Em cumprimento do disposto no artg. $59 \S 9$ do Regulamento da Instrucção Publica de 11 de janeiro de 1898, tenho a subida honra de apresentar-vos o meu 
relatorio juntamente os mappas e quadros explicativos sobre o movimento do $1^{\circ}$ Grupo Escolar de Campinas durante o anno lectivo de 1906. (1 ${ }^{\circ}$ Grupo Escolar de Campinas, 1906).

A colocação pronominal nos exemplos acima poderia ser justificada pela diferença de destinatário, no entanto, todos os documentos são encaminhados para a mesma autoridade superior hierarquicamente. Por esse motivo, esse fator é irrelevante e não será considerado.

O outro grupo de expressões é o que engloba construções que não seguem um modelo específico de formação, além de não serem encontradas, repetitivamente, no restante do corpus. Pela característica de livre elaboração, denominaremos esse conjunto de expressões abertas:

(4) Até uns 20 alumnos comportavão, perfeitamente, nestas salas, precisando, apenas de se construir $26 \mathrm{~m}^{2}$ de quadros negros, conforme pedido reiterado e constante de meu officio $n^{\circ} 8$, de 7 do corrente, que ainda uma vez peço licença para reiterar. (Grupo Escolar Cel Siqueira Moraes - Jundiaí, 1902).

(5) Este número tende a elevar-se a 300, talvez, pois que a Camara Municipal decretou o ensino obrigatório, sob pena de pesada multa. (Grupo Escolar Cel. Augusto Cezar - Leme, 1902).

(6) Todos esses professores desistiram das mesmas licenças muito antes de approximar-se o praso pelo seu retorno. (Grupo Escolar de Piracicaba, 1906). 
Como ambos os casos de colocação pronominal, próclise e ênclise, foram encontrados nos dois grupos de expressões apresentados, não há relevância em se considerar esses conjuntos separadamente. Por esse motivo, agora elas serão consideradas em bloco.

\subsection{A abordagem geográfica}

A atuação linguística de colocação pronominal em infinitivas preposicionadas se difere entre os Grupos Escolares paulistas selecionados para esta pesquisa. Com o levantamento dos dados, conseguimos identificar quatro modelos em uso: o modelo português, que se caracteriza pela próclise com a preposição a ênclise com as outras preposições; o modelo brasileiro, pautado pela próclise generalizada; a ênclise categórica e um sistema variante entre os dois tipos de colocação.

\subsubsection{Modelo português: ênclise apenas com a preposição $a$}

Sob uma perspectiva geográfica, um mapeamento dos Grupos Escolares paulistas com seus respectivos padrões linguísticos adotados mostra que os grupos de Itu e Tatuí apresentam casos de colocação pronominal em infinitivas preposicionadas em consonância com o modelo português, pois encontramos ênclise categórica com verbos regidos pela preposição $a$ e próclise com as demais preposições:

(7) Assim pensando, tenho a declarar-vos que neste anno, como nos anteriores, todos os professores são dignos de elogios no exercicio do cargo pelo esforço 
desenvolvido e pela observancia as disposições legaes. (Grupo Escolar Dr. Cesario Motta - Itu, 1906).

(8) O desenho, a fazer-se diretamente do natural, tornou-se difficil por não o terem aprendido assim os professores. (Grupo Escolar de Tatuí, 1906).

(9) Nesses dias foi extraordinaria a concorrencia do povo ytuano, podendo affirmar que não houve uma familia que deixasse de se representar nessas festas. (Grupo Escolar Dr. Cesario Motta - Itu, 1906).

$(10)$ O material foi sufficiente para o trabalho escolar, com falta apenas de um armario para cada sala, o que obrigou a depositar-se no chão a papelada em uso nas differentes salas, conforme tive occasião de vos fazer sentir por mais de uma vez. (Grupo Escolar de Tatuí, 1906).

A colocação pronominal apresentada por Itu e Tatuí evidencia a adoção do modelo português, o que sugere a possibilidade da origem dos diretores desses grupos, portanto, provavelmente ser portuguesa. ${ }^{23}$

\subsubsection{Generalização da ênclise}

Já os Grupos Escolares de Avaré, Guaratinguetá, Jaboticabal, Leme, Limeira, Lorena, Mogi Mirim, Piracicaba, Ribeirão Preto, São Paulo, São Roque, São Simão e Taubaté apresentam os clíticos posicionados, categoricamente, em posição enclítica,

\footnotetext{
${ }^{23}$ Infelizmente, não conseguimos recuperar a origem dos diretores dos grupos de Itu e Tatuí para comprovar a hipótese. Linguisticamente, porém, os dados sugerem que esses diretores tivessem recebido input da gramática lusitana.
} 
fato que corrobora com os resultados de ênclise generalizada, independentemente, do tipo de preposição e de pronome:

(11) Embora o $\mathrm{Art}^{\mathrm{o}}$ 63§Único do Reg. De 11 de $\mathrm{Jan}^{\circ}$ de 1898, não autorize esta creação, visto como esta nova professora deverá reger uma classe 15 alumnas apenas, entende esta directoria ser caso de excepção, por tratar-se de conveniencia para o ensino, na separação destas duas classes. (Grupo Escolar Gabriel Prestes - Lorena, 1902). Continuando apezar disso, a syndicancia exigida pelo caso, verifiquei por essa forma que o menino filho do cidadão Eduardo Sughi, era de facto um insubordinado ao qual já havia por diversas vezes ameaçado de expulsal-o, deste estabelecimento de ensino, caso não se corregisse. (Grupo Escolar de Ribeirão Preto, 1906).

$$
\text { Isto nos basta, para justificar-nos perante nossa consciencia _ juiz }
$$
supremo das nossas acções, e tambem perante os nossos superiores hierarchicos, aos quaes não deviamos omittir esta occurrencia, neste relatorio; o que pode ser de algum alcance para evitar futuras contrariedades. (Grupo Escolar de São Simão, 1906).

(14) Passo agora a dar-vos o quadro do corpo de alumnos e a delles fazer-vos o historico (Annexos nº 2 e 3). (Grupo Escolar Dr. Moraes Barros - Piracicaba, 1902). 
Esses dados mostram que tanto a região do Vale do Paraíba quanto a do Oeste Paulista fazem uso generalizado da ênclise. Não se pode associá-la, portanto, à oposição entre fazendeiros do Vale para o Oeste.

\subsubsection{Generalização da próclise}

Dentre todos os Grupos Escolares do estado de São Paulo pesquisados, apenas dois deles, o de Itapira e Serra Negra, se configuram como contextos categoricamente proclíticos, característica da variedade vernacular do português brasileiro:

Tenho a honra de vos indicar o nome da professora preliminar $\mathrm{D}$

Augusta de Toledo para preencher a vaga aberta neste Grupo com a nomeação

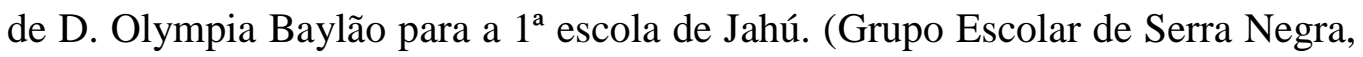
1901).

(16) Retirou-se no dia 27 de Maio que, satisfeito com o resultado da sua visita cujo termo, escripturado ao livro competente, tomo a liberdade de o transcrever abaixo (...) (Grupo Escolar Dr. Júlio de Mesquita - Itapira, 1902).

Tenho a honra de vos enviar o incluso relatorio do movimento deste grupo relativo ao anno lectivo de 1901 e bem assim o mappa do ultimo smestre. (Grupo Escolar Dr. Júlio de Mesquita - Itapira, 1902).

A preferência pelo padrão vernacular selecionadora da próclise como colocação pronominal pode ser justificada pela disposição geográfica dessas cidades como se 
observa no mapa abaixo que delineia a disposição da malha das estradas de ferro da época:

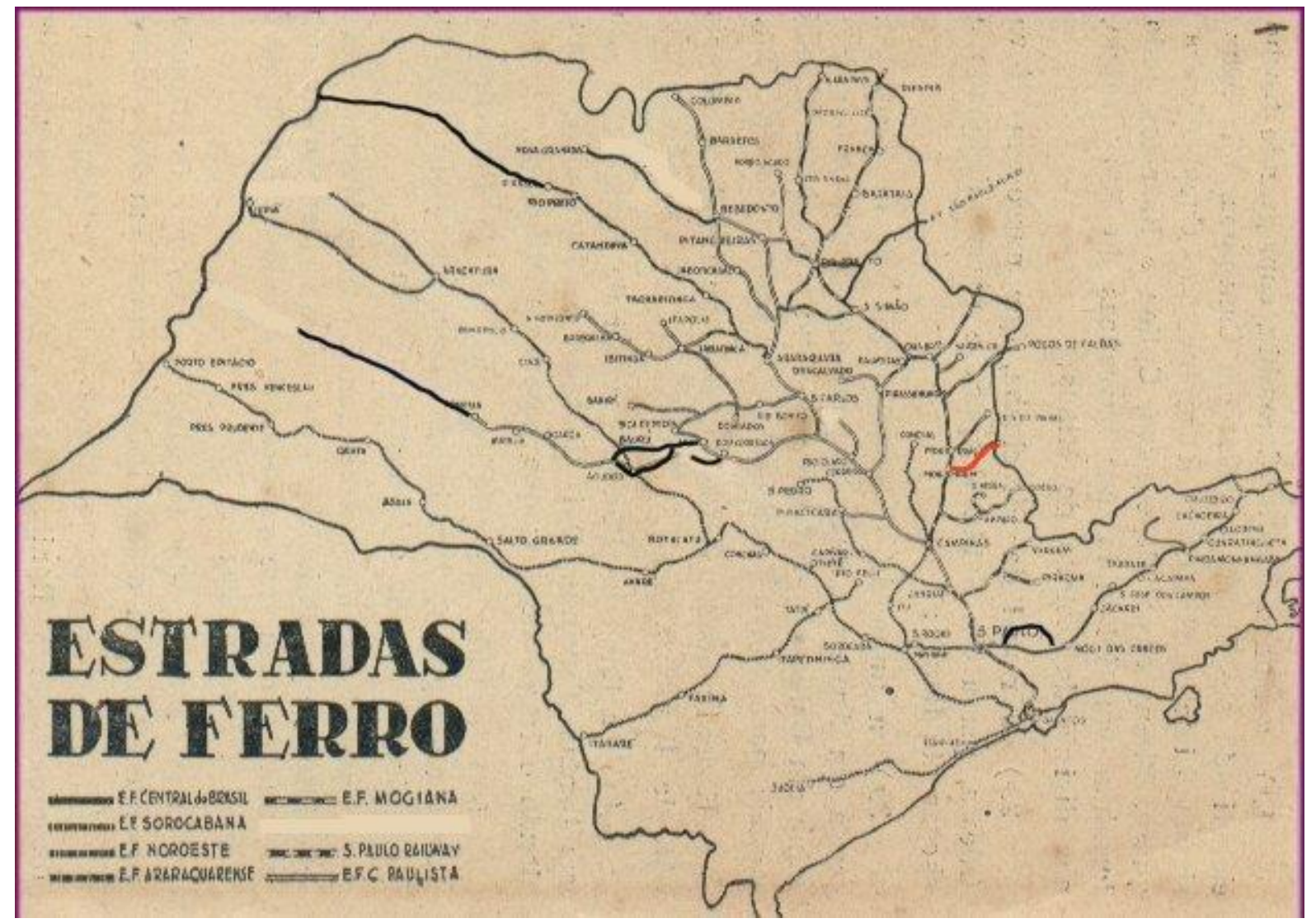

Tanto Itapira quanto Serra Negra se encontram nas extremidades dos ramais ferroviários, ou seja, estão fora das rotas principais que ligam a cidade de São Paulo ao interior. Além disso, essas cidades se distribuem ao longo de linhas ferroviárias que penetram no território mineiro que, por hipótese, não compartilha a função social da ênclise nos moldes verificados para os intelectuais republicanos paulistas.

\subsubsection{A variação em pauta}

Alguns grupos, como o de Bragança Paulista, Campinas, Espírito Santo do Pinhal, Mococa, Jundiaí, São José dos Campos, São Luiz do Paraitinga e São Manoel 
do Paraíso, evidenciam pronomes ocupando posição proclítica e enclítica com verbos regidos pelas diversas preposições, seja em expressão formulaica ou aberta, não elucidando o seguimento de uma regra determinada:

$$
\text { Cumprindo o disposto no art. }{ }^{\circ} 59 \S 17 \text { do Regulamento de } 11 \text { de janeiro }
$$

de 1898, tenho a honra de vos remetter a folha de pagamento do pessoa deste grupo, correspondente ao mez de Janeiro proximo findo. (Grupo Escolar Dr. Almeida Vergueiro - Espírito Santo do Pinhal, 1902). Aproveito o ensejo para communicar-vos que, de conformidade com o vosso telegramma de 3 do fluento, assumi hontem como professora mais antiga, a direcção interina deste grupo. (Grupo Escolar Dr. Almeida Vergueiro Espírito Santo do Pinhal, 1902).

(20) Nada mais tendo a vos expor com relação ao $1^{\circ}$ Grupo Escolar de Campinas, cuja marcha tem sido regular, aqui termino o presente relatório. $\left(1^{\circ}\right.$ Grupo Escolar de Campinas, 1906).

(21) Assim, pois, tenho a honra de propor-vos para adjunctas deste grupo, em preenchimento ás nossas vagas, as professoras complementaristas D.D. Virginia Van Haute e Amélia Athayde de Andrade, de cujos diplomas junctos publico. (Grupo Escolar Cel Siqueira Moraes - Jundiaí, 1902).

As ocorrências linguísticas do sistema em variação denotam que não há uma regra específica que regule a próclise ou a ênclise nesse contexto. Porém, apesar de 
variantes, evidenciamos que a próclise predomina nos Grupos Escolares de Campinas e Mococa, e a ênclise exerce soberania nos demais, Bragança Paulista, Espírito Santo do Pinhal, Jundiaí, São José dos Campos, São Luiz do Paraitinga e São Manoel do Paraíso.

Assim, mapeando os Grupos Escolares com seus respectivos padrões linguísticos adotados, levando em consideração o predomínio de um modelo nos casos dos grupos que explicitam variação, podemos apontar, com clareza, a hegemonia da ênclise pelo território paulista no começo do século XX, como se vê no mapa abaixo:

Mapa 2. Padrão linguístico dos Grupos Escolares Paulistas

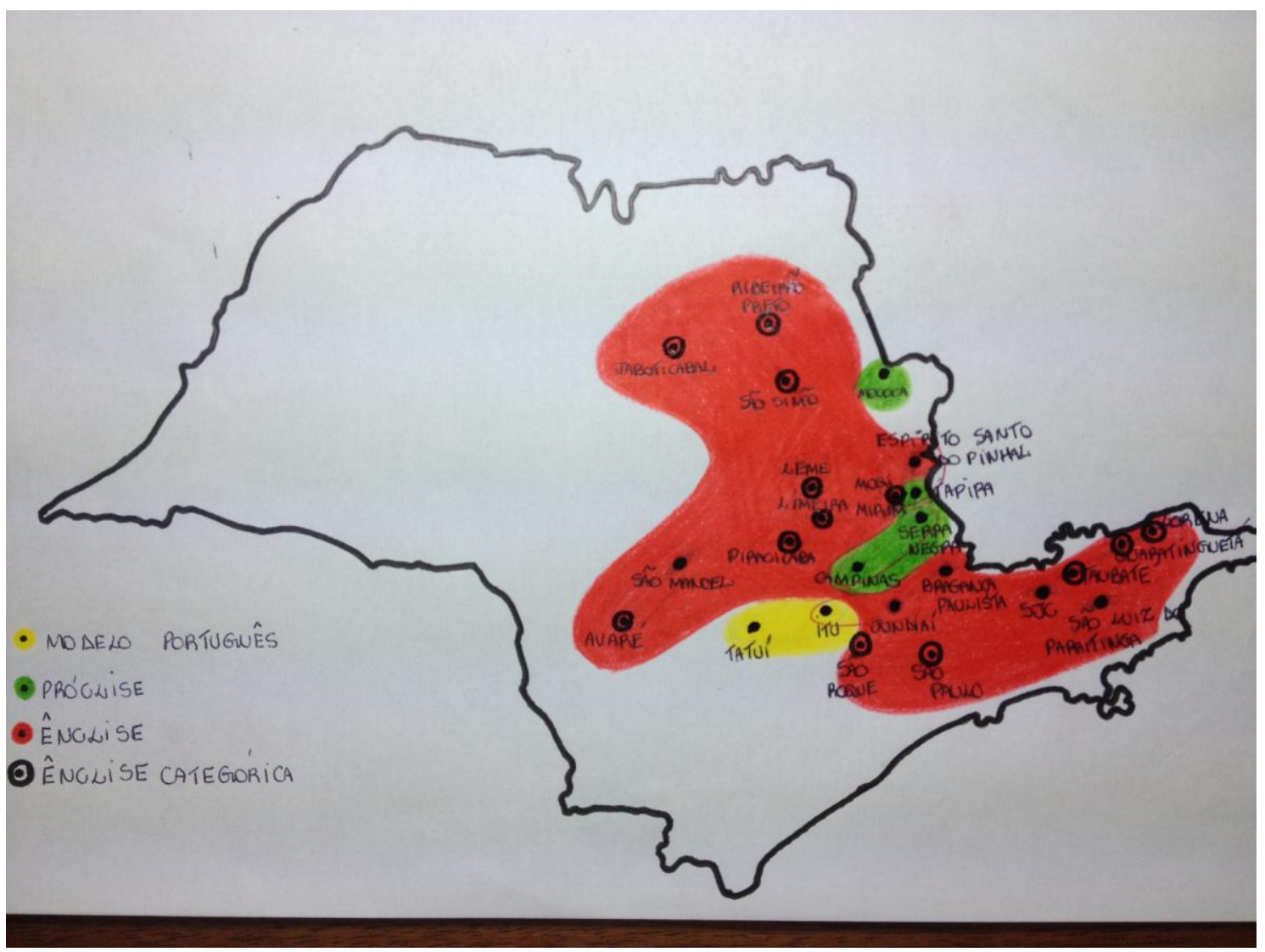

Duas ilhas se formam no espaço de extensão da ênclise. Paradoxalmente, essas duas ilhas são o núcleo da formação do partido republicano. No caso da ilha em amarelo, Itu e Tatuí, o sistema em operação é o português e a única hipótese plausível é 
a origem portuguesa dos autores dos textos. A variação encontrada em Campinas também se contrapõe à forte presença de republicanos nessa cidade. É possível que o êxodo populacional, em virtude da epidemia de febre amarela em 1889, esteja na base do realinhamento linguístico com Serra Negra e Itapira, que adotavam a próclise.

\subsubsection{Abordagem linguística: tipo de verbo}

Atentando-se às pistas que poderiam nos levar um pouco além do simplório não seguimento de uma regra determinada, observamos o interessante comportamento dos Grupos Escolares de Mococa e São José dos Campos, os quais operam de forma contrária quanto a um outro critério analisado, o tipo de verbo operante na colocação pronominal.

Uma diferença se estabelece entre verbos que representam apenas o cumprimento da função profissional do diretor, os que informam e enviam informações sobre o funcionamento dos grupos e os que extrapolam essas atividades, indicando e propondo algo a seus superiores.

O tipo de verbo, então, se mostra fator relevante de análise apenas em relação aos Grupos Escolares de Mococa e São José dos Campos, como verificamos nos seguintes exemplos que apresentam, todos eles, a estrutura tenho a honra de:

$\underline{\text { Tenho a honra de vos enviar }}$ o incluso mappa das faltas de comparecimento dos professores e empregados do Grupo Escholar desta cidade, no mez de janeiro ultimo, contendo no verso o quadro demonstrativo dos vencimentos de cada funccionario ou empregado. (Grupo Escolar de Mococa, 1902). 
Sendo de necessidade urgente o preenchimento desta vaga, tenho a honra

de propôr-vos para ella o professor Belmiro Martins, diplomada pela Eschola de Itapetininga, e espero que vos dignareis attender a esta proposta, com a urgencia que o caso reclama. (Grupo Escolar de Mococa, 1902).

No caso do ofício que comunica a remessa do relatório (22), uma tarefa a ser realizada, o diretor do grupo de Mococa usa a próclise; já naquele em que a atuação do diretor extrapola a burocracia (23), ao designar o nome do professor a ser contratado, o diretor usa a ênclise. O diferencial poderia assim estar na extrapolação da burocracia. Uma outra chave de leitura está na expressão com a urgência que o caso reclama, uma crítica à morosidade no atendimento de propostas. Nesse sentido, a ênclise viria como uma marca de comando, de urgência. Diferente é o emprego da colocação pronominal no material do grupo de São José dos Campos:

Em observância ao que estabelece o paragrapho 17 do artigo 59 do Regulamento de 11 de janeiro de 1898, tenho a honra de remetter-vos um exemplar da folha de pagamento do pessoal deste Grupo, correspondente ao mez de Dezembro findo. (Grupo Escholar de São José dos Campos, 1902).

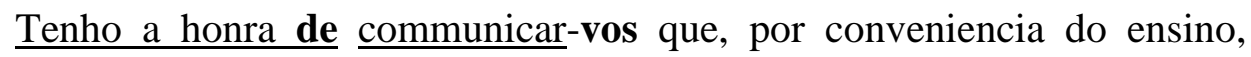
nesta data, entrou em exercicio do cargo de professora substituta a Sra. D. Benedicta Bueno, por mim indicada em data de 4 do corrente a esse secretariado. (Grupo Escolar de São José dos Campos, 1902). 
a Senhora D. Benedicta Bueno. (Grupo Escolar São José dos Campos, 1902).

O ofício que comunica a remessa da folha de pagamento de pessoal (24) e o que informa a respeito do exercício do cargo (25) trazem o emprego da ênclise, ao passo que aquele que trata da designação do nome da professora (26) adota a próclise.

Como se vê, a regra não é a mesma para os dois grupos em questão. O grupo de Mococa usa próclise com verbos comunicativos e ênclise com os propositivos; já o de São José inverte os usos.

Tabela 3. Funções verbais das ocorrências linguísticas dos Grupos Escolares de Mococa e São José dos Campos

\begin{tabular}{|c|c|c|c|c|}
\hline \multirow{2}{*}{} & \multicolumn{2}{|c|}{ Verbos comunicativos } & \multicolumn{2}{c|}{ Verbos propositivos } \\
\hline Mococa & Próclise & Ênclise & Próclise & Énclise \\
& de vos enviar & & & de propor-vos \\
& burocracia/ & & & crítica \\
& cumprimento de & & \\
\hline SJC & protocolo & de remetter-vos & de vos indicar & \\
& & burocracia/ & vênia/ pedido de & \\
& & cumprimento de & licença & \\
& & protocolo & & \\
& & & & \\
\end{tabular}

A referência às atividades cotidianas dos Grupos Escolares expressa pelos verbos comunicativos carrega consigo uma carga valorativa estritamente burocrática, 
representando o cumprimento de um protocolo imposto às escolas. A diferença nos usos se justifica pela avaliação da tarefa realizada. Em Mococa o emprego da próclise assinala uma conotação corriqueira (22); em São José o emprego da ênclise funciona como uma forma de reverência de que lança mão o diretor para atingir, respeitosamente, um superior (24 e 25). Seria, em outras palavras, um bater continência, cuja simbologia assinalaria a disposição ou formação de um corpo de tropas.

O encaminhamento de propostas a uma figura acima do diretor em hierarquia de funções é expresso nos documentos de São José pela próclise (26), cuja simbologia assinalaria - por ser essa colocação tipicamente vernacular - um pedido de vênia, uma licença para sugerir o que se deseja, pois a proposição viria de um subalterno (quase um vassalo). O diretor do grupo de Mococa, que, por sua vez, tece uma crítica velada à demora ao atendimento de sugestões, faz uso da ênclise (23) nesse mesmo ambiente. Nesse caso, a ênclise, tal como a voz de comando sentido!, simbolizaria o alerta e a prontidão no acatamento da proposta.

No caso dos dois atos percolutóricos (comunicar e propor), os diretores atribuem à ênclise instruções dos exercícios militares. A diferença está em que na cidade do Vale do Paraíba a ênclise é uma saudação, um bater continência e, por isso, ocorre no contexto de verbos comunicativos; na cidade do Oeste Paulista a ênclise é um comando no cumprimento da proposta.

Se os Grupos Escolares foram eleitos como meio propagandístico do governo republicano, Mococa manifestava seu comprometimento com as propostas republicanas por meio de ordenação/comando e São José dos Campos se valia do rito cerimonioso da saudação. Não importa, fosse com propostas, fosse com relatos, cada um, a sua maneira, teria que colaborar para que essa simbologia fosse mantida e enraizada nas tradições populares. 


\section{Considerações finais}

Como dito no início desse capítulo, o movimento de implantação dos grupos seguiu o sentido de ocupação do território paulista, iniciando na porção do Vale do Paraíba até a região do Oeste Paulista Velho e seguindo em direção ao Oeste Paulista Novo. Como essas instituições de ensino privilegiaram a adoção da ênclise majoritária, é possível dizer que, à expansão dos grupos, correlaciona-se a difusão do modelo linguístico.

Dentro do ideário sócio-político republicano, ao assumir posturas linguísticas bastante representativas de um jogo de interesses no pano de fundo dos trâmites governamentais da época, dois Grupos Escolares atribuem diferentes funções à colocação enclítica do pronome.

A ênclise usada nos ofícios do grupo de São José dos Campos tem um tom cerimonioso por restringir-se ao ato perlocutório das comunicações oficiais que caracterizam toda a logística de um discurso republicano pautado na exaltação dos grupos e nos exercícios militares, de tal modo que a colocação pronominal enclítica passa a sinalizar a reverência normalmente usada na formação e na saudação das tropas. Já a ênclise no ato perlocutório das proposições realizadas pelo grupo de Mococa reverbera a voz de comando em atitude de alerta e prontidão dos exercícios militares.

A função social da ênclise, nesse contexto, é resultante da adoção dessa colocação como características dos intelectuais paulistas no poder executivo do regime republicano, a qual operava, paralelamente, a outros condicionantes sócio-culturais e políticos, como marcador linguístico que diferenciava o usuário de outras classes sociais - analfabetos - e distanciava do padrão português. 
A referência às atividades cotidianas dos Grupos Escolares expressa pelos verbos comunicativos carrega consigo uma carga valorativa estritamente burocrática, representando o cumprimento de um protocolo imposto às escolas. A diferença nos usos se justifica pela avaliação da tarefa realizada. Em Mococa o emprego da próclise assinala uma conotação corriqueira (22); em São José o emprego da ênclise funciona como uma forma de reverência de que lança mão o diretor para atingir, respeitosamente, um superior (24 e 25). Seria, em outras palavras, um bater continência, cuja simbologia assinalaria a disposição ou formação de um corpo de tropas.

O encaminhamento de propostas a uma figura acima do diretor em hierarquia de funções é expresso nos documentos de São José pela próclise (26), cuja simbologia assinalaria - por ser essa colocação tipicamente vernacular - um pedido de vênia, uma licença para sugerir o que se deseja, pois a proposição viria de um subalterno (quase um vassalo). O diretor do grupo de Mococa, que, por sua vez, tece uma crítica velada à demora ao atendimento de sugestões, faz uso da ênclise (23) nesse mesmo ambiente. Nesse caso, a ênclise, tal como a voz de comando sentido!, simbolizaria o alerta e a prontidão no acatamento da proposta.

No caso dos dois atos percolutóricos (comunicar e propor), os diretores atribuem à ênclise instruções dos exercícios militares. A diferença está em que na cidade do Vale do Paraíba a ênclise é uma saudação, um bater continência e, por isso, ocorre no contexto de verbos comunicativos; na cidade do Oeste Paulista a ênclise é um comando no cumprimento da proposta.

Se os Grupos Escolares foram eleitos como meio propagandístico do governo republicano, Mococa manifestava seu comprometimento com as propostas republicanas por meio de ordenação/comando e São José dos Campos se valia do rito cerimonioso da saudação. Não importa, fosse com propostas, fosse com relatos, cada um, a sua maneira, 
teria que colaborar para que essa simbologia fosse mantida e enraizada nas tradições populares.

Portanto, se por um lado a ênclise diferenciava o usuário engajado no sistema de normas e valores republicanos, por outro ampliava o fosso já existente entre as classes sociais que não se beneficiavam do processo escolar de aquisição do valor distintivo da ênclise e tampouco compartilhavam o lócus de sua marcação. 


\section{Capítulo 3 - O repertório compartilhado pelo conteúdo programático}

\section{Introdução}

A batalha simbólica travada pelos Grupos Escolares permaneceu figurada em mais um efetivo arsenal capaz de dar visibilidade à reunião e à formatação de crianças republicanas, cujas avaliações centralizavam esse armamento. $\mathrm{O}$ ensino seriado instaurado pelos grupos possibilitou a formação de classes graduadas que precisavam de um contínuo processo de avaliação e seleção para subirem de estágio. (SOUZA, 2005).

Além dos exames públicos realizados no final dos anos letivos, provas de diversas matérias realizadas mensal e bimestralmente pelos alunos evidenciam modelos de produção dos Grupos Escolares de Campinas, Sorocaba e Tatuí nos anos de 1896 e 1900. Essas amostras, também encontradas no Arquivo Público do Estado de São Paulo, encadeiam temáticas análogas e correlacionáveis.

O conteúdo programático das avaliações permeia diferentes áreas, porém três grandes tônicas lideram sua organização: enquanto algumas disciplinas se utilizam da classificação na tentativa de interpretar o contexto social da época, outras dão destaque à modernização paulista, ecoando na formação do aluno não enquanto indivíduo, mas inserido em um grupo.

A análise sistemática das referidas provas partirá da reunião de aspectos específicos de cada matéria que assumem a condição de correspondentes necessários ao serem relativizados e comparados. Por meio dessa relação, será possível sugerir potenciais interpretações sobre a visão sócio-histórica do período transmitida por esses documentos e sua influência na formação discente. 


\section{Estrutura classificatória: equilíbrio físico e mental evolucionista}

Grandes questões relacionadas ao paradigma evolucionista habitavam o contexto social brasileiro do final do século XIX. O pensamento do período sofria influência da introdução de teorias como o positivismo, o evolucionismo e o darwinismo, cuja reorientação intelectual abandonava a tradição humanista igualitária e se apropriava da ordenação e classificação do naturalista do XIX para explicar a diversidade. (SCHWARCZ, 1993).

Classificar diferenças e consagrar hierarquias pressupunha fortes conexões entre atributos físicos e morais do ser humano. Dessa forma, as análises e comparações, juntamente com processos classificatórios hierarquizantes, de variedades da fauna, flora e até do próprio homem abria possibilidades de entendimento da evolução humana. Particularidades de tal panorama são encontradas nas provas dos Grupos Escolares de Campinas, Sorocaba e Tatuí de forma adequada a cada matéria.

As avaliações da disciplina de desenho realizadas pelos alunos se destacam, dentre outros motivos, pelos traços representantes de uma estrutura central, da qual saem perspectivas que se correlacionam com provas de outras disciplinas. Como centro dessa operação, destacam-se as rosas dos ventos desenhadas pelos alunos do Grupo Escolar de Tatuí, as quais se diferenciam de acordo com o ano escolar em que são produzidas.

A rosa dos ventos é uma imagem representativa dos quatro sentidos essenciais e seus intermediários, ou seja, simboliza a direção. Sua utilização é muito comum tanto em sistemas de navegação marítimos antigos, como em atuais, justamente, por facilitar o deslocamento de uma embarcação por meio de seu contorno em forma de estrela. 
Partindo de um ponto centralizado, a rosa dos ventos abrevia, em um primeiro plano, os quatro principais pontos cardeais: norte, sul, leste e oeste. Secundariamente, surgem outros quatro pontos chamados de colaterais: nordeste, sudeste, noroeste, sudoeste. E, em um terceiro nível, aparecem mais oito pontos denominados subcolaterais.

Dessa forma, uma rede de direção se abre por meio da ordenação de posições feita de acordo com a localização que cada ponto possui em uma circunferência, isto é, conforme a classificação e consequente graduação de seus respectivos ângulos em um círculo trigonométrico.

Embora as rosas feitas pelos alunos denotem diferentes estruturas entre si, a preocupação de se trabalhar, reiteradamente, esse determinado desenho sugere um exemplo prático do método intuitivo de incutir a noção de classificação e hierarquia no desenvolvimento do aluno.

A repetição do método classificatório aplicada nos pontos direcionais da rosa dos ventos em todos os anos escolares do grupo indica não apenas o cuidado em introduzir tais ideias na rede de conhecimento discente, mas também e, principalmente, de modelar condutas pautadas em sucessivos estágios necessários à evolução.

Os desenhos do $1^{\circ}$ ano trabalham apenas com retas, mas se dividem em dois tipos, pois os da $1^{\mathrm{a}}$ série retratam, primitivamente, apenas os quatro pontos colaterais e os da $2^{\mathrm{a}}$ série, um pouco mais aperfeiçoados, acrescentam também os pontos cardeais. 


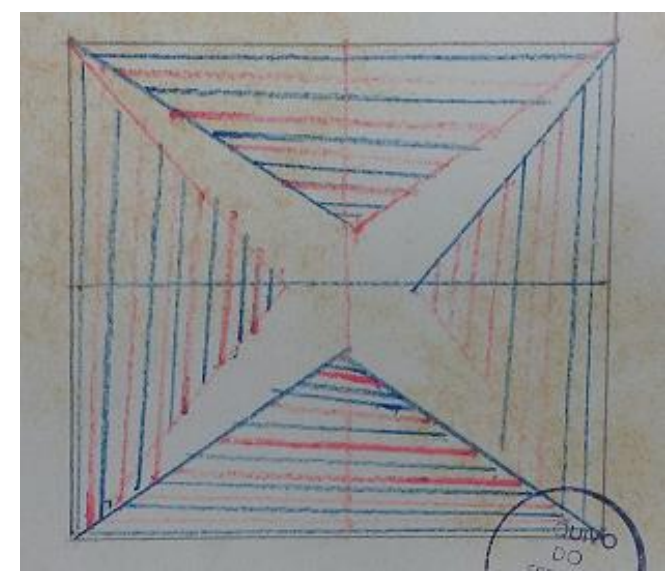

$1^{\mathrm{a}}$ série $-1^{\mathrm{o}}$ ano

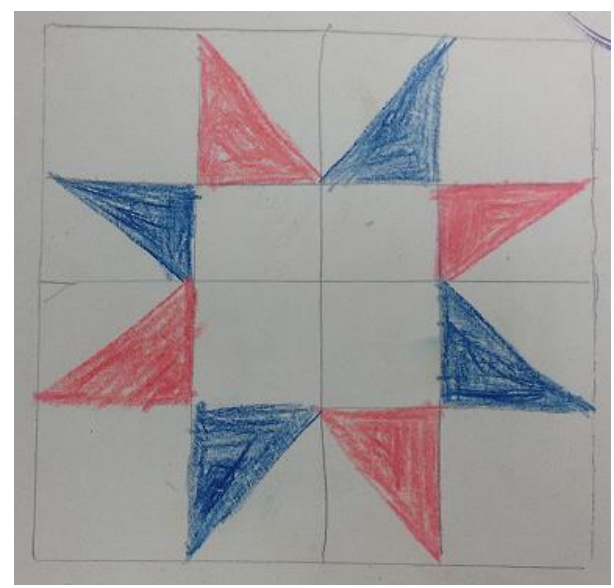

$2^{\mathrm{a}}$ série $-1^{\mathrm{o}}$ ano

Já as representações dos alunos do $2^{\circ}$ ano, além de também serem feitas apenas com linhas retilíneas, são, simetricamente, mais bem delineadas, sendo aproximadas, assim, de um efetivo modelo de rosa dos ventos, fato que clareia o desenvolvimento que os desenhos vão adquirindo a cada ano escolar.

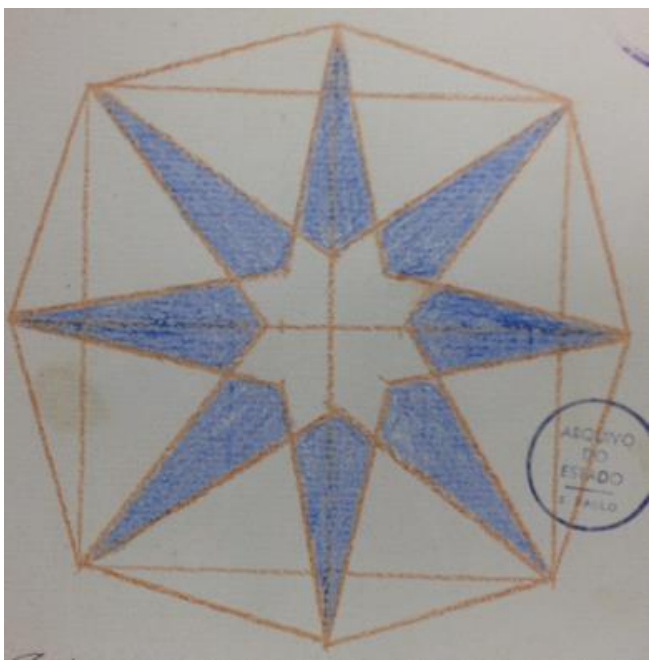

$2^{\circ}$ ano

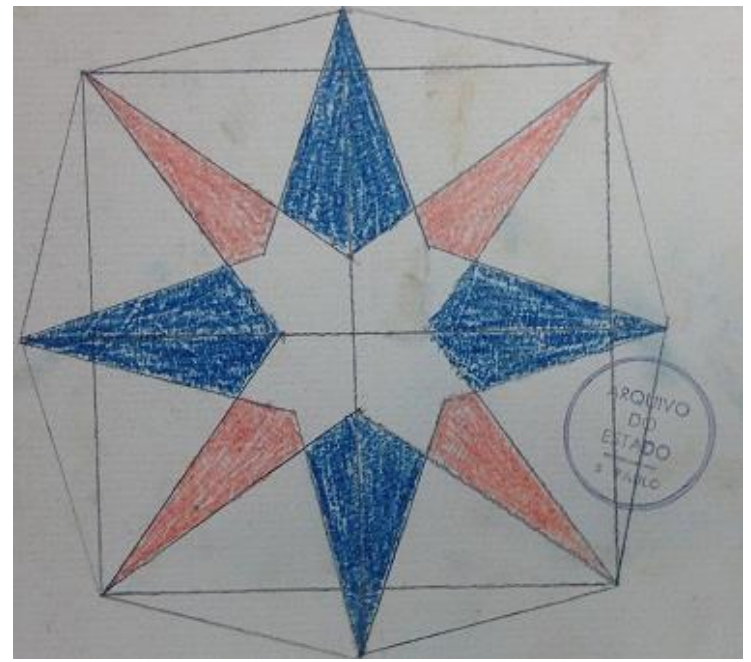

$2^{\circ}$ ano

Não somente com retas, o $3^{\circ}$ e $4^{\circ}$ anos contornam ilustrações muito semelhantes ao aspecto de uma flor. Por acrescentarem mais um item à construção das rosas, uma vez que se beneficiam também de linhas curvas, a evolução percorrida pelos desenhos 
fica, dessa forma, cada vez mais evidente, o que determinaria, assim, a complexidade como critério norteador do caminho evolutivo dos desenhos.

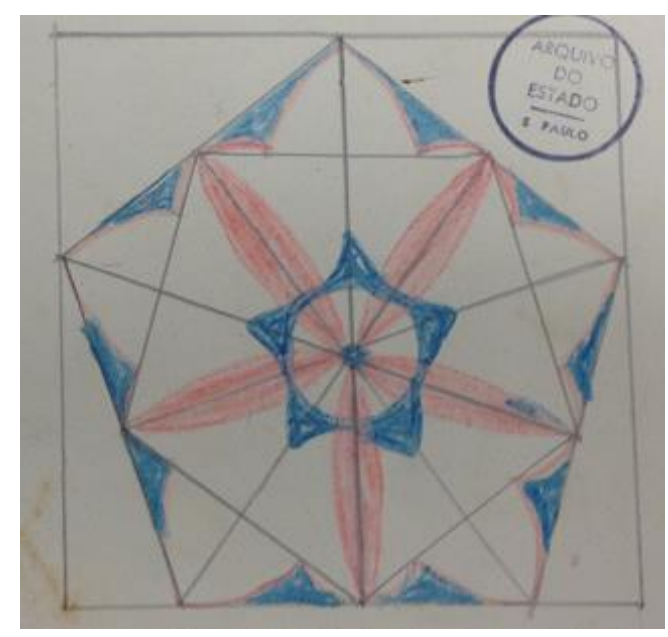

$3^{\circ}$ ano

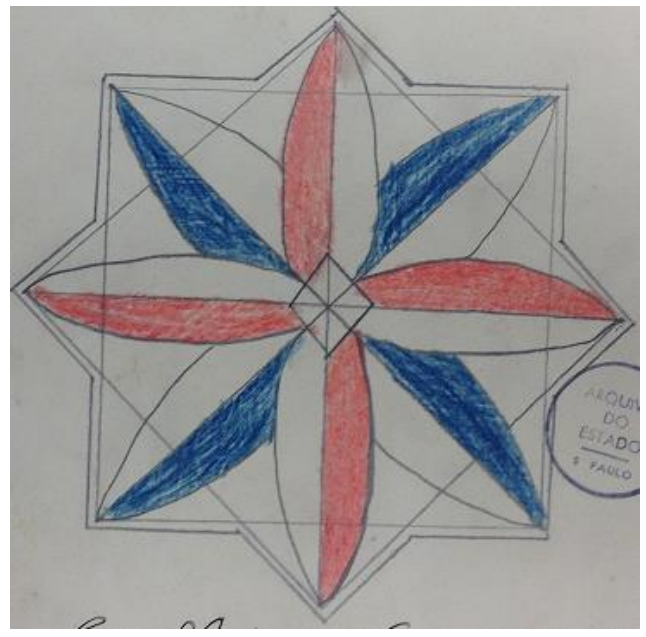

$4^{\circ}$ ano

As diferentes caracterizações expostas remetem ao princípio de uma disposição exata dos pontos direcionais de acordo com a posição em que ocupam, fato que possibilitaria, em tese, todos os pontos da linha do horizonte serem localizados com exatidão.

O eixo norteador das provas de desenho caminha em direção a uma distribuição de posições por meio de um sistema de classificação. Por mais que se distribua pontos em cada desenho de maneira diferente, todos eles sempre partem de um ponto central. Tal perspectiva se torna ainda mais clara com as demais provas encontradas que ora se aproximam de uma flor, ora de uma rosa dos ventos. 

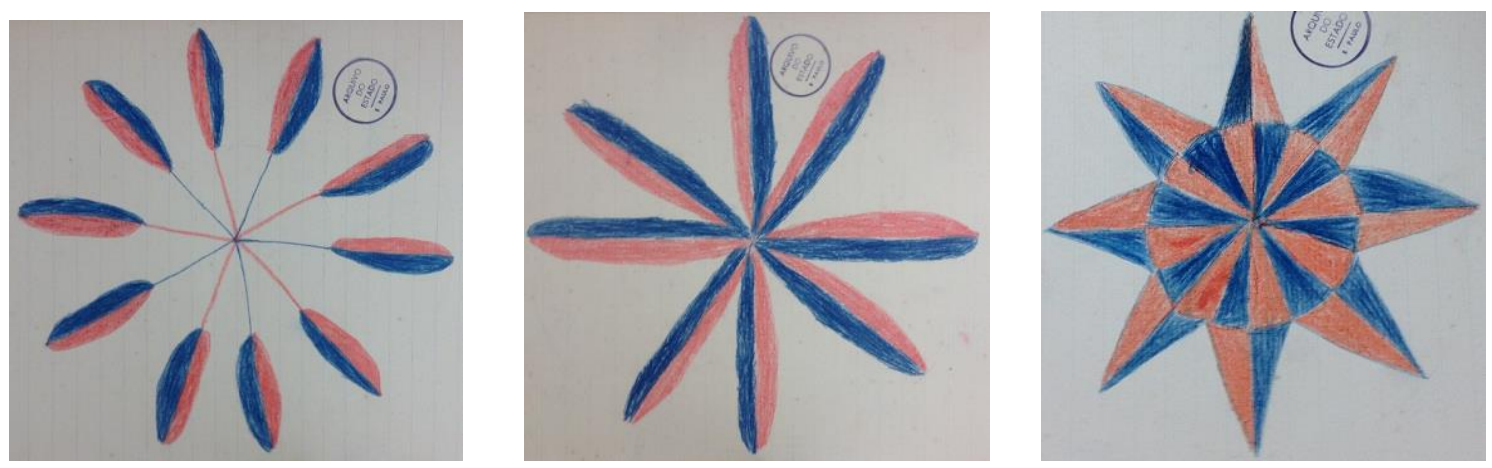

Mesmo assim, é possível constatar que a centralidade é elemento-chave em todas as ilustrações, uma vez que, a partir desse ponto, toda uma rede de distribuição e classificação se desabrocha e é montada. Essa concepção, adaptada a cada contexto, também não foge à regra nas provas das demais disciplinas.

A própria organização dos Grupos Escolares remete a um processo classificatório que distribuía os alunos em séries por idade, nível de aprendizagem e estágio de conhecimento, além de ter sua disposição espacial dividida em seções masculina e feminina.

A passagem do aluno de uma série para outra dependia do seu sucesso ou fracasso medido pelas avaliações. Com isso, a evolução discente se verificava na transição das crianças ao atingir determinado nível do conhecimento, as quais iriam, em tese, gradualmente, se aperfeiçoando.

Portanto, o mesmo se confere nas rosas dos ventos ilustradas. Um caminho evolutivo é esboçado desde os traços mais primitivos feitos pelos alunos do $1^{\circ}$ ano, passando pelas retas mais completas e bem delineadas do $2^{\circ}$. Já as imagens do $3^{\circ}$ e $4^{\circ}$ anos, portadoras de riscos retilíneos e curvos, desabrocham desenhos muito similares a uma flor, ponto de ligação ao eixo condutor da análise em questão. 
As avaliações de Botânica, no que se refere ao estudo de uma flor, apresentam estritas referências à sua constituição estrutural e sistematiza todas as suas principais partes:

Examinando uma flor vemos que Ella esta presa a haste por um filamento chamado "pedunculo". Fazendo continuação com o pedunculo encontra-se um tubo cor verde, e o calice; para dentro do calice nota-se um tubo cor de rosa, é a corolla; para dentro da corolla encontram-se cinco filamentos que são chamados "estames"; bem no centro da flor existe uma pequena columna, é o pistillo. Todas as flores constam de cinco partes que são: cálice, corolla, estames e pistillo. (Grupo Escolar Antônio Padilha - Sorocaba, 1896).

Como na rosa dos ventos, mais uma vez, um componente central aparece. Entretanto, o estudo é feito de fora para dentro. Como camadas de uma cebola, um diagrama floral é organizado, hierarquizando membros que configuram uma periferia ao redor, formada pelos estames, cálice e corola, e isolam, ao centro, a pequena coluna, denominada pistilo.

Esse mesmo tópico é trabalhado nas provas em que outras construções vegetais são retratadas, como por exemplo, descrições do processo de disseminação e germinação das plantas, divisão e nomenclatura dos segmentos de um fruto, de um vegetal, além da definição das dicotiledôneas.

O ramo das dicotyledoneas comprehende 3 grandes grupos que são: $1^{\circ} \mathrm{o}$ das apétalas cujas flores não tem pétalas. $2^{\circ} \mathrm{o}$ das monopétalas cujas flores tem as pétalas ligadas; $3^{\circ} \mathrm{o}$ das polypetalas, cujas flores tem as pétalas distinctas. ( $1^{\circ}$ Grupo Escolar de Campinas - 1900).

Nesse caso, o conteúdo exigido do aluno se resume apenas na divisão e distribuição das plantas com dois cotilédones em suas respectivas categorizações. Ao qualificar cada subgrupo, o exercício da classificação entra em cena a fim de dispor os elementos em hierarquias e, assim, submetê-los a um ramo maior e central, as dicotiledôneas. 
As demais matérias recorriam a essa constante classificação de objetos, sobretudo, Anatomia e Zoologia, cujos textos dos alunos concentram definições das aves, macacos, insetos, estudo dos ossos do corpo humano, inclusive a divisão dos animais em vertebrados e invertebrados.

Assim, pois, animaes formão dois grupos bem distinctos:- $1^{\circ}$ Animaes que têm ossos e são chamados- Vertebrados como a gallinha, o coelho, a cobra etc. $2^{\circ}$ Animaes que não tem ossos e são chamados Invertebrados - como lesma, a minhoca a barata o mosquito etc. Os animaes que têm ossos são chamados Vertebrados porque todos elles tem, como o homem - uma columna vertebral. Os animaes que não têm ossos são chamados invertebrados porque não têm columna vertebral. (Grupo Escolar Antônio Padilha - Sorocaba, 1896).

O vínculo estabelecido com a divisão dos animais em vertebrados e invertebrados, ou seja, pela presença ou não da coluna vertebral, reverbera a noção de classificação observada nas rosas dos ventos e nas flores. Esse agrupamento sistemático é feito de acordo com suas afinidades e/ou características comuns.

Se as linhas presentes na rosa dos ventos dividem uma circunferência $\left(360^{\circ}\right)$ em partes iguais partindo de um ponto central e, assim, indicam o limite e direção dos pontos cardeais, essa centralidade encontra, em transferência à Anatomia e Zoologia, a condição fundamental para um animal ser classificado como vertebrado ou invertebrado: a presença da espinha dorsal.

Se recorrer à hierarquização da fauna e flora confirmava análises deterministas da época e estimulava tentativas de compreensão do próprio homem, exercícios classificatórios característicos das provas dos grupos, portanto, operavam como a transferência para o conteúdo escolar do que se via na sociedade.

A habilidade exigida do aluno era, essencialmente, definir nomenclaturas dadas. Física e Química cobravam, igualmente, apenas definições teóricas sem a aplicação prática que determinada teoria adquiriria em um contexto diário específico. 
A alavanca, na sua mais simples forma, é uma barra inflexível que se firma sobre um ponto fixo denominado ponto de apoio. [...] Conforme a posição do ponto de apoio relativamente a potencia e a resistência a alavanca é de 3 generos. A alavanca do $1^{\circ}$ genero é aquella em que o ponto de apoio está situado entre a resistencia e a potencia. $\mathrm{Na}$ alavanca do $2^{\circ}$ genero o ponto de apoio está na extremidade da alavanca [...] $\mathrm{Na}$ alavanca do $3^{\circ}$ genero a potencia se acha entre o ponto de apoio e a resistencia [...] (Grupo Escolar Antônio Padilha - Sorocaba, 1896).

Uma alavanca tem sua funcionalidade descrita e seus três tipos definidos a partir da posição do ponto de apoio resultante de uma determinada potência (força aplicada) e resistência (peso do objeto a ser movido). Esse ponto se fixa, portanto, em uma localização exata capaz de ceder o equilíbrio necessário entre as forças de ambos os lados.

A figura do centro é apontada também no conhecimento exigido em Química, cuja avaliação cobra o conceito de ponderabilidade baseado no encontro de um centro comum:

Está provado, ha muito tempo, que todas as moleculas dos corpos têm uma tendencia a reunirem-se e persistirem em sua união [...] que todos os phenomenos do movimento podem ser comprehendidos e até calculados, suppondo que todas as partículas da materia são dirigidas por uma força desconhecida para um centro commum. (Grupo Escolar Antônio Padilha Sorocaba, 1896).

A representação de um ponto centralizado é buscada tanto na alavanca como na ponderabilidade acima descrita, mas também pode ser, sobrepostamente, identificado no eixo sustentador de um corpo animal, a coluna vertebral, e no centro irradiador dos pontos cardeais de uma rosa dos ventos.

Quando se fala em posição central, como as representadas pelos objetos das disciplinas analisadas, é possível de se pensar em um eixo, uma região que oferece sustentação e, consequentemente, gerar equilíbrio e harmonia, o qual é estabelecido pelo desenvolvimento normal e progressivo das forças do corpo (Grupo Escolar Antônio 
Padilha - Sorocaba, 1896), processo atingido na ginástica escolar, disciplina introduzida no currículo escolar pelo ensino republicano. (MARCÍLIO, 2005).

Equilibrar as forças do corpo humano era uma tarefa concebida não apenas fisicamente, mas também pela união do completo uso de suas forças espirituais e corporais, cuja falta determina fatalmente uma consideravel diminuição de forças nos orgãos, o desequilíbrio e perturbação das funções naturaes [...] (Grupo Escolar Antônio Padilha - Sorocaba, 1896).

Um exemplo de movimento corporal é encontrado em uma das provas de ginástica, referindo-se aos deslocamentos da cabeça para atingir o referido equilíbrio:

$1^{\circ}$. Voltar a cabeça a direita e a esquerda reassumindo a frente primitiva, em $1^{a}$. posição.

$2^{\circ}$. Flexão da cabeça para a frente, até tocar o peito com a ponta do queixo; e para traz até olhar directamente para o infinito reassumindo a frente primitiva, em $1^{\mathrm{a}}$. posição.

$3^{\circ}$ Flexão da cabeça para a direita e para a esquerda reassumindo a frente primitiva, em $1^{a}$ posição. (idem).

Os exercícios indicados são sempre iniciados e, posteriormente, recolocados nas denominadas primeira posição ou frente primitiva, as quais se pode interpretar como costas eretas e cabeça em posição natural. Tal posicionamento tem como referência o eixo central de sustentação do corpo humano, pois subentende a coluna vertebral plenamente endireitada, fornecendo equilíbrio ao homem.

Dessa forma, a Ginástica, assim como as demais disciplinas, pode ser vista como uma ramificação da perspectiva difundida pelos Grupos Escolares em suas avaliações, já que a centralidade se porta como elemento-chave para a classificação.

Esse exercício é denotado também nas provas de Português, permeando os diversos tipos de análises fonéticas, morfológicas e sintáticas. Além das definições das inúmeras classes de palavras, os exercícios classificatórios roubam a cena, elegem como medular a função ocupada pelo verbo. 
"Cícero era eloquente"

Sujeito é o objecto principal do juizo, a ideia predominante.

Verbo é o nexo que ata o attributo ao sugeito.

Attributo é a qualidade, estado, accidente ou outro qualquer predicado attribuido ao sujeito. (Grupo Escolar Antonio Padilha - Sorocaba, 1896).

Se em uma sentença existem os três elementos acima citados, o verbo aparece como componente central da oração, como ferramenta indispensável para vincular o sujeito ao atributo/predicado.

A maciça classificação, visivelmente cobrada dos alunos, remete-nos a um período de cientistas a postos com suas ideias veiculadas por meio de diversas instituições brasileiras: museus, faculdades de direito e de medicina. Intelectuais que trabalhavam a fim de, liderados por uma ciência positiva e determinista, encontrar o rumo para a nação. (SCHWARCZ, 1993).

Comparar e classificar encontrou no estudo e categorização da fauna e flora caminhos para se chegar ao homem, pois ao recolher, analisar, classificar, hieraquizar e expor, os museus [etnográficos] pretenderam trazer um pouco de ciência e ordem a esse meio tão carente de produções intelectuais dessa categoria. (idem, p. 119)

Nota-se, portanto, um alinhamento dos Grupos Escolares aos perfis temáticos dos centros nacionais de ensino da época, incorporando modelos de análise que revelam a participação do ensino primário republicano em um projeto intelectual maior. Para tanto, assim como o aluno não poderia ser tomado de forma isolada como indivíduo, os grupos deveriam se manter equiparados às demais instituições de ensino republicano. 


\section{Modernização e paulistanidade}

O modelo de produção baseado na divisão e classificação é explorado também na disciplina de Geografia. Entretanto, esse exercício é feito para colocar São Paulo em evidência pela sua centralidade política e socioeconômica. Demarcações territoriais paulistas são encontradas nas provas, pois o estado havia adquirido, na época, posição de destaque devido à valorização de seus cafezais em detrimento das fazendas do Vale do Paraíba.

Sua capital é a bella cidade de S. Paulo, com palácio do governo, acadimia de direito, escola polytechna, escola normal, correio geral, congresso do Estado e muitos arrabaldes importantíssimos, todos ligados á cidade, por linhas de bondes. (Grupo Escolar Antônio Padilha - Sorocaba, 1896).

Todas as temáticas abordadas nas provas focam a modernização de São Paulo. Marcas de grande prestígio como a Academia de Direito, a Escola Normal e a Escola Politécnica são apontadas, isto é, por meio dessas instituições educacionais de grande prestígio, a capital paulista é tida como palco da modernidade, além de sugerir o estado como responsável pelo fornecimento da educação.

A referência às linhas de bonde demonstra a importância que a comunicação possuía naquele momento, pois, em 1892, o sistema de transportes urbanos era melhorado com a instalação de bondes elétricos. (COSTA, 2010:258). As provas, ao retormarem-nas, tendem a passar a imagem de que São Paulo detinha uma moderna infraestrutura, selecionando os bondes como um dos exemplos dessa modernização feita.

Como forma de fixar tal ideia no pensamento dos alunos, um imaginário é montado ao evidenciar os benefícios do progresso aglomerados nos grandes centros que, por se desenvolverem rapidamente, contrastavam-se, nitidamente, com as regiões 
interioranas. (idem). Assim, a importância cedida às cidades grandes estabelece uma oposição à zona rural de maneira tácita, podendo sugerir a equivalência entre zona urbana e civilização.

Porém, a ótica se amplia e passa a mostrar, então, frequentes exaltações ao desenvolvimento e modernização do estado como um todo, desde seus meios de comunicação marítimos e terrestres até suas outras principais cidades de relevo.

No Estado de S. Paulo quantos meios ha? [...] a navegação transatlantica é feita pelo porto de Santos, a costeira é feita em Cananea, Ubatuba, São Sebatião e Santos, a navegação fluvial é feita pelos rios: Tiete, Mogy guassú, Ribeira, Itararé e outros, $[\ldots]$

Quantas estradas de ferro existem no Estado de São Paulo? [...] a Ingleza a segunda que construíram no Brazil, a primeira que construiram no Estado, a Mogyana, a Paulista, a do Norte, a Bragantina, a Itatibense, a Rio Claro, a Sorocabana, a Ituana. (Grupo Escolar de Tatuí - 1896).

A listagem das vias ferroviárias é importante, pois, por meio delas, os produtos paulistas eram escoados para exportação, de tal forma a salientar a produção agrícola do estado: Suas principaes produções vegetaes são café, fumo, algodão, cana de assucar, chá, madeiras de construções cereaes etc. [...] (idem).

Assim, o conteúdo das provas, na tentativa de fazer os alunos adquirirem esse conhecimento, mostra a veiculação da ideia de que São Paulo exercia forte influência na economia com seus produtos exportados; no transporte, com suas linhas de bonde e sua malha ferroviária e fluvial; e na educação, com a presença de renomadas instituições educacionais na capital paulista: Academia de Direito, Escolar Normal e Escola Politécnica.

O elenco e a descrição da navegação e do transporte ferroviário são estratégias para incutir a conectividade entre as cidades paulistas, mostrando, dessa forma, que as linhas de trem possuíam a função simbólica de espraiamento da civilização. 
Apesar de as provas tratarem das ferrovias da época, que se concentravam mais na porção leste paulista, apenas os rios são mapeados. Tal fato causa estranhamento, já que muito se falava em civilização, porém, para enfatizar essa ideia, não é uma produção do próprio Estado utilizada, mas sim um artefato natural.

Por iconicidade, esse artifício evidencia toda a rede de integração das regiões mais desenvolvidas do leste com as menos desenvolvidas do oeste, por meio da qual o processo civilizatório se expande ao transcorrer as ramificações fluviais de forma a atingir todo o território paulista e, assim, mostrar o domínio estatal.

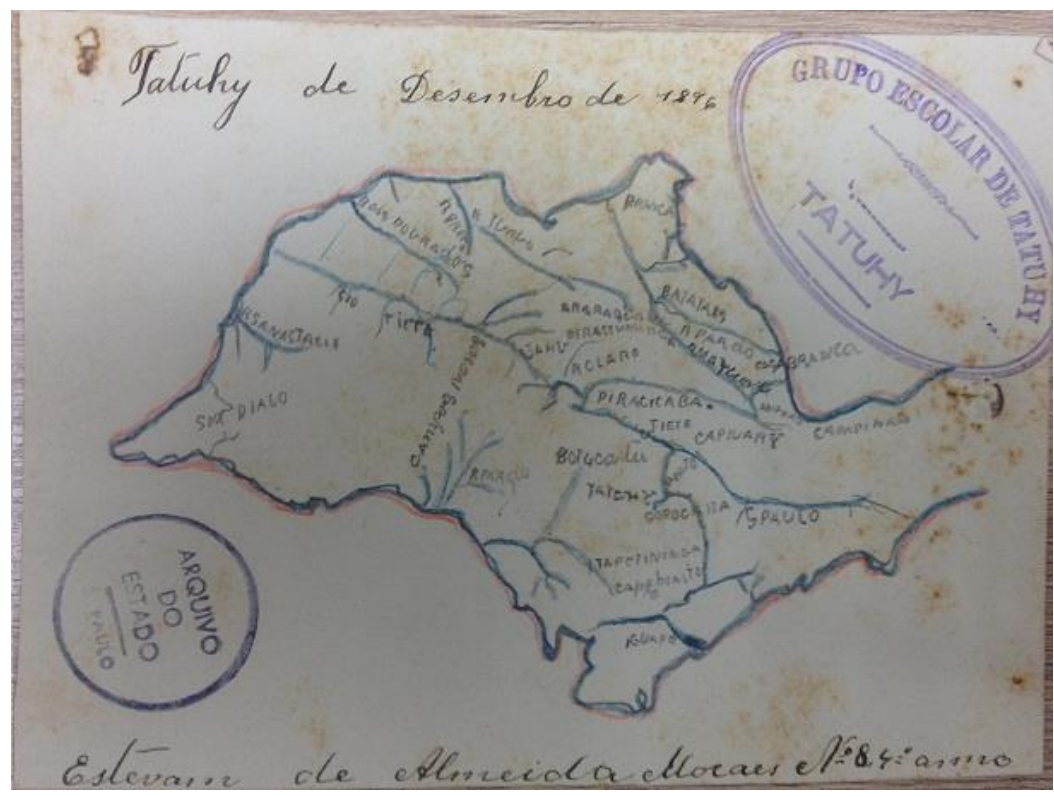

Devido ao foco dado aos grandes centros urbanos por se beneficiarem da ampliação do progresso, estabelecem-se agudas divergências com as demais regiões, no entanto, a adoção dessa perspectiva de interligação entre todos os pontos do estado sugere um alinhamento do interior à modernidade e à civilização.

Ainda por iconicidade, o mapeamento da interligação entre os rios revela não apenas a propagação civilizatória por todo o estado de São Paulo, mas também o sentimento de paulistanidade encerrado pela demarcação de fronteiras. 
O Estado de S. Paulo é limitado ao N. pelo Estado de Minas Geraes, a L. pelo do Rio de Janeiro e O. Atlântico, a O. pelo Matto-Grosso; a S. pelo Paraná. Sua superfície é de quase 300.000 kilometros quadrados no total. [...] (Grupo Escolar Antônio Padilha - Sorocaba, 1896).

Nas demais cartografias do mesmo grupo, o Brasil aparece inserido na América do Sul, destacando o tamanho que aquele possui nesta. Por não estar sozinho, nem se fragmentar em estados, surge a ideia de projeção do país na América tal como se fosse seu próprio coração (é emblemática a cor avermelhada), apropriando-se, assim, da perspectiva nuclear, anteriormente, atestada pelas rosas dos ventos.

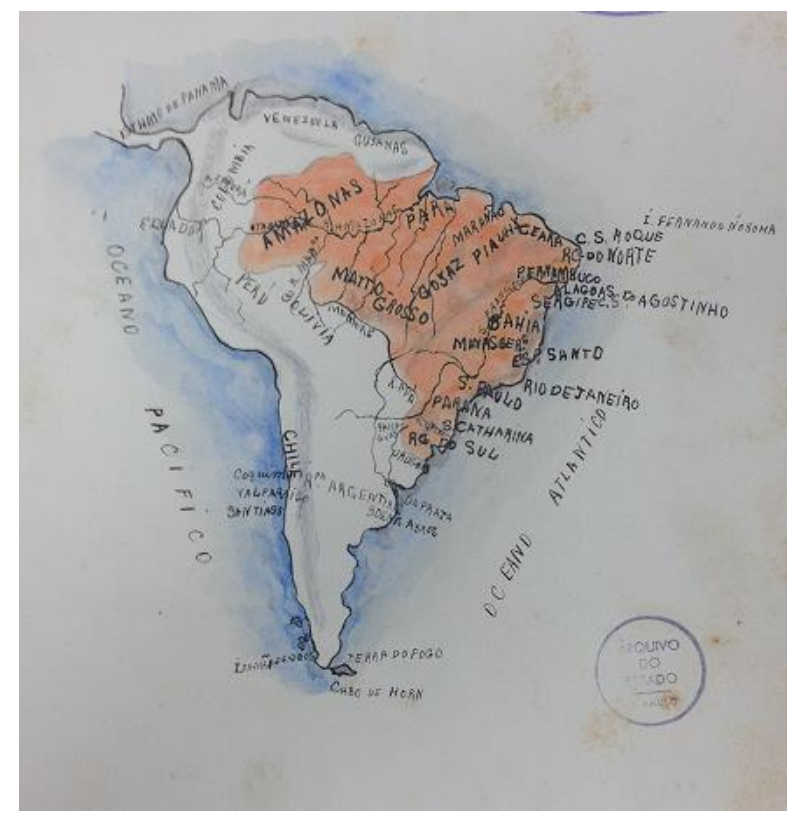

Curiosamente, a fronteira brasileira em relação aos demais países sul-americanos não é demarcada. Tal ausência, juntamente com a ideia do Brasil como coração americano, suscita uma expansão voltada para o interior da América do Sul, concepção presente no imaginário da época, no qual o olhar do país passa a focar não somente a Europa, mas também para dentro do continente.

Essa reversão de olhares foi observada por Nicolau Sevcenko nas obras de Euclides da Cunha e Lima Barreto, os quais manifestavam simpatias, respectivamente, 
pelo oceano Pacífico e pelo oceano Atlântico. Para o primeiro, o Pacífico representa o ponto máximo da evolução e, para o outro, o Atlântico simboliza a imigração originária da nação. De qualquer forma, possuíam um ponto em comum:

Revelava-se nas suas obras [dos dois] o mesmo empenho em forçar as elites a executar um meio-giro sobre os próprios pés e voltar o seu olhar do Atlântico para o interior da nação, quer seja para o sertão, para o subúrbio ou para o seu semelhante nativo, mas de qualquer forma para o Brasil, e não para a Europa. (SEVCENKO, 2003:145).

Embora a preocupação de ambos os escritores não seja a mesma da elite (à qual não pertenciam), pois pensavam em uma ocupação interiorana como forma de desenvolvimento e melhora das condições socioeconômicas, não é o que o mapa mostra. A proposta que o permeia é de um desejo imperialista de expansão territorial não só do interior, mas também da América do Sul.

Outra leitura interpretativa, sem anular a primeira, para a ausência de contornos brasileiros se deve ao fato de que suas regiões fronteiriças não eram muito bem delimitadas, ou seja, uma época em que os limites do Brasil ainda estavam sendo definidos, haja vista que após a proclamação da República, o Governo Provisório continuou prosseguindo a execução do programa imperial de fixação definitiva das divisas brasileiras. (JORGE, 1999).

Nesse ponto temático de ampliação de territórios, os Grupos Escolares se alinham, novamente, ao programa das renomadas instituições educacionais do Brasil, no caso, o Instituto Histórico e Geográfico Brasileiro (IHGB), cujos textos privilegiam questões de extensão e fixação de fronteiras. Vale lembrar que:

Os textos de Geografia [...] cumprem um papel bastante específico; boa parte deles referem-se a questões territoriais e de demarcação de limites, ganhando assim uma função claramente pragmática dentro do contexto específico da época, em que vários litígios desse tipo estavam em andamento. Um exemplo relevante é a famosa "questão do Acre" defendida pelo barão do Rio Branco, sócio efetivo do IHGB. (SCHWARCZ, 1993:143). 
Incorporar novas regiões ao país simbolizava não ceder às pressões do imperialismo europeu e de fortalecer a posição do Brasil na América do Sul, pois o barão do Rio Branco estava convicto de que os países mais fortes buscavam se sobrepor aos mais fracos. (DORATIOTO, 2012).

Tratados de limites passaram a ser negociados pelo conselheiro republicano Visconde do Rio Branco, o qual não vacilou em assumir a pesada responsabilidade da defesa dos direitos do Brasil. (idem, p. 30), e participou ativamente do estabelecimento de divisas do país com a Argentina, Bolívia, Colômbia, Peru e com as Guianas Francesa e Inglesa.

Porém, a figura de Rio Branco não era vista somente como portadora de uma conduta pacífica nessa busca por novas fronteiras. Com efeito, as memórias de Pedro Nava depõem certa contrariedade da época ao avanço ilegítimo das regiões limítrofes brasileiras.

[...] [Antônio Salles] condena a movimentação de nossas tropas em direção à fronteira do Peru, endossa a opinião dos que achavam menos legítima a nossa posição no Acre e ataca Rio Branco como autor de uma política arrogante com relação aos outros países da América Latina. (NAVA, 2000:282).

A simbologia de afirmação brasileira e da própria América é detectada em duas provas de Desenho encontradas, nas quais se apresentam navios a vapor - outro símbolo do aperfeiçoamento do sistema de transportes, em cujos mastros estiram-se bandeiras do Brasil e da Colômbia. 


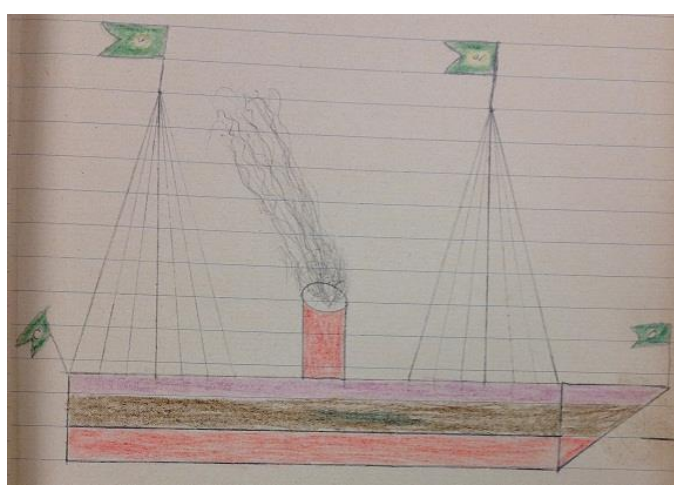

Brasil

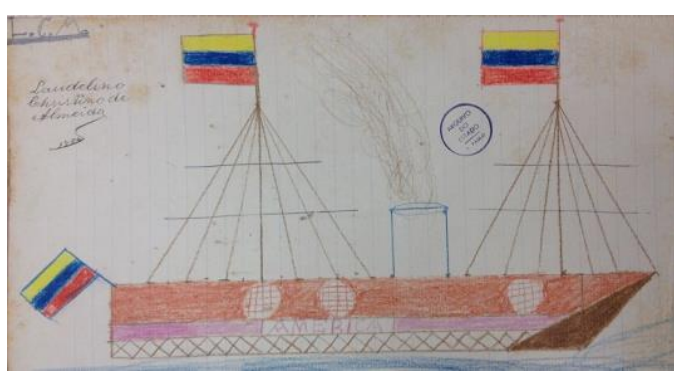

Colômbia

Na conjuntura de grandes movimentos imperialistas, se sobrepõe um quadro de ampliação de mercados (COSTA \& SCHWARCZ, 2000), fato que explica, na prova de Desenho, a presença de navios a vapor com as bandeiras brasileira e colombiana. Tal visão imperialista retirada da figura de um navio é reforçada em um discurso do diretor da Escola Normal Caetano de Campos, Oscar Thompson, em 1902: ${ }^{24}$

E balouçando-se sobre ondas argênteas um navio em demanda de terra... [...] Essa imensidão de água [...] cavando em seu próprio seio sulcos profundos, capazes de tragar outros mundos [...] olhai para aquele navio [...] ele partiu de terras longínquas em busca de outras terras [...] Força, coragem e perseverança aproximam aquele navio da terra almejada.

Apesar de a ampliação de mercados se correlacionar com o contínuo processo de produção dos símbolos mais representativos do mundo moderno (a eletricidade, os automóveis, o telégrafo, o cinema, a máquina a vapor, a televisão, o estetoscópio, a fotografia, a anestesia, a penicilina, os adubos artificiais, o fogão a gás, o refrigerador, a caixa registradora, a aspirina etc. (COSTA \& SCHWARCZ, 2000), toda essa aguda modernização instrumental não borbulhava em nenhuma das avaliações dos Grupos Escolares.

\footnotetext{
${ }^{24}$ Esse discurso é pronunciado na Escola Normal Prudente de Moraes. É preciso lembrar que as Escolas Normais formavam professores que assumiam a regência das turmas dos Grupos Escolares.
} 
Da modernização citada, somente o telefone e o telégrafo aparecem nas avaliações dos grupos, de forma a ressaltar o papel que exerciam para manter todos os pontos do estado de São Paulo em plena comunicação.

Quaes são os meios de communicação do Brasil?

[...] temos o telegrapho terrestre e o telegrapho sub-marino [...]

No Estado de S. Paulo quantos meios [de comunicação] ha?

São todos os meios já citados [...] o telegrapho terrestre põe em communicação as cidades do Estado [...] o telephone que communica as casas d'algumas cidades, e o que liga S. Paulo ao Rio de Janeiro, isto é, as duas cidades. (Grupo Escolar de Tatuí - 1896).

O progresso que transparece nas provas está, portanto, circunscrita às funções sociais do Estado que, por cálculo, propagandeia a si mesmo ao propor como conteúdo programático conhecimentos correlacionados com a ideologia republicana.

Com efeito, por exporem o contexto específico da época, em que várias causas de delimitação de fronteiras com os demais países sul-americanos se encaminhavam, o Brasil era retratado nos mapas feitos pelos alunos do grupo exatamente como um país em expansão e em busca de sua modernidade, fato que efetivava, assim, a propaganda republicana na formação do aluno.

\section{Formação de almas civilizadas}

Temas relacionados ao descobrimento do Brasil, biografias dos respectivos protagonistas da história nacional, feitos como a conspiração de Tiradentes, expedições e delimitações territoriais brasileiras e da América do Sul, são recuperados pela disciplina de História que tratava de eventos e personalidades que teciam e exaltavam a história oficial do país. 
A concentração temática dialoga com os preceitos traçados pelos institutos históricos que objetivavam ordenar eventos e construir uma história da nação. ${ }^{25}$ Dessa forma, as provas de História privilegiam episódios significativos do período colonial, como o próprio descobrimento e as diversas expedições feitas no país.

Christovão Colombo era um Italiano que morava em Genova e foi quem descubrio a America no dia 12 de Outubro de 1492. [...] Pedro Alvares Cabral foi o almirante Portuguez que descobrio o Brazil à 21 de Abril de 1500. [...] O commandante da $1^{\text {a }}$ [expedição] foi André Gonçalves, da $2^{\mathrm{a}}$ foi Goncalo Coelho, da $3^{\mathrm{a}}$ foi Christovão Jacques e da $4^{\mathrm{a}}$ foi Martim Affonso. (Grupo Escolar de Tatuí - 1896).

Além de ressaltar a identidade nacional, personagens também aparecem centralizando a história pátria, retomando a busca pela reconstrução do mito de origem, que recai tanto no âmbito das cidades, povos e nações, quanto nos regimes políticos. (CARVALHO, 1990).

As avaliações não atestam datas da República, o que sugere que havia um interesse maior em esconder sua datação recente e, por meio do mito, fincar raízes sólidas em um momento bem anterior. Dessa forma, os indícios mostram a dificuldade em colocar datações no sentido de afastar as inseguranças de um período político instável e incerto, consolidando, assim, as bases do novo governo.

A legitimidade do novo governo é feita pelo recurso ao mito de origem republicano que busca sedimentar seus pilares na colonização brasileira com as figuras de Colombo, Cabral e dos expedicionários André Gonçalves, Gonçalo Coelho, Christovão Jacques e Martim Affonso. A partir de então, o destaque é travado na Inconfidência Mineira.

\footnotetext{
25 Tais institutos adequavam seu trabalho épico e nacionalista a um rigor documental até então novo para a época (SCHWARCZ, 1993), preocupação que emerge com a criação de revistas que permearam o mundo acadêmico e influenciaram a adoção desse projeto patriótico pelos livros didáticos oficiais.
} 
Conspiração de Tira-dentes

Joaquim José da Silva Xavier, por apellido Tira-dentes, official de cavallaria teve por convininiente erigir uma republica em Minas modelada pela dos Estados Unidos. [...] Os principaes conjurados foram condenados ao ultimo suplicio, mas commutou-se-lhe a pena para as costas da Africa. O único que foi condemnado a forca foi Tira-dentes sendo a sua casa arrazada e os seus filhos declarados infames. (Grupo Escolar Antônio Padilha - Sorocaba, 1896).

A recuperação da Inconfidência na construção de um herói reflete, em particular, a busca pela adesão popular na composição do imaginário republicano. Desse modo, a estratégia usada para atingir a massa popular pautou-se na ressignificação de Tiradentes, também associada ao espectro de Cristo, adquirindo, assim, uma conotação religiosa.

Mais que isso, Tiradentes reforça o mito de origem republicana, pois, devido à falta de participação pública e a necessidade de se apagar os resquícios do regime monárquico, deveria se estabelecer uma visão dos fatos que legitimasse a situação vencedora e, no caso da criação de novos regimes, o mito estabelecerá a verdade da solução vencedora contra as forças do passado ou da oposição. (CARVALHO, 1990:14).

Nesse sentido, os heróis se tornam ferramentas eficazes para atingir a cabeça e o coração dos cidadãos. Heróis são símbolos poderosos [...] de identificação coletiva [...] herói que se preze tem de ter, de algum modo, a cara da nação [...] ou de refletir um modelo coletivamente valorizado. (idem, p. 55).

A adoção de Tiradentes como herói se deve também à sua associação com a área pela qual lutou para ser independente: Minas Gerais, Rio de Janeiro e São Paulo. Essa região era o centro político do país e o apelo à sua imagem nas provas dos grupos garante o constante reforço do imaginário popular preenchido por um personagem nacional que passou a representar o regime republicano. 
O conteúdo das provas sugere que a República deve ser interpretada como tendo origem remota, fincada na colonização e heroificada por Tiradentes. Nesse momento, atinge-se o ponto máximo da "história" republicana, a qual é vista como contínuo do período colonial, já que se pretende ocultar a Monarquia, como se ela não tivesse existido.

O mito de origem da República amarra, portanto, eventos, temporalmente, distantes a fim de sustentar o projeto republicano e tentar endossar sua base popular até então inexistente. Para tanto, mitificar a versão dos fatos para atingir a dimensão desejada no imaginário escolar transmitiria, assim, a ideia de superioridade e consolidação do novo governo.

Há uma identificação entre tal mito e a origem da nação, pois, de acordo com Schwarcz (1993), a periodização histórica dos institutos busca na "descoberta portuguesa do país" a origem da nação, a partir da qual os acontecimentos ordenados passam a registrar episódios nacionais que possibilitavam a comparação com grandes temas de uma história, especialmente, europeia. É nessa chave de leitura que se pode explicar a retomada de eventos do período colonial.

[...] nosso grandioso paiz esteve por muitos séculos ignorado dos povos civilisados, não era mais que grandiosas mattas, habitadas por numerosas tribus de indios selvagens, anthropophagos e feroses. [...] Estes factos, porem, despertaram o interesse do referido governo o qual mandou expedições onde vieram os valentes Diogo Alvares, Thomé de Sousa, Christovam Jaques, Martim Affonso e muitos outros. [...] Hoje vemos este nosso paiz no estado de adiantamento, civilisação e riquesas que muito breve poder-se-há igualal-o as grandes potencias Europeas. (Grupo Escolar Antônio Padilha - Sorocaba, 1896).

Além de demonstrar que o progresso muito próximo estava perto de se equiparar ao dos países europeus, a chegada da população branca representava algo, se não primordial, pelo menos, importante no processo civilizatório do país. Há que se lembrar 
que os referidos índios antropófagos foram postos como selvagens, pois representavam o estágio atrasado em que o Brasil era colocado.

Denominados de botocudos, eram equiparados a outras raças devido ao seu grau de inferioridade intelectual e suas habilidades muito limitadas, o que tornava, de acordo com cientistas da época, difícil de evoluírem rumo à civilização. (SCHWARCZ, 1993).

[...] enviou o governo de Portugal seis missionários jesuítas sob a direcção de Nóbrega, encarregados especialmente da cathequese dos selvagens. (Grupo Escolar Antônio Padilha Sorocaba, 1896).

O homem branco, na figura do português simbolizava, portanto, o contato com o civilizado e constituía a solução para tirar o país da posição de atraso, uma vez que o mito de origem fundado na colonização tem por objetivo colocar em relevo o processo civilizatório operado no país pelo branqueamento da população desde as primeiras expedições realizadas.

Já que, por cálculo, o novo governo era constantemente exaltado a fim de ganhar aderência popular, talvez o que se queria encaixar no imaginário popular pode ser resumido na equação: República = civilização, trabalhando tais conceitos como sinônimos.

Tal ponto é reforçado pela ideia da imigração europeia nas provas de Desenho, as quais apresentam navios em pleno funcionamento, e por se diferenciarem com relação à bandeira que comportavam, é possível sugerir que representavam as massas de imigrantes que chegavam ao Brasil no final do século XIX. 


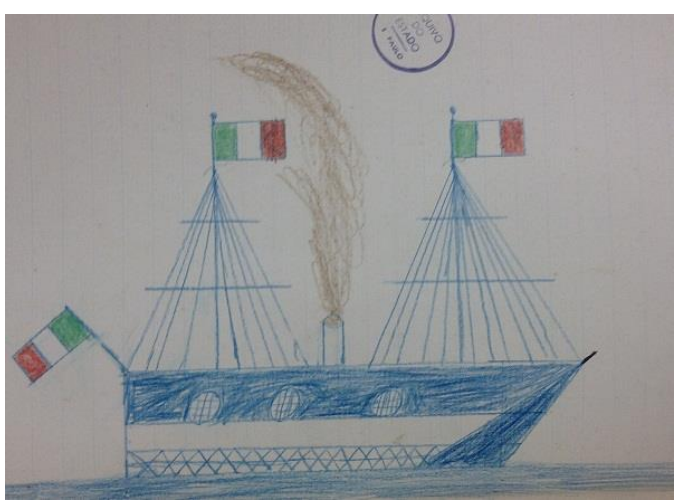

Itália

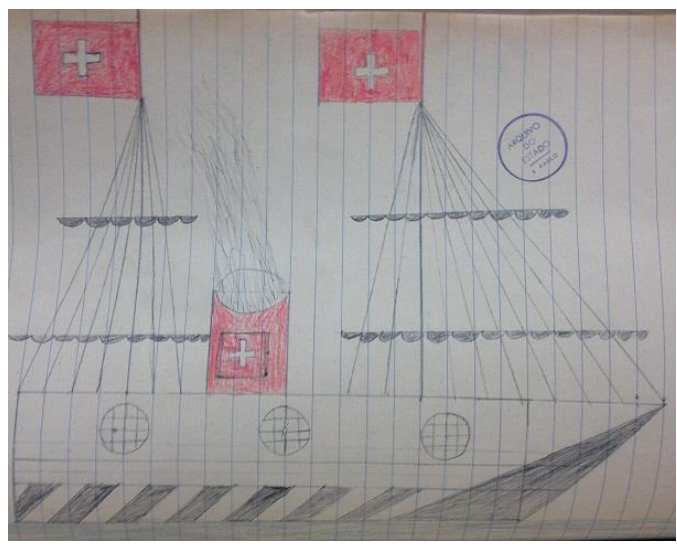

Suíça

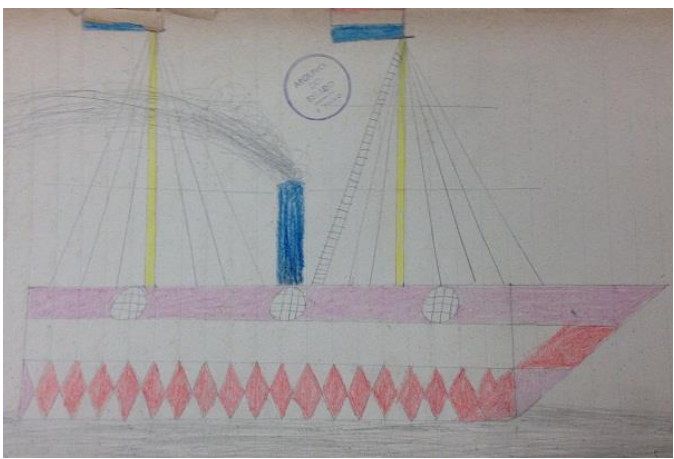

França

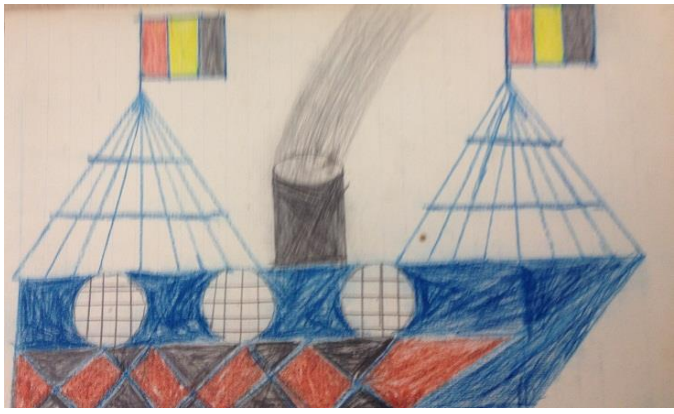

Bélgica

Se, em um primeiro momento, o branqueamento da população deu início ao processo civilizatório do país, posteriormente, ele indica também, enfatizado pelas figuras dos navios, a chegada do movimento imigrante. Dessa forma, por viabilizar ambas as etapas, a figura do emblemático navio parece ser o elemento que melhor representa a civilização.

Os navios trazendo os imigrantes para o Brasil denota além da mistura de nacionalidades característica do período, a efetiva modernização que se instaurava. Essa correlação entre navio-modernidade-civilização é feita por Carlos, personagem de 
Menino de Engenho, ${ }^{26}$ ao narrar os relatos da prima Clara, representante do elemento civilizado, a qual se fixa nos detalhes de suas viagens de navio.

Para mim, a visita viera me aperrear o coração de menino. Maria Clara, mais velha do que eu, andava comigo pela horta. Menina da cidade, encontrara um bedéquer amoroso para mostrar-lhe os recantos de Santa Rosa. Queria ver tudo - o rio, os cajueiros, o cercado. [...] Ela me contava as história de suas viagens de mar, pintava-me o vapor, os camarotes, o tombadilho e o mar batendo no olho de vidro das vigias. (REGO, 2012:112-3).

As ideias de civilização e de modernização não são apenas marcadas na vivência da cabine ou do tombadilho dos navios, mas também na função comercial que esse meio de transporte assume na virada do século. Alguns escritos encontrados na prova de caligrafia vinculam também aos navios a ideia de recebimento da carga voltada para a exportação: Minha prova não está boa / Eu não vou ver o navio no mar / Eu não vou ver o navio receber carga (Grupo Escolar de Tatuí - 1896).

Nesse sentido, a modernização do país era representada pelo carregamento dos navios de produtos voltados para a exportação, ou seja, marcando a presença do Brasil na balança comercial em que não somente importa, como também exporta bens e produtos.

Assim como os navios conectam o Brasil ao mundo civilizado, e a malha fluvial mapeada e malha ferroviária descrita nas provas é usada simbolicamente para interligar pontos distantes do núcleo citadino em que vigora a civilização, a língua homogeneizada e unificada é instrumentalizada para a construção da identidade coletiva, alicerce da formação de almas civilizadas (CARVALHO, 1990). Essa perspectiva é exaltada de forma explícita e, mais uma vez, a história aparece como símbolo do patrimônio nacional:

A pátria é o paiz em que nascemos [...], cuja língua fallamos, cujos costumes adoptamos [...] de que somos filhos, de que

\footnotetext{
${ }^{26}$ Livro publicado em 1932.
} 
somos cidadãos, de que partilhamos as glórias como as desgraças, cuja historia é o nosso patrimônio, cuja bandeira é a nossa honra. (Grupo Escolar de Campinas - 1900)

O conceito de unidade do país é explorado nas provas de outras disciplinas, nas quais valores são conectados permeando o sentido de pátria e a necessária existência do sentimento de comunidade, de identidade coletiva e o consequente pensamento moderno da época de pertencer a uma nação:

A língua e a religião são as duas cadeias de bronze que unem no correr dos tempos as gerações passadas as presentes; e estes laços que se prolongam atravéz das eras são a patria. [...] é a oração ensinada a balbuciar por nossa mãe a língua em que pela primeira ella nos disse: meu filho (Grupo Escolar Antônio Padilha - Sorocaba, 1896).

Além da língua e da religião, o pertencimento a uma nação invoca o elemento cidadão, figura constantemente referenciada nas provas como um homem capaz de bem conhecer sua estrutura e as maneiras de mantê-la em boas condições de saúde. Tais preceitos são explanados em uma das provas de ginástica: A gymnastica escolar tem por fim desenvolver d'uma maneira normal e progressiva as forças do corpo, e a estabelecer, o seu equilíbrio e harmonia (Grupo Escolar Antônio Padilha - Sorocaba, 1896).

O perfil do bom cidadão tem por padrão o equilíbrio físico e mental. O homem deveria ser ativo, inteligente e de bons costumes, valores exigidos na prova de caligrafia, pois, assim, no momento da cópia, feita com calma e atenção, o aluno assimilava intuitivamente tais exigências:

Precisa-se de um menino activo, inteligente e de bons costumes. Mas qual o menino, que satisfaz a taes condições?

Um menino ACTIVO é o que, de boa vontade, faz tudo quanto se lhe incumbe, e que se não desalenta diante da menor dificuldade com que depare. (Grupo Escolar de Tatuí - 1896). 
Obedecer a esses preceitos era sinônimo de partir em busca e, finalmente, entrar no caminho do progresso para, assim, se tornar um cidadão direito. Além disso, algumas outras considerações eram transmitidas com sentido de dever a ser cumprido:

Deve respeitar a religião, obedecer as leis do estado e não abusar das liberdades que ellas concedem. Dar bom exemplo para que não o censurem, ser grato e reconhecido, odiar os vícios e a calunia, não ouvir a intriga, nem praticar a vingança, cumprir rigorosamente os deveres do seu estado e posição, ser respeitoso para com os superiores e afável para os iguaes ou inferiores. (Grupo Escolar Antônio Padilha - Sorocaba, 1896).

A referência às leis do estado evidencia que o aluno deveria, por meio da obediência a tais resoluções, adquirir uma conduta ordeira para que, dessa forma, conseguisse alcançar o posto de bom cidadão republicano. Nesse percurso o descaminho era passível de correção, desde que, obedientemente, se reconhecesse o erro - uma confissão de culpa - e se realinhasse em direção do caminho da boa moral e dos bons costumes:

Meu estimado pae.

O senhor tem toda razão; é certo que eu descuidei-me um pouco dos meus estudos: confesso que perdi algum tempo bem precioso. [...] Peço-lhe, pois, que me perdoe e suspenda por algum tempo o mau juízo que faz de mim: prometto rehabilitarme dentro em pouco no seu conceito. Na confissão da minha culpa já dou a meu pae a garantia da minha rehabilitação; hei de rehabilitar-me em pouco tempo e readquirir a sua confiança. [...] Creia-me sempre.

Seu filho obediente, Dagoberto Pires de Almeida.

É emblemática a redação de cartas direcionadas ao pai, autoridade familiar ao aluno, como estratégia de composição da relação paternalista entre cidadão e Estado, em que o filho deve se esforçar, se redimir, se reabilitar para que possa ganhar a confiança e o bom juízo do pai-Estado e, assim, alcançar na pia batismal dos estudos o título de cidadão, não no sentido político do termo, mas no sentido cultural de homem civilizado. 
Como queriam disseminar uma mentalidade civilizatória por entre os alunos dos grupos, a imagem transmitida pelo conteúdo dessas avaliações era de que o Estado provia a educação e caberia a eles se dedicarem a fim de não saírem da ordem instituída. Portanto, ao alcançar o imaginário das crianças, a escola as forma(ta)ria nos moldes ordeiros do novo governo republicano.

A forma(ta)ção poderia, como vimos, encontrar obstáculos os quais eram superados com a correção de rotas ou com a gradiência dos passos a serem dados. Essa perspectiva está em consonância com o modelo evolucionista. Afinal, em um momento marcado pelos conceitos de civilização e progresso como modelos universais, a evolução do homem era concebida como um desenvolvimento de estágios sucessivos, os quais seguiam determinada direção e iam sempre do mais simples ao mais complexo (SCHWARCZ, 1993), assim como o processo evolutivo na construção das rosas dos ventos analisadas e no branqueamento da população, ocorrido desde a chegada dos primeiros colonizadores.

Se os brasileiros mais primitivos são retratados nas avaliações como os índios botocudos, o processo civilizatório só foi possível com a chegada dos brancos, os quais retiraram o país da posição de atraso: Hoje vemos este nosso paiz no estado de adiantamento, civilisação e riquesas que muito breve poder-se-há igualal-o as grandes potencias Europeas. (Grupo Escolar Antônio Padilha - Sorocaba, 1896).

Posteriormente, os imigrantes europeus, cujo movimento é retratado pelos navios a vapor, recuperam o mito de origem enraizado na colonização ao endossar a continuidade do processo civilizatório viabilizada, novamente, pelo branqueamento da população brasileira. 


\section{Intuindo conceitos}

Manter a ordem social e reprimir qualquer descaminho era objetivo do governo republicano que tinha como intuito, por meio da obediência e disciplina, modelar formar almas (CARVALHO, 1990) - os alunos-cidadãos da forma almejada. Assim, sendo os Grupos Escolares criação da Primeira República e a pedra de toque das escolas graduadas, a seriação do ensino e o método intuitivo neles se encerravam.

Essa nova estrutura e concepção de escola via no método intuitivo a porta de saída para abandonar a aprendizagem focada na memorização e repetição de conteúdos e corrigir a baixa competência dos alunos, apostando no desenvolvimento da intuição e dos sentidos para assimilar todo e qualquer conhecimento. (SOUZA, 2005).

$\mathrm{Na}$ finalidade de abolir o sistema anterior e liquidar com os vestígios monárquicos, ao ser mais prático do que teórico, o processo intuitivo resultaria no desenvolvimento gradual das faculdades discentes, implicando, dessa forma, no uso de um conjunto de materiais voltados para o andamento desse modelo de ensino como, por exemplo, espaços apropriados com diferentes funções: amplas salas de aula, anfiteatros, laboratórios, pátio para recreação etc.; acervos e objetos adequados: manuais de ensino, mapas, globo, tubos de ensaio, microscópio, esqueletos etc.

Porém, a deficiência de material apontada pelos diretores nos relatórios analisados revela a dificuldade em seguir o programa educacional instituído. Pelas reclamações serem mais de ordem física do que didática, percebe-se que os diretores estavam mais interessados na visibilidade que $o$ espaço daria às iniciativas governamentais.

Justamente por isso, tendo em vista o paradigma indiciário de Ginzburg (1989), ao considerar as pistas que revelam o desvio de interesses por parte da direção dos 
grupos, constata-se a falha do método intuitivo, já que ele requer um conjunto de elementos para seu efetivo funcionamento, composto por material didático e espaço físico adequados.

Nesse panorama, a cópia surge como estratégia adotada pelos professores para resolver o impasse da falta de material didático. Revelada nas provas analisadas neste capítulo, a reprodução de modelos iguais, não apenas dentro de um mesmo ano escolar, mas também entre os outros, passa a ser a metodologia de ensino republicana em contraposição ao do período monárquico.

Ao copiar determinados textos dados, o aluno passa a ter acesso aos conceitoschave veiculados pelas avaliações: classificação, hierarquia, modernidade, civilização, ordem, disciplina, progresso etc. Como todos os conteúdos programáticos das diversas disciplinas abordam essas temáticas, em sua reprodução, a criança entrava no sistema ao assimilar intuitivamente o conhecimento colocado.

Nesse sentido, a cópia pode ter sido uma estratégia tributária ao método intuitivo, o qual deveria estar pautado mais na empírica do que na teoria, porém os Grupos Escolares, ainda assim, reproduzem o antigo sistema de memorização só que agora em outra modalidade, pois passa da prática da repetição feita oralmente para a escrita.

Se o aluno tinha acesso aos conteúdos intuitivamente e o sistema era por cópia em todas as matérias, é possível inferir que os diferentes padrões linguísticos, encontrados nos relatórios analisados, também estavam sendo veiculados nessa mesma reprodução.

No entanto, as provas recuperadas são pertencentes aos Grupos Escolares de Campinas, Sorocaba e Tatuí, cujos dados linguísticos referentes à colocação pronominal em orações infinitivas preposicionadas são suficientes para análise apenas no segundo 
grupo em questão (Sorocaba). Infelizmente, não foram encontrados relatórios dos diretores de Sorocaba, impossibilitando, assim, a comparação de amostras e a confirmação ou não do modelo linguístico utilizado.

Nas avaliações do grupo de Sorocaba, vislumbra-se o padrão da escrita dos parlamentares brasileiros (OLIVEIRA, 2014a) e dos escritores "calígrafos" (OLIVEIRA, 2014b): ${ }^{27}$ ênclise categórica com a preposição $a$ e predomínio de ênclise com as demais preposições. Tal fato permite pensar no peso do letramento do Grupo Escolar. Pela cópia ser chave do sistema operado, o aluno pode ter reproduzido esse padrão de escrita.

Porém, não se deve pensar na cópia como reflexo fidedigno do modelo. Assim como a fotografia (KOSSOY, 2009), ela não é isenta do repertório/filtro pessoal e, por isso é passível de comportar variações, as quais são motivadas por razões distintas, abrindo espaço para o conceito de originalidade da cópia. (SCHWARCZ, 2012).

Pode-se pensar nesse conceito atrelado a duas motivações. O primeiro deles tem a ver com o vernáculo e o segundo com a modalidade escrita do português no Brasil. Por mais que se copiasse conteúdos, se o aluno não tivesse um input robusto, reproduziria o vernáculo e, assim, a originalidade da cópia seria marcada por sua gramática internalizada reproduzida espontaneamente. Como, por exemplo, em uma prova de Caligrafia foram encontrados traços do português popular, como a inserção da nasal em mangistratura e o rotacismo (troca do "l" por " $r$ "), provavelmente um vestígio do "r" retroflexo do dialeto caipira: Depois de formado em leis pella univercidade de Coimbra segiu a carreira da mangistratura em Portugar. (Grupo Escolar de Tatuí 1896).

\footnotetext{
${ }^{27}$ A expressão "escritores calígrafos" é usada por A. Cândido para os escritores que tinham preocupação com a linguagem refletida, rebuscada. Trata-se de Monteiro Lobato, que criou sua editora, de Godofredo Rangel, um magistrado, e de Moacir Piza, jornalista. Os três formaram-se em Direito pela Faculdade de Direito do Largo de S. Francisco.
} 
Essa mesma modalidade de cópia pode ser observada em outras disciplinas, como os desenhos dos navios produzidos pelos alunos do $4^{\circ}$ ano do Grupo Escolar de Sorocaba:
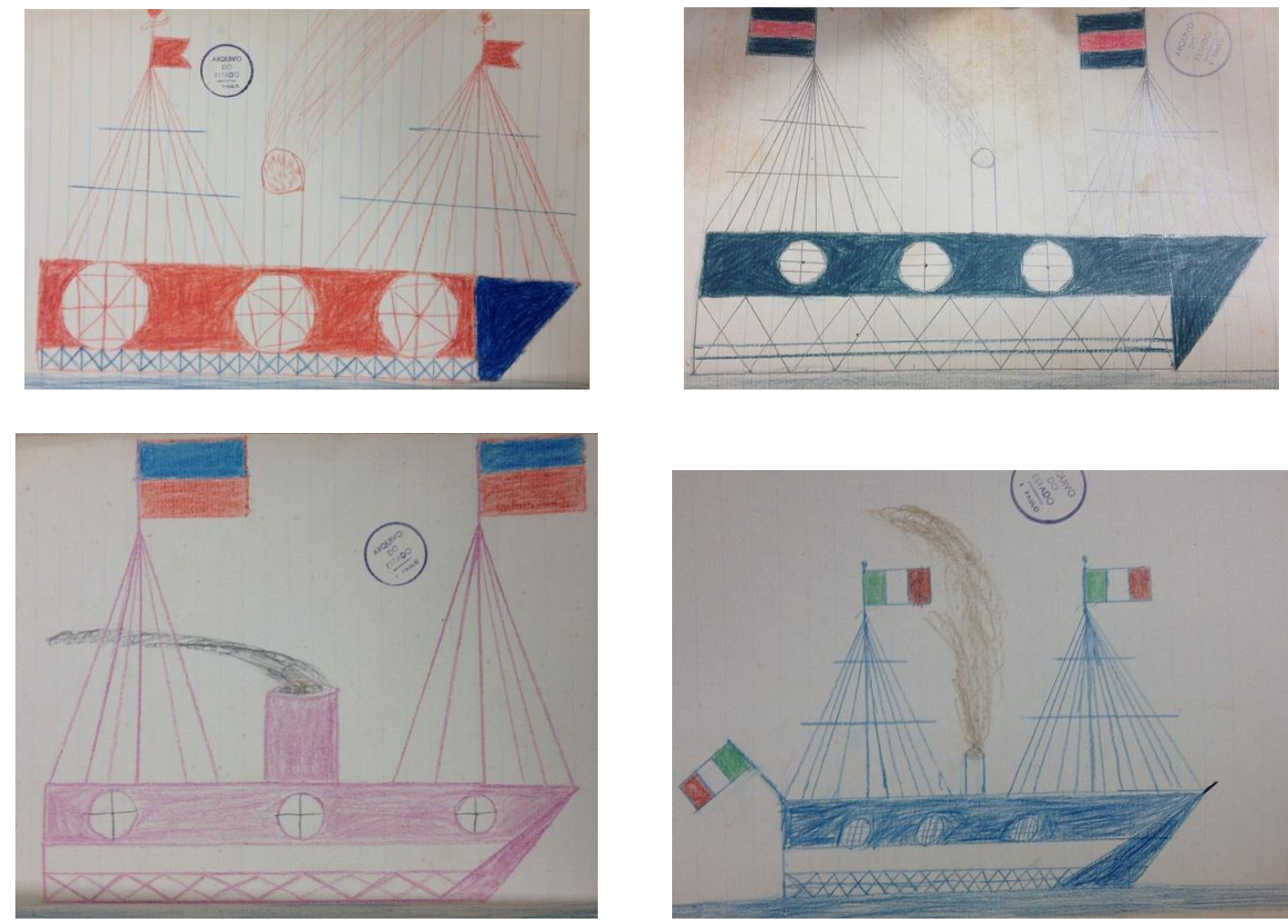

Provavelmente, havia um modelo proposto e a cópia era feita a partir de um filtro pessoal, pois é possível identificar que, nesses desenhos, tendo em vista os demais navios expostos neste trabalho, existe um espaço para a manobra, no qual os alunos vão driblando a técnica.

Nesse caso, a originalidade da cópia é detectada na escolha dos traços a serem salientados. De uma forma geral, os cascos são semelhantes, porém cada aluno explora as cores e as bandeiras utilizadas no topo do mastro real de maneiras diferentes, cada um cria suas próprias portinholas e seus próprios condutos de fumaça. Ao observar e fixar o olhar em mais detalhes, percebe-se também que a direção da fumaça e das bandeiras muda, além de alguns navios trazerem uma bandeira em seu castelo da popa (ponta). 
Supostamente, os alunos desenharam tais navios em uma aula que trabalhou um dos temas emergentes da época, o processo imigratório, entretanto não se pode dizer que algumas escolhas, tais como as cores e as bandeiras, tenham sido feitas de maneira proposital.

A segunda chave de leitura da cópia diz respeito à função social do modelo. No caso da colocação pronominal, a ênclise é recurso estilístico que funciona como marcador distintivo dos republicanos (SANTOS SILVA, 2012). Esse uso foi identificado nas provas de Sorocaba e nos ofícios e nos relatórios de outras cidades.

Dessa forma, a cópia, como processo de reprodução de um modelo dado, aponta variações que têm como pano de fundo um sistema social de normas e valores (ELIAS, 2001) do imaginário republicano paulista, a saber: classificação, hierarquia, civilização, ordem, disciplina, progresso, modernidade e paulistanidade.

Esse sistema também pode ser visto como um repertório de recursos intelectuais disponíveis para a construção de esquemas que englobam noções, argumentos, conceitos, teorias a serem aprendidos e compartilhados pelos alunos dos Grupos Escolares. Dessa forma, as crianças recorreriam a esse repertório de acordo com suas necessidades de compreender e interpretar determinadas situações, reapropriando os conceitos aprendidos a novas circunstâncias. (ALONSO, 2002).

\section{Considerações finais}

Os Grupos Escolares, legítima criação da República, foram adotados como um meio de trabalhar o imaginário popular, os quais, pela fôrma ordeira do novo governo, davam a visibilidade necessária à formatação e à reunião de crianças que simbolizariam a ordem e a união tão cobiçadas e vitais à nação republicana. 
A própria organização dos grupos, marcada pelo princípio das escolas graduadas, já indiciava a tentativa de se instaurar a disciplina almejada a partir da distribuição dos alunos em séries por idade, nível de aprendizagem e estágio de conhecimento, além da disposição espacial em seções feminina e masculina.

Para avançar de uma série para outra, o aluno passava por um sucessivo processo de avaliação que consistia em exames públicos no final do ano letivo e provas das diversas matérias da grade curricular. Essa transição marcava a evolução da criança ao atingir um nível do conhecimento, o que a permitia, teoricamente, aperfeiçoar-se sempre.

Esse sistema contínuo de avaliação tinha por base conteúdos programáticos que se alinhavam aos perfis temáticos de renomadas instituições educacionais do país, tais como, museus etnográficos e institutos históricos e geoográficos, fato que elevava os Grupos Escolares a um projeto intelectual maior.

Por se filiarem a modelos de produção em diálogo com o paradigma evolucionista de civilização e progresso a fim de incutir a noção de classificação e hierarquia no desenvolvimento discente, procurou-se afastar o método de memorização e repetição, adotando o método intuitivo. Entretanto, devido à falta de material didático, tomou-se a cópia como aplicação do método intuitivo e, por meio dela, passou-se a modelar condutas pautadas em seguidas etapas necessárias à evolução.

Nessa busca, a centralidade é o elemento-chave muito bem denotado pelas rosas dos ventos, a partir da qual uma rede de distribuição é organizada. Tal rede se sobrepõe aos mapas de São Paulo, os quais evidenciam um conjunto interconectado de vias fluviais que revelam a propagação civilizatória pelo estado e, por isso, o alinhamento do interior à modernidade e à civilização, além da paulistanidade encerrada na demarcação de fronteiras. 
Todos esses conceitos-chave trabalhados pelos conteúdos programáticos têm a cidade de São Paulo como modelo de civilização e modernidade, fortalecendo o sentimento de paulistanidade e marcando a adesão ao imaginário republicano dos intelectuais paulistas. Entre os elementos culturais que são internalizados no processo educacional dos Grupos Escolares do período, a ênclise é um elemento linguístico que denota a autoafirmação social dos adesionistas ao novo governo. 


\section{Conclusão}

Dos documentos referentes às atividades dos grupos escolares da virada do século XIX para o XX emerge a lassidão do projeto republicano para a educação primária, não obstante fosse a bandeira do novo governo.

Além do agrupamento dos alunos, as inovações no âmbito educacional diziam respeito à seriação do ensino - advento da escola graduada implantada nos grupos - e no método intuitivo como forma de apreensão do conhecimento, em substituição à repetição e memorização.

Apesar dessa atmosfera modernizadora, os ofícios e relatórios analisados evidenciam o desinteresse do Governo pela Instrução Pública, devido à falta de investimento. Há que se observar que, instaurada a República, o governo central não assumiu as rédeas da educação e delegou aos estados a provisão do ensino público, iniciado pelo estado de São Paulo, cujo sistema escolar foi construído com foco na formação de professores e na renovação da metodologia de ensino.

A falta de preocupação não era apenas do governo, mas também dos diretores do grupo que resumiam seus interesses ao aspecto visual dos edifícios, construindo a ideia da escola como vitrine. O importante aqui era a visibilidade que se consolidava pela manutenção e construção dos prédios dos Grupos Escolares, pois as autoridades republicanas dotavam o espaço escolar de identidade para que a escola cumprisse sua função de condicionar o aluno a obter determinada formação sociopolítica.

As reclamações encontradas nos documentos permeiam a falta de infraestrutura básica: salas de aula que comportassem a divisão dos alunos por idade e nível de conhecimento; material escolar, objetos e utensílios adequados para se trabalhar o método intuitivo implantado; e até mesmo professores qualificados, pois a maioria 
vinha transferida das escolas isoladas sem nenhum preparo para trabalhar com os novos sistemas de ensino.

Assim, o projeto de expansão das escolas públicas primárias obteve efeito contrário ao esperado e desejado, pois sem o adequado planejamento, mostrou-se sem estrutura e preparo necessários para expandir a Instrução Pública primária com qualidade. Como possuíam um objetivo único nesse projeto, os Grupos Escolares foram mais uma estratégia para se trabalhar o imaginário popular, dando visibilidade apenas à formatação de crianças representantes da ordem republicana.

Dentro desse ideário sócio-político republicano, em que se vai impondo um sistema de normas e valores - ordem, modernização, paulistanidade etc., a análise linguística pode contribuir para detectar a adesão ao novo sistema. Neste trabalho analisamos a colocação pronominal como índice da aderência dos grupos ao padrão linguístico dos intelectuais republicanos.

Com efeito, no período três modelos de colocação pronominal estavam em jogo, o que se detecta no contexto das infinitivas preposicionadas: o sistema português que optava pela restrição da ênclise usada tão somente na presença da preposição $a$, o sistema vernacular que privilegiava a próclise ostensiva, e o padrão usado pela elite sócio-política que investiu pesadamente na ênclise (OLIVEIRA, 2013, 2014a e 2014b) e pelos intelectuais republicanos paulistas (SANTOS SILVA, 2012).

As amostras analisadas são permeadas pela ênclise majoritária, o que permite dizer que, à expansão dos grupos, correlaciona-se a difusão do modelo linguístico, seja na região do Vale do Paraíba seja no Oeste Velho Paulista. Não se deve esquecer que o período foi marcado pelo adensamento populacional do Oeste Paulista devido à necessidade de busca de terras férteis para a plantação do café. Grandes proprietários 
das lavouras que, vitimizados pela decadência do Vale do Paraíba, se deslocaram paro o oeste.

Para escoamento dos grãos e para mobilizar essa transitoriedade de pessoas entre os espaços conquistados, criou-se uma malha ferroviária que se ramificou pelas entranhas do interior paulista. A ênclise aparece nos documentos das cidades distribuídas pelas rotas paulistas principais. A próclise se firmou em Itapira e Serra Negra, cidades próximas às rotas paulistas principais, mas também às rotas mineiras.

As cidades de Mococa e São José dos Campos fazem uso da ênclise, mas aplicam-lhe diferentes valores. Na cidade do Vale do Paraíba a ênclise ocorre em contexto de verbos comunicativos e sinaliza uma saudação, um bater continência; na cidade do Oeste Paulista a ênclise aparece em contexto de verbos propositivos e é usado simbolicamente como voz de comando para o cumprimento da proposta. Apesar das diferenças, em ambos os casos a ênclise está associada a instruções dos exercícios militares.

Como forma de colaborar para que essa simbologia republicana se mantivesse e se enraizasse nas tradições populares, Mococa se comprometia com as propostas republicanas por ordens e comandos, já São José dos Campos se valia do rito cerimonioso da saudação. Assim, a ênclise diferenciava o usuário engajado no sistema de normas e valores republicanos ao mesmo tempo em que ampliava o fosso entre as classes sociais que não se beneficiavam do processo escolar de aquisição do valor distintivo da ênclise.

Se a filiação ao sistema de normas do imaginário republicano é observada pelo uso do padrão linguístico vinculado aos republicanos, verificamos que, por se filiarem também ao paradigma evolucionista de civilização e progresso, os Grupos Escolares tentavam incutir a noção de classificação e hierarquia no desenvolvimento discente. 
Devido à ausência de material didático, passou-se a fazer uso da cópia como aplicação do método intuitivo e, por meio dela, eram modeladas condutas pautadas em seguidas etapas necessárias à evolução.

Entre os valores veiculados, a ordem e a hierarquia estavam presentes no conteúdo programático de todas as disciplinas. Nas provas de desenho a centralidade se torna elemento-chave muito bem representado pelas rosas dos ventos, a partir da qual uma rede de distribuição se organiza. Essa rede também aparece nas provas de Geografia no conjunto interconectado de vias fluviais, exposto nos mapas de São Paulo, e revela a propagação civilizatória pelo estado. Explora-se assim a ideia de que as regiões interioranas se alinham à modernidade e à civilização da cidade paulista, fato que encerra a paulistanidade na demarcação de fronteiras.

Entre os elementos culturais que são internalizados no processo educacional dos Grupos Escolares do período, a ênclise é um elemento linguístico que denota civilização e, portanto, autoafirmação social dos adesionistas ao novo governo. A função social da ênclise pelos grupos de Mococa e de S. José dos Campos que a associam aos ritos dos exercícios militares deixa em evidência essa aderência. 


\section{Referências Bibliográficas}

ALONSO, Ângela. Idéias em movimento: a geração 1870 na crise do Brasil-Império. São Paulo: Paz e Terra, 2002.

ALONSO, Ângela. O Positivismo de Luís Pereira Barreto e o Pensamento Brasileiro no Final do Século XIX. Disponível em: <www.iea.usp.br/artigos>. 1995.

BOSI, Alfredo. O positivismo no Brasil: uma ideologia de longa duração. Disponível em: <www.academia.org.br>.

BOURDIE, Pierre. Novas reflexões sobre a dominação masculina. In: LOPES, Marta; MEYER, Dagmar; WALDON, Vera. (orgs). Gênero e saúde. Porto Alegre: Artes Médicas, 1996: 28-40. . A dominação masculina. Rio de Janeiro: Bertrand, 1999.

BUFFA, Ester. Arquitetura e educação: organização do espaço e propostas pedagógicas dos grupos escolares paulistas - 1893/1971. São Carlos: EdUFSCar, 2002.

CARNEIRO RIBEIRO, E. Serões grammaticaes ou Nova Grammatica Portugueza. Salvador: Livraria Progresso Editora, 1890.

CARDOSO, Maria Angélica. Escola isoladas paulistas: um modelo desajustado? Revista Linhas, Florianópolis, v. 14, n. 27, jul./dez. 2013: 201-233.

CARVALHO, José Murilo de. Os bestializados: o Rio de Janeiro e a República que não foi. São Paulo: Companhia das Letras, 1987.

A formação das almas: o imaginário da República no Brasil. São Paulo: Companhia das Letras, 1990.

CHAVES DE MELO, Gladstone. Alencar e a Língua Brasileira. Rio de Janeiro: Conselho Federal de Cultura, 1972.

COAN, Giovanna Ike. As construções-se em anúncios publicitários de revistas paulistanas. Dissertação de mestrado. FFLCH/USP. 2011.

COSTA, Ângela Marques da. \& SCHWARCZ, Lilia Moritz. 1890-1914: No tempo das certezas. São Paulo: Companhia das Letras, 2000.

COSTA, Emília Viotti da. Da Monarquia à República: momentos decisivos. São Paulo: Editora UNESP, 2010.

ECKERT, Penelope. The meaning of style. Proceedings of the eleventh annual Symposium about Language and Society, Texas Linguistic Forum 47, 2003: 41-53.

ELIAS, Norbert. A sociedade de corte: investigação sobre a sociologia da realeza e da aristocracia da realeza e da aristocracia de corte. Rio de Janeiro: Zahar, 2001. 
FERREIRA, Nilce Vieira Campos. O texto oficial: aspectos gerais e interpretações. FAZU em Revista, Uberaba, n. 3, 2006: 159-166.

GINZBURG, Carlo. Sinais: raízes de um paradigma indiciário. In: Mitos, emblemas e sinais: morfologia e história. São Paulo: Companhia das Letras, 1989: 143-179.

JORGE, A. G. de Araújo. Rio Branco e as fronteiras do Brasil: uma introdução às obras do Barão do Rio Branco. Brasília: Senado Federal, 1999.

KOSSOY, Boris. Realidades e ficç̧ões na trama fotográfica. São Paulo: Ateliê Editorial, 2009.

LABOV, William. Padrões sociolinguísticos. São Paulo: Parábola Editorial, 2008.

MARCÍlLIO, Maria Luiza. História da escola em São Paulo e no Brasil. São Paulo: Instituto Braudel: Imprensa Oficial do Estado de São Paulo, 2005.

MATTOS, Hebe. A vida política. In: Lilia Moritz Schwarcz. (org.) A abertura para o mundo: 1889-1930. Rio de Janeiro: Objetiva, 2012.

MOREIRA, Júlio. Estudos da Língua Portuguesa, vol.II, Lisboa: Livraria Clássica Editora, 1913.

NAGLE, Jorge. Educação e sociedade na Primeira República. São Paulo: Editora Pedagógica e Universitária, 1989.

OLIVEIRA, Marilza de. Pluricentrismo na arena linguística. In: Augusto Soares da SANTOS SILVA, Amadeu Torres, Miguel Gonçalvez (orgs.) Pluricentric Languages: Linguistic Variation and Sociocognitive Dimensions. $1^{\mathrm{a}}$ ed. Braga: Universidade Católica Portuguesa, 2011: 681-694.

- Colocação pronominal: índice social da elite intelectual. Comunicação apresentada no SINEFIL, UFMS. 2013.

- Colocação pronominal: marca social da diferença. Comunicação apresentada no $62^{\circ}$. Seminário do Grupo de Estudos Linguísticos (GEL), Unicamp/IEL. 2014a.

. Posição dos clíticos no xadrez linguístico da virada do século XX. XVII Congresso Internacional da Associação de Linguística e Filologia da América Latina (ALFAL), UFBA. 2014b.

PAGOTTO, Emilio Gozze. Norma e condescendência: ciência e pureza. In: Língua e Instrumentos Linguísticos. Campinas: Pontes Editora/HIL, 1998: 49-68.

Rui Barbosa e a crise normativa brasileira. In: D. Callou e A. Barbosa (orgs.) A norma brasileira em construção: cartas a Rui Barbosa (1886 a 1899). Rio de Janeiro. Fundação Casa de Rui Barbosa, 2011: 105-166.

PEROSA, Graziela Serroni. A aprendizagem das diferenças sociais: classe, gênero e corpo em uma escola para meninas. Cadernos Pagu (26), Jan./Jun. de 2006: 87-111. 
REGO, José Lins do. Menino de Engenho. Rio de Janeiro: José Olympio, 2012.

SANTOS SILVA, Hosana dos Santos. O Lugar da língua na São Paulo transformada: os usos linguísticos dos intelectuais republicanos paulistas. Tese de doutorado. FFLCH/USP. 2012.

SAVIANI, Demerval. O legado educacional do longo século XX brasileiro. In: Demerval Saviani et al. O legado educacional do século XX no Brasil. Campinas: Autores associados, 2005.

SCHWARCZ, Lilia Moritz. O espetáculo das raças: cientistas, instituições e questão racial no Brasil - 1870-1930. São Paulo: Companhia das Letras, 1993.

População e sociedade. In: Lilia Moritz Schwarcz. (org.) A abertura para o mundo: 1889-1930. Rio de Janeiro: Objetiva, 2012.

SCHEI, Ane. A colocação pronominal do português brasileiro. A língua literária contemporânea. São Paulo: Humanitas, 2013.

SEVCENKO, Nicolau. Literatura como missão. São Paulo: Companhia das Letras, 2003.

SOUZA, Rosa Fátima de. Lições da Escola Primária. In: Demerval Saviani et al. $O$ legado educacional do século XX no Brasil. Campinas: Autores associados, 2005.

SUMMERSON, John. A linguagem clássica da arquitetura. São Paulo: Martins Fontes, 1982.

TARALLO, Fernando. Diagnosticando uma gramática brasileira: o português d'aquém mar ao final do século XIX. In: Ian Roberts e Mary Kato. (orgs.) O Português Brasileiro: uma viagem diacrônica. Campinas: EDUNICAMP, 1993: 69-105.

VALDEMARIN, Vera Teresa. Estudando as lições de coisas: análise dos fundamentos filosóficos do método de ensino. Campinas: FAPESP: Autores Associados, 2004.

VIDAL, Diana Gonçalves Vidal. Cultura e práticas escolares: uma reflexão sobre documentos e arquivos escolares. Campinas: Autores Associados, 2005. 


\section{Anexos}

Tabela 1 - Relação dos Grupos Escolares pesquisados

\begin{tabular}{|c|c|c|}
\hline GRUPO & CIDADE & DIRETOR \\
\hline $\begin{array}{c}\text { Grupo Escolar Edmundo } \\
\text { Trench }\end{array}$ & Avaré & Henrique Gaspar Midom \\
\hline $\begin{array}{c}\text { Grupo Escolar Dr. Jorge } \\
\text { Tibiriçá }\end{array}$ & Bragança Paulista & Leonidia Furquim Leme \\
\hline $\begin{array}{c}1^{\circ} \text { Grupo Escolar de } \\
\text { Campinas }\end{array}$ & Campinas & Christian Vockarz \\
\hline $\begin{array}{c}2^{\circ} \text { Grupo Escolar de } \\
\text { Campinas }\end{array}$ & Campinas & $\begin{array}{c}\text { Pedro Thomas Paulo de } \\
\text { Oliveira }\end{array}$ \\
\hline $\begin{array}{c}\text { Grupo Escolar Dr. Almeida } \\
\text { Vergueiro }\end{array}$ & Espírito Santo do Pinhal & Ulysses Terral \\
\hline $\begin{array}{c}\text { Grupo Escolar Dr. Flaminio } \\
\text { Lessa }\end{array}$ & Guaratinguetá & Joaquim Vieira de Campos \\
\hline $\begin{array}{c}\text { Grupo Escolar Dr. Júlio de } \\
\text { Mesquita }\end{array}$ & Itapira & $\begin{array}{c}\text { Glycério Bueno da Costa } \\
\text { Barrios }\end{array}$ \\
\hline $\begin{array}{l}\text { Grupo Escolar Dr. Cesário } \\
\text { Motta }\end{array}$ & Itu & André Roiz de Alckimin \\
\hline Grupo Escolar Cel. Vaz & Jaboticabal & $\begin{array}{l}\text { Benedito de Azevedo } \\
\text { Marques Júnior }\end{array}$ \\
\hline $\begin{array}{c}\text { Grupo Escolar Cel. Siqueira } \\
\text { Moraes }\end{array}$ & Jundiaí & Raphael de Moraes Vieira \\
\hline $\begin{array}{c}\text { Grupo Escolar Dr. Augusto } \\
\text { Cézar }\end{array}$ & Leme & Joaquim Antônio Sadeira \\
\hline $\begin{array}{c}\text { Grupo Escolar Cel. Flaminio } \\
\text { Ferreira }\end{array}$ & Limeira & $\begin{array}{c}\text { Benedicto Estevam dos } \\
\text { Santos }\end{array}$ \\
\hline $\begin{array}{c}\text { Grupo Escolar Gabriel } \\
\text { Prestes }\end{array}$ & Lorena & $\begin{array}{c}\text { João Pereira de Souza } \\
\text { Penna }\end{array}$ \\
\hline $\begin{array}{c}\text { Grupo Escolar Barão de } \\
\text { Monte Santo }\end{array}$ & Mococa & Cherubim Sampaio \\
\hline
\end{tabular}




\begin{tabular}{|c|c|c|}
\hline Grupo Escolar Cel. Venâncio & Mogi Mirim & $\begin{array}{c}\text { Alfredo Rodrigues do } \\
\text { Prado }\end{array}$ \\
\hline $\begin{array}{c}\text { Grupo Escolar Moraes de } \\
\text { Barros }\end{array}$ & Piracicaba & $\begin{array}{c}\text { Alfredo Maria de } \\
\text { Albuquerque Freitas }\end{array}$ \\
\hline Grupo Escolar de Piracicaba & Piracicaba & $\begin{array}{c}\text { Militão Affonso de } \\
\text { Azevedo }\end{array}$ \\
\hline $\begin{array}{l}\text { Grupo Escolar Dr. José } \\
\text { Guimarães Júnior }\end{array}$ & Ribeirão Preto & Mário Antônio de Sousa \\
\hline $\begin{array}{c}\text { Grupo Escolar de Ribeirão } \\
\text { Preto }\end{array}$ & Ribeirão Preto & $\begin{array}{l}\text { Orestes de Oliveira } \\
\text { Guimarães }\end{array}$ \\
\hline $\begin{array}{c}\text { Grupo Escolar de São José } \\
\text { dos Campos }\end{array}$ & São José dos Campos & Licinio Leite Machado \\
\hline $\begin{array}{c}\text { Grupo Escolar Cel. } \\
\text { Domingues de Castro }\end{array}$ & São Luiz do Paraitinga & Ayres Amansio de Alonso \\
\hline $\begin{array}{c}\text { Grupo Escolar Dr. Augusto } \\
\text { Reis }\end{array}$ & São Manoel do Paraíso & Possydomio Sallez \\
\hline $\begin{array}{c}\text { Grupo Escolar da Alameda } \\
\text { do Triunfo }\end{array}$ & São Paulo & José Carlos Dias \\
\hline Grupo Escolar do Brás & São Paulo & João F. Pinto e Silveira \\
\hline $2^{\circ}$ Grupo Escolar do Brás & São Paulo & João Mário de Freitas Brito \\
\hline $3^{\circ}$ Grupo Escolar do Brás & São Paulo & Arthur Goulart Penteado \\
\hline Grupo Escolar da Liberdade & São Paulo & José Pereira Bicudo Filho \\
\hline Grupo Escolar Maria José & São Paulo & Elisa de Macedo \\
\hline Grupo Escolar da Mooca & São Paulo & G. Álvares Correa \\
\hline Grupo Escolar do Pari & São Paulo & Justiniano Vianna \\
\hline $\begin{array}{c}\text { Grupo Escolar de Santa } \\
\text { Efigênia }\end{array}$ & São Paulo & Olympio Vieira \\
\hline $\begin{array}{c}\text { Grupo Escolar Dr. } \\
\text { Bernardino de Campos }\end{array}$ & São Roque & Júlio Cézar de Silveira \\
\hline Grupo Escolar de São Simão & São Simão & Avério de Castro \\
\hline
\end{tabular}




\begin{tabular}{|c|c|c|}
\hline $\begin{array}{c}\text { Grupo Escolar de Serra } \\
\text { Negra }\end{array}$ & Serra Negra & João Augusto de Toledo \\
\hline Grupo Escolar de Tatuí & Tatuí & Eduardo Rággio Coimbra \\
\hline Grupo Escolar de Taubaté & Taubaté & Arthur Glória \\
\hline
\end{tabular}

Tabela 2 - Colocação pronominal por tipo de preposição

\begin{tabular}{|c|c|c|c|c|c|}
\hline & $\mathrm{A}$ & $\mathrm{DE}$ & $\mathrm{EM}$ & PARA & POR \\
\hline PRÓCLISE & $12,5 \%$ & $33 \%$ & $0 \%$ & $12 \%$ & $0 \%$ \\
& $(3 / 24)$ & $(27 / 82)$ & $(0 / 4)$ & $(3 / 26)$ & $(0 / 3)$ \\
\hline \multirow{2}{*}{ ÊNCLISE } & $87,5 \%$ & $67 \%$ & $100 \%$ & $88 \%$ & $100 \%$ \\
& $(21 / 24)$ & $(55 / 82)$ & $(4 / 4)$ & $(23 / 26)$ & $(3 / 3)$ \\
\hline
\end{tabular}

Tabela 3 - Colocação pronominal por tipo de pronome

\begin{tabular}{|c|c|c|c|c|c|c|}
\hline & ME & SE & LHE & (O/A $)$ & NOS & VOS \\
\hline PRÓCLISE & $33 \%$ & $11 \%$ & $0 \%$ & $8 \%$ & $0 \%$ & $32 \%$ \\
& $(1 / 3)$ & $(3 / 28)$ & $(0 / 3)$ & $(3 / 37)$ & $(0 / 1)$ & $(25 / 78)$ \\
\hline \multirow{2}{*}{ ÊNCLISE } & $66 \%$ & $89 \%$ & $100 \%$ & $92 \%$ & $100 \%$ & $68 \%$ \\
& $(2 / 3)$ & $(25 / 28)$ & $(3 / 3)$ & $(34 / 37)$ & $(1 / 1)$ & $(53 / 78)$ \\
\hline
\end{tabular}

